Universidad de Lima

Facultad de Comunicación

Carrera de Comunicación

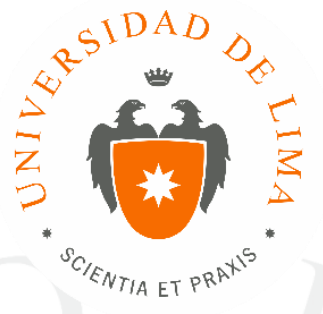

CINE DEBATE: PROYECTO

\title{
MULTIPLATAFORMA QUE BUSCA LA \\ PROMOCIÓN, DIFUSIÓN, EXHIBICIÓN Y \\ DISCUSIÓN DEL CINE PERUANO
}

\section{AUTOGESTIONADO}

Trabajo de Suficiencia Profesional para optar el Título Profesional de Licenciado en Comunicación

\section{Tatiana Novoa Osorio}

Código 20080713

\section{Asesor}

José Carlos Cabrejo

Lima - Perú

Julio de 2017 


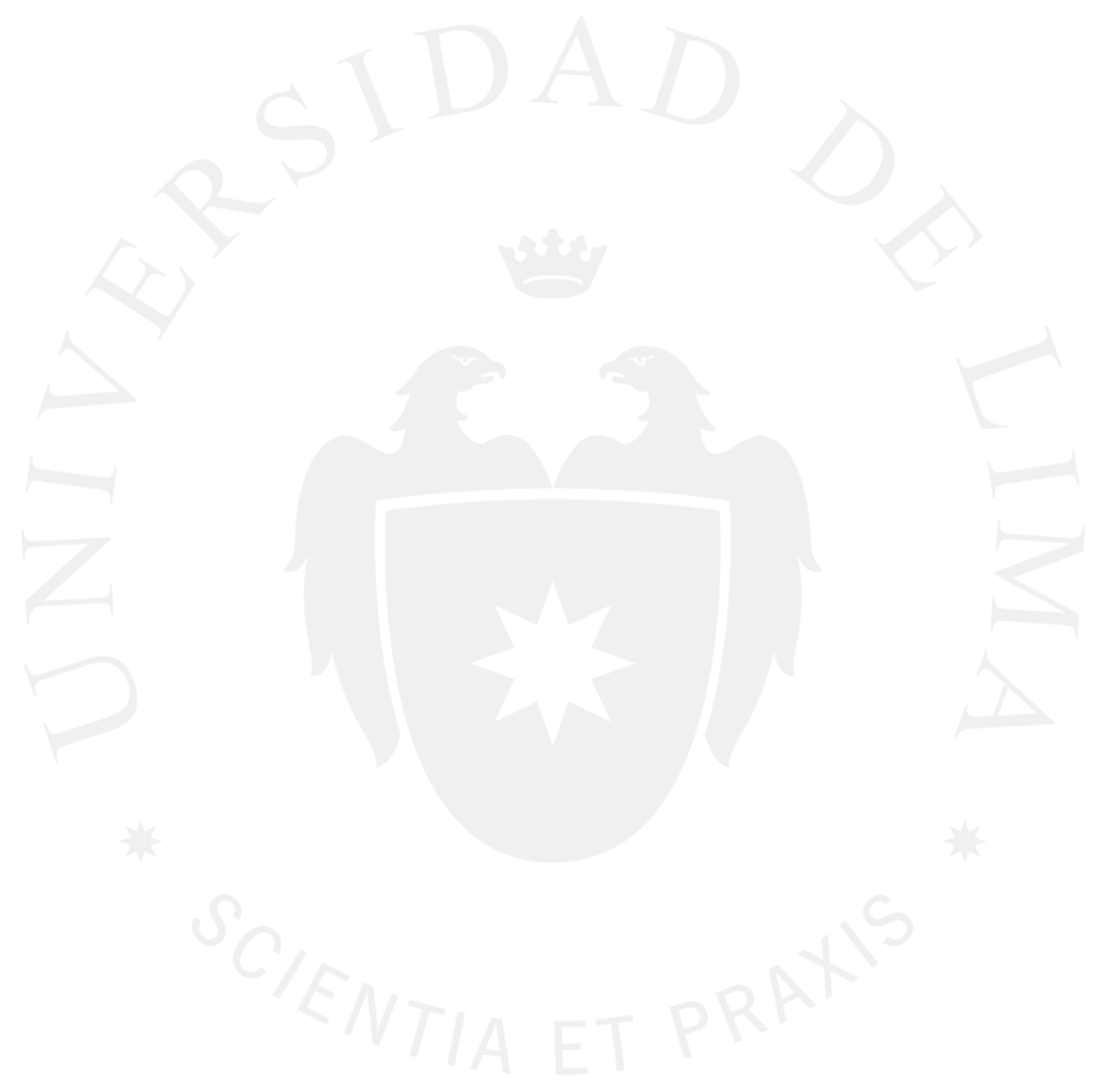




\section{CINE DEBATE: PROYECTO}

\section{MULTIPLATAFORMA QUE BUSCA LA \\ PROMOCIÓN, DIFUSIÓN, EXHIBICIÓN Y \\ DISCUSIÓN DEL CINE PERUANO}

AUTOGESTIONADO 
"El cineclubismo en el Perú se da bajo el contexto social que se vivía durante los años 66 y 69. En ese entonces, Lima era parte de un fenómeno de difusión cultural, habían encontrado en el cine al medio ideal",

-Atilio Bonilla

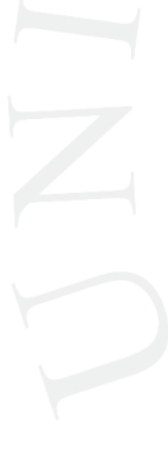

${ }^{1}$ Entrevista al profesor de Cinematografía y encargado del Cine Club en la facultad de Letras de la UNMSM, Atilio Bonilla. 
Tabla de contenidos

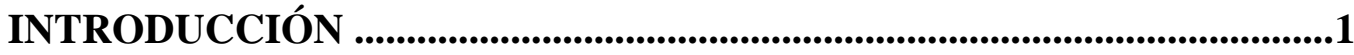

CAPÍTULO I: CAUSAS..................................................................................3

CAPÍTULO II: DESCRIPCIÓN DEL TRABAJO .......................................8

CAPÍTULO III: FUNDAMENTACIÓN CONCEPTUAL .............................12

3.1 ¿En qué consiste el proyecto Cine Debate? ............................12

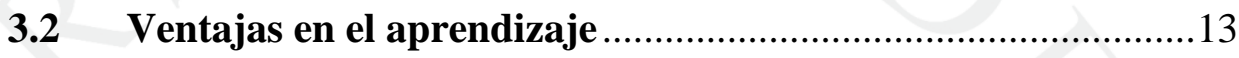

3.3 Ventajas en lo personal ….................................................... 17

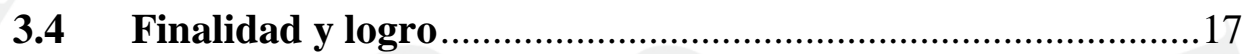

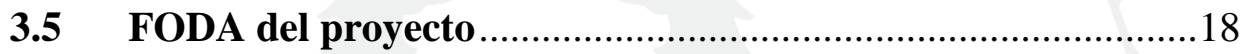

CAPÍTULO IV: TÉCNICAS DE INVESTIGACIÓN.......................................20

4.1 Entrevistas a profundidad (método cualitativo) ….................21

4.2 Respuestas a encuestas con preguntas abiertas (método

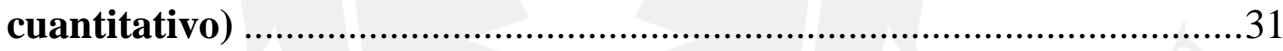

4.3 Respuestas a encuestas con preguntas abiertas (método

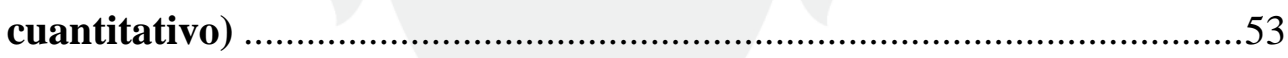

4.4 Encuestas con preguntas abiertas (método cuantitativo) .......58

4.5 Observación natural (método cualitativo).............................63

CAPÍTULO V: CINE DEBATE E INDECOPI ...............................................70

CAPÍTULO VI: CINE DEBATE Y LA GESTIÓN CULTURAL .................72

CAPÍTULO VII: CINE DEBATE Y LOS FESTIVALES INTERNACIONALES 77

CAPÍTULO VIII: SOSTENIBILIDAD DEL PROYECTO ..............................79

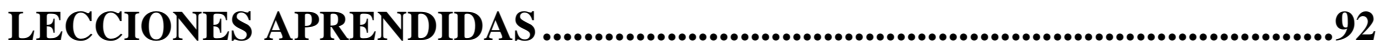

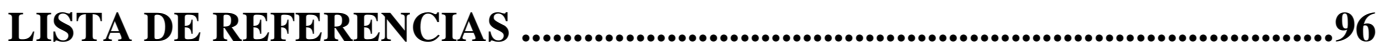




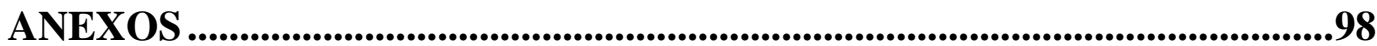




\section{Lista de figuras}

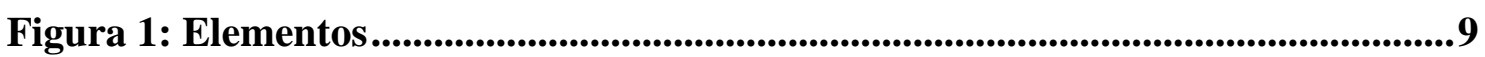

Figura 2: FODA de Cine Debate ..........................................................................19

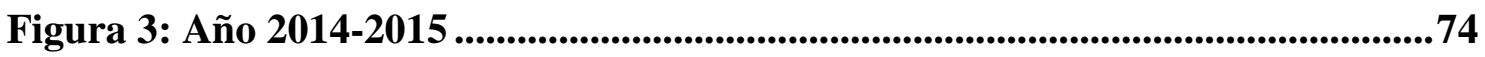

Figura 4: Año 2016 ................................................................................................... 75

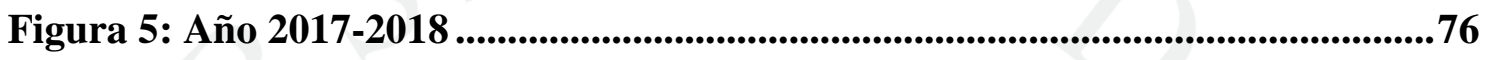

Figura 6: Año 2014: I Edición (abril-junio) .............................................................79

Figura 7: Año 2014: II Edición (noviembre-diciembre)...........................................81

Figura 8: Año 2015: III Edición (septiembre-diciembre) .....................................83

Figura 9: Año 2015: Cine Debate y el Festival Internacional del Nuevo Cine

Latinoamericano de la Habana .............................................................................8

Figura 10: Año 2016: IV Edición (enero-septiembre) ..............................................87

Figura 11: Año 2017: V Edición (noviembre) .....................................................................89

Figura 12: Año 2018: VI Edición (Bulgaria, mayo-julio)................................................90 


\section{Introducción}

CINE DEBATE es el trabajo teóricamente fundamentado por la artista y comunicadora Tatiana Novoa Osorio. Presenta como fundamento, experiencias, investigaciones, estudios cualitativos y cuantitativos, así como exploraciones, con el fin de establecer un proyecto destinado a la exhibición, difusión, promoción y debate del cine peruano; autogestionado con bases y estrategias de gestión cultural, lo cual ha permitido que desde el año 2014 a la actualidad se vuelva sostenible y se mantenga vigente.

El proyecto no presenta antecedentes, responde a una necesidad actual, generada por el surgimiento de un cine peruano con características inéditas. Tal es la oportunidad, que se intenta aprovecharla mediante la promoción y difusión de la creatividad cinematográfica proveniente de realizadores jóvenes, a través de la exhibición de sus obras y el debate sobre ellas. Busca también, ampliar el conocimiento del cine alternativo, independiente y de autor que se hace en la actualidad.

El proyecto Cine Debate, desde sus inicios, intentó vincular a los cineastas y a un público nuevo, aún no expuesto a formas narrativas y estilísticas que difieren del cine peruano del pasado. Para lograrlo, los directores presentan sus propias películas, donde ellos mismos realizan intervenciones a través del conversatorio. Dichas intervenciones son grabadas y subidas a redes sociales. Esto genera una conversación sobre lo visto y se debate no solo sobre las películas, sino también sobre las condiciones de su producción, entre otros temas. Al mismo tiempo, se busca crear nuevos públicos para nuevas películas, promoviéndolos en el sector universitario, pero 
también en públicos distintos, vecinos de las zonas donde se exhiben las películas o que han sido convocados por la prensa o las redes sociales. 


\section{Capítulo I:}

\section{Causas}

Las causas del proyecto respondieron a las siguientes interrogantes, las cuales han sido respondidas luego de su realización, a lo largo de tres años de trabajo:

\section{1. ¿La promoción y difusión del cine a través del debate mejoraría el conocimiento}

\section{sobre el cine alternativo, independiente y de autor peruano?}

- Sí. El público asistente a las ediciones de Cine Debate no solo miraba las proyecciones, sino que también conversaba sobre estas, comentaba entre ellos y con otras personas, en consecuencia, se iba formando una bola de nieve de promoción y difusión hacia estas nuevas propuestas alternativas, independientes y de autor, que realizan cineastas peruanos, que actualmente es una característica resaltante del proyecto en sí.

- $\quad$ El debate promueve la sinergia de conocimientos y según el fallecido psicoanalista David Paul Ausubel, esta sinergia asegura el aprendizaje significativo. "El aprendizaje significativo parte de un conocimiento previo que se mezcla con uno nuevo para formar uno mejor" (Díaz Barriga \& Hernández Rojas) ${ }^{2}$. En el caso del proyecto, los asistentes vienen con referentes de otros filmes que se asocian con el nuevo filme, de tal manera que generan un conocimiento nuevo y mejor en base a la relación entre ambos. Entonces, el debate permite que se pueda dar

\footnotetext{
${ }^{2}$ Díaz Barriga Arceo, Frida y Gerardo Hernández Rojas. Estrategias docentes para un aprendizaje significativo. Mc Graw Hill, 2da Edición, cap. 2, Constructivismo y Aprendizaje Significativo, 59p.
} 
este intercambio de conocimientos a través de las intervenciones en el posconversatorio entre realizadores y asistentes.

\section{2. ¿Se puede crear un espacio que integre una sinergia de conocimientos sobre la}

\section{película proyectada por parte de sus participantes?}

- Definitivamente, sí se puede hablar de sinergia de conocimientos en este espacio multiplataforma que se ha realizado con Cine Debate, ya que, al agrupar a un público general de distintas realidades sociales y culturales intercambian un vasto conjunto de argumentos y apreciaciones sobre la película. A la vez, se puede asegurar que un filme será visto de distintas miradas, percepciones y formas.

Por ejemplo, habrá participantes que se muestren muy interesados sobre la fotografía, otros sobre la historia en sí, otros sobre la propuesta de arte, otros sobre el contexto polémico-social en el que se podría desarrollar el corto o largometraje, en fin; una serie de mezclas e intercambios de conocimientos sobre un filme proyectado en un mismo espacio.

3. ¿Se podría exhibir cortos y largometrajes de realizadores peruanos en espacios que buscan la preservación de la experiencia cinematográfica y a la vez, la participación directa de sus realizadores, a través de conversatorios?

- $\quad$ Si bien es cierto, no se puede negar al auge de las websites que permiten el visionado de manera barata o gratuita y a la vez, individualizada, de una serie de propuestas de cine independiente, alternativo y de autor a escala mundial; aún no se pierde y no se devalúa la experiencia cinematográfica de ver proyecciones. Es más, la exhibición de este tipo de cine independiente, alternativo y de autor que se vive en el Perú no cuenta con espacios tangibles de exhibición, los únicos son los cineclubs, pero casi muy pocos como cine Tertulia, cine Galpón, 
entre otros, proyectan filmes nacionales contemporáneos. Por ello, Cine Debate encontró en la multiplataforma la mejor opción, ya que cuenta con un espacio físico y un espacio en línea.

Por otro lado, el conversatorio entre los realizadores y el público asistente genera la confluencia de conocimientos, la retroalimentación, el "tuiteo" inmediato (como si estuviéramos en twitter, pero en vivo y en directo), la comunicación horizontal, el intercambio de datos, pareceres, ideas, lazos de relaciones (muchos de los asistentes desean hacer cine y se agrupan para crear proyectos juntos), entre otros. En síntesis, se crea una serie de ventajas entre todos cuando somos parte de la experiencia Cine Debate.

\section{4. ¿La experiencia cinematográfica sigue siendo la más placentera para ver un filme, o} ha sido desplazada por las páginas web que nos ofrecen descargar y ver los filmes desde nuestra computadora portátil de una manera más personal?

- En la actualidad, se perciben los efectos de la web 3.0 y el fenómeno de la trasmedia como consecuencia de la modernidad líquida que se vive en relación a la inmediatez de la información y su difusión. Los asistentes ven uno de los trabajos audiovisuales proyectado en el evento y automáticamente lo están comentando y compartiendo con sus amigos o sus páginas favoritas del ciberespacio. No obstante, aún se va al cine, ya sea a los estrenos de películas u otras películas que nos ofrece la cartelera o a pasar un momento ameno, entre otras razones.

Según informes de (IPSOS APOYO, 2012) ${ }^{3}$ una de las actividades de entretenimiento y diversión que ha crecido desde el año 2009 es "ir al cine”, dato respaldado por aproximadamente 32,8 millones de espectadores de cine en el informe del año pasado. Esto demuestra que la

\footnotetext{
${ }^{3}$ Ipsos Apoyo. Informes de mercado. Lima, Perú, 2012.
} 
experiencia cinematográfica no pasa de moda y su finalidad de entretener no ha cambiado, todos quieren ver historias, ¿por qué no ver más de este otro tipo de cine que surge en las nuevas generaciones con un estilo independiente, alternativo y de autor? Hay público, lo que no hay son espacios adecuados de exhibición, apoyo hacia proyectos independientes y/o autogestionados por parte del Estado y su respectiva difusión; es ahí donde Cine Debate encuentra su finalidad y poco a poco, su reconocimiento por parte del público asistente y los realizadores peruanos.

5. ¿Qué tan conflictivo puede ser el agrupamiento de opiniones, críticas, sugerencias, apreciaciones y juicios calificativos por parte del público asistente que proviene de distintas realidades, gustos cinematográficos y valoraciones audiovisuales?

- A través de la experiencia del proyecto nunca se ha generado un "conflicto", por el contrario, se genera una confluencia de ideas, pareceres y opiniones por parte de todos los asistentes. Un ejemplo de ello es el siguiente: un estudiante de filosofía que asiste al evento Cine Debate opina sobre el trasfondo del guión y, por otro lado, un fotógrafo analiza la propuesta de iluminación, y a través de estas perspectivas y percepciones distintas hacia un mismo producto cinematográfico, el debate se enriquece.

- Por otro lado, la experiencia del proyecto desmiente las apreciaciones de profesores de la Universidad Nacional Mayor de San Marcos (UNMSM) como Martín Peña, profesor de Literatura Latinoamericana, quién aseguraba que sí puede haber conflicto, debido a que el cine siempre muestra un filme influenciado por una corriente ideológica, política y social determinada, y por ejemplo, los jóvenes del Partido Revolucionario Organizado Democráticamente (PRODE), quienes plantean una inclinación clara de régimen izquierdista, podrán emitir apreciaciones o comentarios que generen gran controversia y el conversatorio 
podría tornarse tenso. En la práctica nunca ha ocurrido esto. Primero, el proyecto fomenta el respeto hacia los comentarios que expresa cada participante en su intervención promoviendo la tolerancia de opiniones. Segundo, hay que destacar que el proyecto maneja un filtro a la hora de seleccionar los filmes que se van a proyectar y visibilizar, basado en el impacto artístico, cultural, social, educativo, creativo e innovador a través del lenguaje y la narrativa audiovisual.

\section{6. ¿Quiénes son los interesados en ver propuestas de cine independiente, alternativo y} de autor de la nueva generación de realizadores peruanos?

- En los tres años que se viene realizando el proyecto Cine Debate cabe destacar que el público asistente es transgeneracional, heterogéneo y aficionado al cine. Lo que los une es la actitud que muestran en cada evento, están dispuestos a ver, apoyar, intervenir, participar, conocer y generar acciones en relación al cine peruano autogestionado, ya sea para su difusión, exhibición o realización. 


\section{Capítulo II:}

\section{Descripción del trabajo}

La creación de este proyecto surge por las siguientes razones:

En primer lugar, el proyecto busca crear un espacio constante, en donde se pueda hablar y aprender más sobre el "otro" cine peruano, el autogestionado (alternativo, independiente y de autor), considerando que la mejor forma es la sinergia e intercambio de pareceres, apreciaciones y comentarios; los cuales generan conocimientos nuevos y a la vez enriquecedores para todos los asistentes a cada evento del proyecto. La experiencia ha probado esto, por tal motivo, surge la elección de las palabras "Cine" y "Debate". En el caso de la primera, se debe a que se deseaba mantener la experiencia cinematográfica. En el caso de la segunda, era la que mejor englobaba lo que se buscaba a la hora de formar una tertulia, luego de cada proyección, un posconversatorio que converge en una sinergia de conocimientos a través de las críticas, apreciaciones, pareceres, sugerencias, comentarios y anécdotas entre realizadores y asistentes. Además, cabe resaltar que esta palabra expresa uno de los objetivos del proyecto, el cual consiste en lograr la retroalimentación en un proceso de comunicación efectiva y de doble vía (siempre hay respuesta a la escucha) entre los cineastas y el público asistente. Para poder lograr dicho objetivo, se pone en práctica la "teoría del aprendizaje significante", elaborada y creada por el psicólogo David Paul Ausubel, la cual nos deja en claro, que siempre la confluencia de dos o varios conocimientos genera uno mejor. 
En segundo lugar, se busca exhibir proyectos de realizadores peruanos, quienes en muchos casos no cuentan con apoyo por parte del Estado para exhibir o difundir sus realizaciones audiovisuales, el proyecto es consciente de dicha problemática. Cine Debate busca darle un proyector, un micrófono un espacio en línea y físico en donde exponer, hablar y discernir sobre sus filmes con otros realizadores y el público asistente.

Figura 1: Elementos

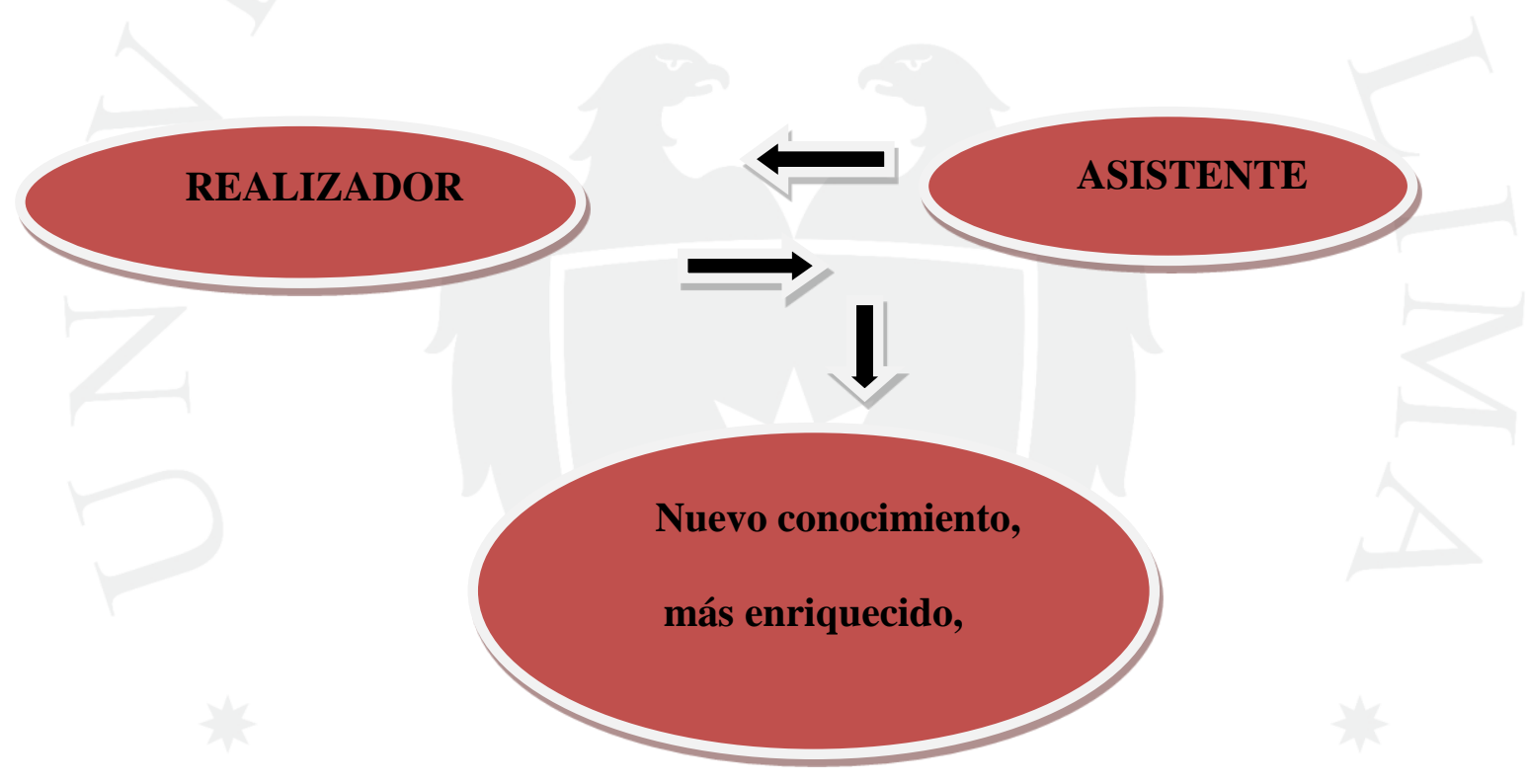

Fuente: Elaboración propia.

Además, es importante mencionar que las características más relevantes del público de Cine Debate son: transgeneracional, cinéfilos, estudiantes, profesores, cineastas, realizadores audiovisuales, comunicadores y educadores. 
En tercer lugar, se busca dar una merecida importancia al cine como un medio que contribuye con la sociedad. Suena para muchos como una utopía, pero sin duda alguna el proyecto Cine Debate entendía que el cine peruano autogestionado, no solo cuenta una historia, también cuenta una etapa de la historia, problemas sociales vigentes, manifestaciones artísticas contemporáneas, entre otros. Es más, para reforzar el argumento motivador del proyecto se toma como referente el artículo 14 de la Constitución Política del Perú: "Los medios de comunicación deben colaborar con el Estado en la educación y en la formación moral y cultural". 4

Finalmente, se elaboraron los objetivos del proyecto:

\section{Objetivo principal:}

- Promoción, difusión, exhibición y discusión del cine peruano autogestionado.

\section{Objetivos específicos:}

- Crear una atmósfera de sinergia de conocimientos sobre el cine nacional generando canales de comunicación entre los realizadores y el público asistente.

- Realizar a través de la gestión cultural una cadena de apoyo a las propuestas de realizadores peruanos que ven el cine como un medio artístico, social, cultural y educativo.

- Ser un proyecto referente de otros futuros proyectos que también deseen crear espacios en donde se difundan más cortometrajes y largometrajes de realizadores peruanos y que, además, sean sostenibles y rentables.

\footnotetext{
${ }^{4}$ Constitución Política del Perú. Medios de comunicación, artículo 14, Lima, Perú, 2014.
} 
- Fomentar la experiencia cinematográfica en base a la participación e intervención de todos los asistentes a los eventos que organiza el proyecto.

Los objetivos fueron puestos a prueba y contrastados, con fines satisfactorios, en las diversas sesiones realizadas en el marco del proyecto Cine Debate. 


\section{Capítulo III:}

\section{Fundamentación conceptual}

\section{1 ¿En qué consiste el proyecto Cine Debate?}

El cineclub es una institución antigua vinculada y destinada a la difusión de la cultura cinematográfica. Nació en Francia en la década de los 20 del siglo XX. En el Perú, tuvo un momento de auge en las décadas de los 50, 60 y 70.

A partir de los años 80, los cineclubes peruanos entran en declive. Salvo la experiencia aislada de El Cinematógrafo, y de algunos empeños culturales impulsados por universidades, los intentos de mantener cineclubes casi desaparecen en nuestro medio, por razones que expondremos más adelante.

En los últimos años, y a raíz de la difusión de las tecnologías digitales, hemos visto el surgimiento de un cine peruano que se produce, distribuye y consume de un modo singular. Son películas autogestionadas, de corto y de largo metraje, que no reciben los apoyos del Ministerio de Cultura ni de los fondos internacionales de producción. Tampoco llegan a las salas de cine comerciales.

En consecuencia, carecen de circuitos de exhibición estables. Se mantienen inéditos o desconocidos para la gran mayoría de espectadores, incluso para los más interesados en las actividades cinematográficas. Este cine alternativo requiere ser visto y discutido. Por eso, 
teniendo en cuenta esa urgencia, se concibe, organiza, registra y se lleva a cabo un proyecto de difusión y discusión de películas peruanas realizadas en los últimos tiempos.

El nombre del proyecto es Cine Debate: Proyecto multiplataforma que busca la promoción, difusión, exhibición y discusión del cine peruano autogestionado y empezó en el mes de abril del 2014, realizando proyecciones de cortometrajes y largometrajes de no ficción y ficción en la sala de la Ventana Indiscreta de la Universidad de Lima. Luego de esas sesiones, Cine Debate se viene realizando en distintas universidades de Lima, espacios culturales alternativos, incluso fue invitado al Festival Internacional del Nuevo Cine Latinoamericano de la Habana, Cuba 2015. Se trata pues, de un proyecto permanente y de alcance continuo. Es el único proyecto de este tipo vinculado con el cine peruano autogestionado.

Cine Debate es sostenible y rentable en base a la estrategia de gestión cultural que presenta. Además de lograr sus objetivos, resalta la comunicación efectiva que genera en sus eventos, entre realizadores y público asistente, basado en un constante intercambio de conocimientos para fomentar un conocimiento nuevo y enriquecedor.

\subsection{Ventajas en el aprendizaje}

La primera ventaja que se vislumbra a través de la experiencia es el nuevo conocimiento adquirido que fomenta Cine Debate. Se debe dejar en claro que, el público asistente proviene de distintas realidades y experiencias educativas disímiles, pero a todos los une y los motiva el interés por aprender y ver más del cine peruano autogestionado. Se genera un intercambio 
valioso de un exquisito bagaje en conocimientos que poseen tanto el público asistente como los realizadores invitados.

Esta consideración se respalda en la teoría del aprendizaje significativo que propone el psicólogo americano David Paul Ausubel.

"Los nuevos conocimientos se incorporan en forma sustantiva en la estructura cognitiva del individuo si solo si el individuo relaciona los nuevos conocimientos con los anteriormente adquiridos; pero también es necesario que el individuo se interese por aprender lo que se le está mostrando.” (Ausubel, 1965).

En otras palabras, la mezcla de los nuevos conocimientos adquiridos que se forman gracias a las opiniones, críticas, divergencias, entre otros, junto a los anteriores terminarán formando un nuevo conocimiento potenciado provechoso para todos los presentes en cada uno de los eventos que organiza Cine Debate, logrando involucrar a todos en el proyecto.

Como segunda ventaja, se fomenta en todos los asistentes de Cine Debate la comunicación interpersonal para aprender más sobre el otro cine autogestionado que se viene llevando a cabo en la actualidad. Según el psicólogo Ángel Marcuello García, la asistencia a Cine Debate genera un conjunto de características favorables en el desarrollo educativo constante sobre cine y sus relaciones con otras disciplinas, como, por ejemplo: fomentar la capacidad de argumentación, síntesis, parafraseo y tolerancia en relación a la discrepancia de opiniones. Además; Marcuello García deja en claro que, este tipo de actividad, la cual fomenta la comunicación interpersonal contribuye en la mejora de la actividad crítica, puesto que comienzan a evitar las generalizaciones a la hora de emitir juicios, opiniones y apreciaciones; y de una manera u otra la 
vuelve efectiva porque en cada conversatorio se aprecia la validación de la escucha activa entre público asistente y realizadores invitados.

La tercera ventaja, para el profesor y doctor en psicología y pedagogía, Valentín Martínez Otero, es importante mencionar el diálogo con fines de intercambio y generador de conocimientos que se vislumbra en el proyecto Cine Debate, puesto que, considera "al diálogo como reconocimiento, cooperación y crecimiento en conjunto", en una entrevista que ofreció en el año 2009 para la revista "El diálogo educativo". Para ello, recomienda que todos los que son parte de una actividad que fomenta el aprendizaje o el "dar a conocer" el "otro" cine peruano opten por usar el diálogo teniendo nociones básicas sobre el tema a tratar; en consecuencia se aprecia que los asistentes de Cine Debate, en estos tres años, disfrutan del cine, quieren aprender y conocer más sobre el mismo y buscan ser parte de una comunidad que lleve a cabo más proyectos de cine nacional, finalmente, después de cada posconversatorio se extraen conclusiones, las cuales enriquecen cada evento de Cine Debate gracias a la sinergia de conocimientos de todos los asistentes.

La cuarta ventaja para el expresidente de CONACINE, Francisco Perla, es que el cine peruano tiene un valor de aprendizaje valiosísimo, ya que, se estaría formando las bases de una cultura más presente de cine peruano. Cine Debate está orientado a reforzar el concepto que se respalda en el artículo 14 de la constitución política del Perú, el cual recae en entender todos los roles que cumple este medio dentro de la sociedad, contribuyendo con la educación, y los que deseen dedicarse a ello deben tenerlo claro. 
En quinto lugar, se debe tener en cuenta las siguientes ventajas en el aprendizaje según el profesor y crítico de cine, Isaac León Frías, y el profesor y guionista, Giancarlo Cappelo, que se han venido dando a lo largo de las sesiones de Cine Debate:

$\checkmark$ Se logra conocer y aprender en mayor medida sobre la historia del cine peruano, dado que, se relaciona con todo tipo de acontecimiento cultural e histórico, a la vez, se reconoce las tendencias en nuestro territorio nacional.

$\checkmark$ Es valioso el conocer otros pareceres y apreciaciones sobre una misma tendencia en el cine nacional, regional y limeño, ya sea, en relación a las sesiones de cine de autor o en relación a las de una época determinada, lo cual fomenta la base de una cultura crítica, gracias a la tolerancia que envuelve cada evento en el posconversatorio. Sin duda alguna, de una u otra manera se fomenta el lenguaje crítico, lo cual permite que, los asistentes se involucren con el lado crítico del cine. Tal es así que, en este punto según la experiencia, los que sacan mayor provecho son los asistentes con una mentalidad abierta al momento de ver otras propuestas y no tanto, la mayoría de cinéfilos, cuyos gustos son muy definidos.

$\checkmark$ Se refuerza la praxis dialógica, lo cual permite una relación horizontal entre todos, basándose en una práctica empática, cordial y respetuosa establecida por un lenguaje explícito y claro. Dejando en claro, que la praxis busca la diferencia de opiniones, pero con igualdad en el trato dialógico.

$\checkmark$ Se deja de lado el discurso socrático que muchas veces envuelve muchos círculos, talleres de cine y algunos cineclubs, los cuales están plagados de burlas o juicios inapropiados. Este proyecto se caracteriza por mostrar en cada una de sus ediciones una 
atmósfera compuesta por un discurso sinérgico, integrando con opiniones, comentarios y pareceres, dejando de lado, cualquier tipo de tono que busque discriminar o jerarquizar.

\subsection{Ventajas en lo personal}

Las ventajas en lo personal que se forman a través de Cine Debate, sin duda alguna, es la red o comunidad de personas que comienzan a relacionarse entre sí, partiendo de un conversatorio hasta un trabajo en conjunto, siempre con un solo eje, el cine. Un claro ejemplo de ello es que la primera casa productora que trabajó con Cine Debate "El Portal Producciones" contrató al cineasta Fernando Montenegro para que trabajen en un proyecto audiovisual juntos, luego de uno de los eventos, otro ejemplo ilustrativo viene a ser la alianza entre la productora "Flores Brothers Producciones" que presentó sus propuestas audiovisuales en dos ediciones del proyecto junto a la empresa "Cinematosis", esta última apoyó a Cine Debate en la difusión en redes y prensa. Estas ventajas se vinieron presentando a lo largo de los tres años que se viene realizando el proyecto y es muy satisfactorio manifestarlo a través de estas líneas.

\subsection{Finalidad y logro}

La finalidad y el logro del proyecto recaen en haber logrado satisfactoriamente los objetivos del proyecto. Entre ellos: la difusión, discusión, exhibición y promoción del cine peruano independiente, alternativo y de autor en circuitos universitarios y culturales. A la vez, se espera lograr una pregnancia nacional e internacional con el proyecto Cine Debate, la cual se ha venido 
llevando a cabo desde el año 2014, puesto que, lo perciben como un medio y espacio para la promoción, difusión, exhibición y discusión de todos los trabajos audiovisuales nacionales (cortometrajes, mediometrajes y largometrajes) que en muchos casos quedan guardados en un USB o disco, ya que, para estos realizadores no les es fácil exhibir, difundir y promocionar sus proyectos audiovisuales, por diversos factores, pero el más urgente es que no cuentan con un lugar físico accesible para la proyección con los respectivos requerimientos técnicos.

Por otro lado, Cine Debate ofrece dentro del posconversatorio que se da luego de cada proyección, discutir la indiferencia y casi nulo apoyo del Estado al cine nacional, fomentándose soluciones basadas en autogestión, estrategias de gestión cultural, marketing y otras alternativas ante la problemática, como alianzas y asociaciones.

Por último, otro logro del proyecto es su constante apoyo a realizadores que hacen un cine no comercial dentro del "mercado nacional", entendiendo que el cine no solo es un medio de entretenimiento, sino que, también es un medio artístico, cultural, social y educativo, que cumple muchos roles invisibles en una modernidad líquida, comercial y ciega de las manifestaciones contemporáneas que surgen al otro lado del "mercado" en el que se encuentra inmerso la sociedad del espectáculo.

\subsection{FODA del proyecto}

Es necesario manejar un análisis FODA (fortalezas y debilidades internas, así como oportunidades y amenazas externas) del proyecto para estar siempre mejorando, corrigiendo y logrando objetivos con las variables involucradas. 
Aquí compartimos el diagnóstico FODA vigente de Cine Debate:

Figura 2: FODA de Cine Debate

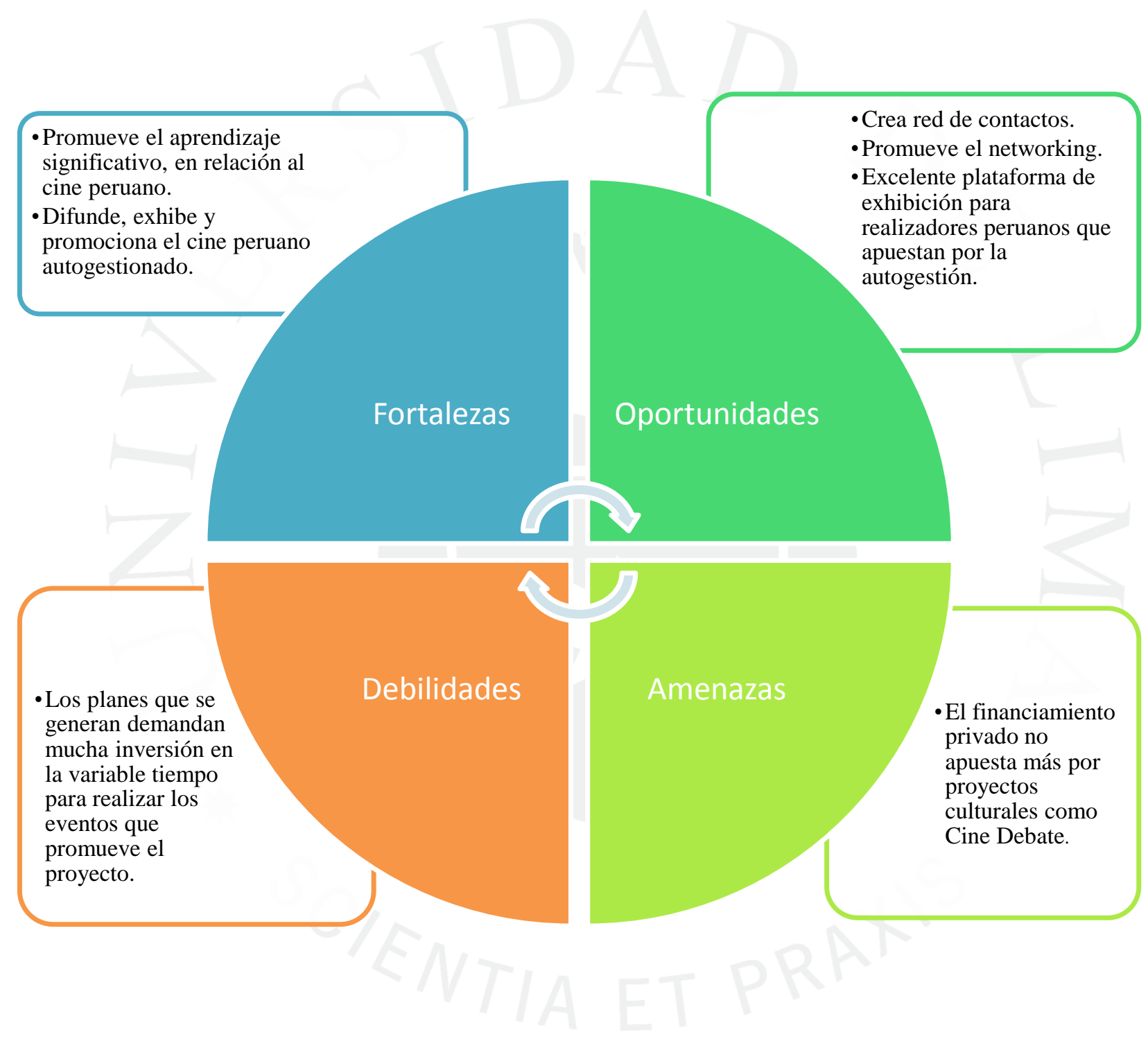




\section{Capítulo IV:}

\section{Técnicas de investigación}

Las técnicas de investigación que se llevaron a cabo para la realización del proyecto se hicieron en base los aportes que brindan los métodos cualitativos y cuantitativos.

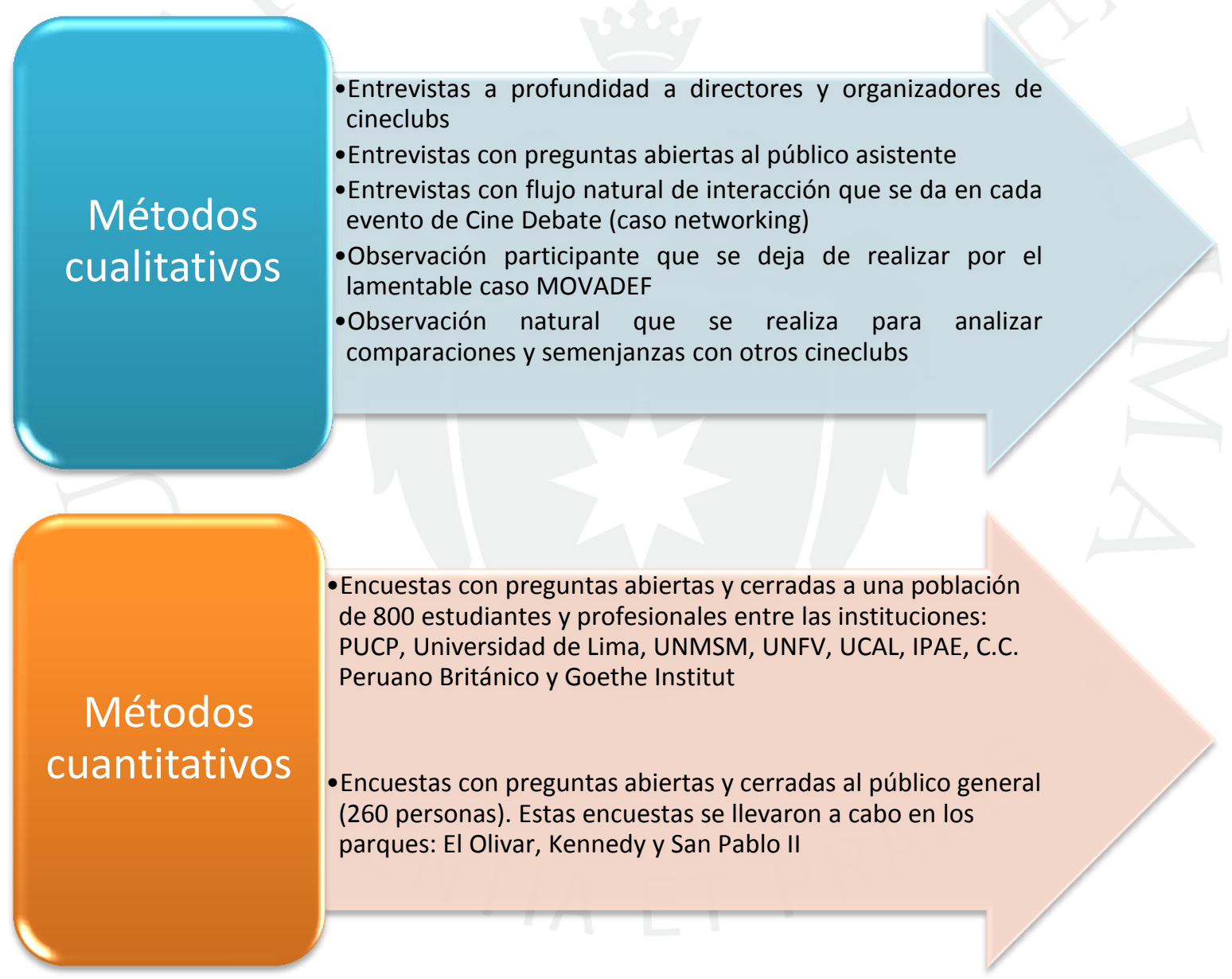

A continuación, algunos de los estudios que se realizaron gracias a ambos métodos. 


\subsection{Entrevistas a profundidad (método cualitativo)}

\section{Entrevista a Atilio Bonilla - Cine Club de la Universidad Nacional Mayor de San Marcos}

Las respuestas que dio el profesor Bonilla en relación a la creación de los primeros cineclubs en Lima fueron sorprendentes. Sumado a ello, la manera de escoger los filmes y los objetivos que espera lograr con el cineclub que preside desde hace más de 20 años, es muy enriquecedor como referente. De la larga entrevista que se realizó, aquí las preguntas más resaltantes:

Tatiana Novoa (TN): ¿Cómo surge la idea de realizar un cineclub?

Atilio Bonilla (AB): Se da bajo un contexto social entre los años 66 y 68 , ya que por esos tiempos Lima vivía un fenómeno de difusión cultural y se había encontrado como medio de tal al cine, es por ello que se forma la Cinemateca, que se refuerza en el hambre que tenían, principalmente, muchos estudiantes de la Universidad Nacional de Ingeniería, Universidad Nacional Mayor de San Marcos (UNMSM), la Universidad Nacional Agraria La Molina y la Pontificia Universidad Católica del Perú por el cine como un constante difusor cultural, ya que se llegaba a conocer otros hechos sociales, otra geografía, otra sociedad, otra historia, entre otros. Estos grupos de estudiantes conseguían pasar las viejas obras del cine universal en locales de San Isidro, el Colegio Champagnat y el Colegio María Reina, como ya dije antes el público asistente en su mayoría era estudiantes, pero también había una fuerte presencia del público intelectual de 
la época. Algo que es cierto es que el Centro de Organización de la Iglesia Católica (COP) auspiciaba el cineclub.

Yo asistí mucho a estos cineclubs y en ese entonces era estudiante de la UNMSM, es así cómo me doy cuenta que se podía llevar a cabo un proyecto similar en salones y qué se podían realizar clases de cine y así se funda el cineclubismo en la UNMSM, aunque siempre se sufrió por la infraestructura, el cine también fomentó ideologías en esta casa de estudios.

TN: ¿Usted está a cargo de este proyecto?

AB: Siempre se ha mantenido a mi cargo, llevo 50 años como profesor de Arte y Comunicación y promoviendo ciclos de Cine Club, pero claro siempre se consulta con el alumnado y se investiga mucho o incluso se comenta con otros colegas sobre la pertinencia y el porqué de transmitir cierta película y otra no.

TN: ¿Los objetivos del proyecto se han mantenido hasta la actualidad?

AB: Sí, siempre fue fomentar cultura, educación y arte.

TN: ¿Quién escoge las películas que se proyectan en el Cine Club?

AB: Yo las escojo, pero bajo un criterio que me ha otorgado la experiencia, para ello tengo que también tener en cuenta si un filme cumple con los requisitos que busco, que como te dije antes es difundir cultura.

Ahora los tiempos han cambiado mucho y esto solo lo hago dos veces al mes, porque el video casero o las nuevas formas de ver cine han cambiado y eso también se debe tomar en cuenta, sumado a los nuevos intereses culturales que han emergido, si ellos ven casi todo, qué debo 
trasmitir o difundir que sea diferente, de ahí es que no se transmiten películas de índole comercial.

TN: ¿Cuáles son las expectativas que presentan los asistentes al Cine Club?

AB: Los alumnos buscan entender y conocer más sobre temas generalmente sociales, es por ello que el género documental es el más aclamado entre ellos.

TN: ¿Cómo procesan los asistentes y/o estudiantes lo que le dicen en el Cine Club?

AB: Se conversa sobre el filme, con un análisis en donde todos participan y todos aprenden viendo, y más que proceso hacia un conocimiento es un conocimiento que lleva a un procesamiento de estar siempre con una disponibilidad de querer ver más, pero de distintas maneras.

TN: ¿Las vocaciones de los asistentes influyen en la programación?

AB: A mi parecer, mucho, porque al ser todos estudiantes en la actualidad, busco siempre una base educativa que se relacione con la puesta en escena. A diferencia de un cine foro, en donde cada uno da su punto de vista y más que una base educativa lo que existe es un conversatorio expositivo.

TN: ¿Qué les parece el desarrollo del Cine Club? ¿Ha sido aceptado satisfactoriamente? ¿Ha habido algunos cambios o se ha mantenido con la idea original?

AB: Sí, hasta hace unos ocho años era muy frecuentado, pero como te dije, ahora las formas de ver cine son cada vez más individualizadas, sí hay asistentes, pero ya no como era antes y si antes tenía un filtro de selección general, ahora es más minucioso. 
Finalmente, quiero mencionar que el profesor Bonilla despide la entrevista diciendo que la idea original de llevar a cabo un proyecto de Cine Debate debe de tener en cuenta a su público que lo conforma un determinado auditorio con ganas de ver un filme en el que converja el arte, la cultura o lo social, lo que no se presenta dentro de las salas con fines comerciales que rigen en la actualidad.

\section{Entrevista a Milton Galopiña-Cine Club Chiclayo}

La entrevista que brindó el director del Cine Club Chiclayo, Milton Galopiña, resultó muy interesante y motivadora porque dejó en claro que este tipo de proyectos pueden llevarse a cabo de manera descentralizada y no sólo en la capital limeña.

TN: ¿Cómo surge la idea de realizar un Cine Club en provincia?

Milton Galopiña (MG): Surgió de los alumnos de la cuarta promoción de la Universidad Católica Santo Toribio de Mogrovejo. Ellos se dieron cuenta cuando llevaron el taller de Apreciación Cinematográfica que un curso de un semestre era muy poco para tener un conocimiento básico de cine, y en coordinación conmigo, como profesor del taller, nos agenciamos de películas, pedimos salón, equipo y listo, empezamos a funcionar.

TN: ¿Quién escoge las películas que se proyectan en el Cine Club? 
MG: En principio las elegíamos con el grupo que inició, pero ellos ya egresaron, así que tomamos en cuenta las sugerencias que nos hacen llegar por Facebook y conversamos con los otros profesores de audiovisuales.

TN: ¿Cuáles son las expectativas que presentan los asistentes al Cine Club?

MG: Conocer más del cine que ellos saben que no pueden acceder, como cine clásico de Hollywood, cine oriental, europeo, géneros como el anime, directores tan diversos como Frank Capra, Kitano o Leone. Aunque a veces ese cine pueden verlo en el cable o en internet, saben que no es lo mismo verlo en pantalla gigante y sonido dolby. Claro, también están los que se hacen falsas expectativas y piensan encontrar aquí lo que se perdieron en el Cineplanet, y al final terminan quedándose con nuestra oferta, aunque de cuando en cuando les ofrecemos un ciclo más acorde con sus gustos.

TN: ¿Cómo procesan los asistentes y/o estudiantes lo que le dicen en el Cine Club?

MG: Somos breves en la introducción. Hablamos sobre las circunstancias del filme, de su director, de sus protagonistas, e indicamos donde pueden encontrar más información sobre ellos. Generalmente se les queda en la mente, y así van descubriendo cosas.

TN: ¿Cuál es el tipo de espectador que asiste al Cine Club?

MG: En su mayoría estudiantes. La mayoría de los del curso, ellos a su vez desarrollan su cinefilia, y luego de que llevan el curso, se convierten en cinéfilos. De cuando en cuando va algún profesor y en menor cantidad algún padre de familia.

TN: ¿Cuáles son las preferencias de los asistentes al Cine Club? ¿Algún tipo de cine en particular? 
MG: Los ciclos más exitosos hasta al momento han sido los de "terror actual", que se repite todos los años desde el 2008 (si sigue así va camino a convertirse en una muestra), el musical (dos ciclos, uno clásico y uno moderno) y el anime que también va por los dos ciclos.

TN: ¿Las vocaciones de los asistentes influyen en la programación?

MG: No mucho. La mayoría de los asistentes son de comunicación, alguna vez sugirieron un ciclo de periodismo, el cual por cierto no fue muy exitoso y ese creo que fue el único caso. Los profesores de otras carreras a veces nos piden que les sugiramos ciclos o películas, pero para pasarlas en sus clases.

Finalmente, Milton Galopiña opina fuertemente sobre la realización de un cineclub alternativo a la propuesta de las carteleras que se ofrecen. Deja en claro:

"La cartelera local es cada vez más mediocre, con blockbusters que se quedan meses de meses, sin dejar lugar a películas independientes, o extranjeras. Imagínense si la cartelera ya es mediocre en Lima con varias salas de pantallas múltiples, imagínense lo que será acá en Chiclayo, donde solo contamos con un solo multicine, por muchas salas que tenga. Además, para formar a los chicos, no se puede recurrir al cine actual, por eso siempre tratamos de incluir cine clásico en nuestros ciclos". 


\section{Entrevista a Osvaldo Burgos - Venezuela}

Osvaldo Burgos García es profesor de Comunicación Social en la Universidad Católica Andrés Bello de Venezuela, luego de su ponencia en la mesa 1.1 "Escenarios de las industrias audiovisuales" - FELAFACS 2012, respondió con mucha gentileza dos preguntas que refuerzan la idea del proyecto, dejando de lado, nociones utópicas acerca del mismo, es más, asegura la sostenibilidad del proyecto.

TN: ¿Qué opina de la creación de un proyecto como Cine Debate en un escenario actual?

Osvaldo Burgos (OB): Cuando yo estudiaba en la universidad, crecí asistiendo a cineclubs y cine debates de la misma casa de estudios y me gustaba mucho la experiencia que ahí surgía, ya que no solo aprendíamos a ver otros cines, sino que también participábamos con nuestros granitos de arena en relación a comentarios sobra tal o cual film y de ahí que salimos con ganas de escribir una crítica, una apreciación o hacer una película. Creo que sirvió mucho en mi formación poder debatir acerca de cine con otros colegas.

Lo que tú propones es muy provechoso, ya que va a existir debate de todas maneras. Colega, usted sabe, ya sea por ideologías, pareceres, estilos de vida, entre otros factores que son yuxtapuestos en muchos casos como estoy seguro que lo demostrará tu público asistente al ver los filmes.

Pero, creo que deberías de apostar por una plataforma virtual que sea como una ventana en donde cuelgues estos trabajos independientes a miles de estudiantes y aficionados. 
No por ello, estoy diciendo que dejes de lado este proyecto, por el contrario, realízalo, haz que todos vengan a ver algo realmente novedoso que propones y no te olvides, creo que lo tienes claro, de la participación de los asistentes y a la vez crea experiencias entre los asistentes y los trabajos audiovisuales.

Créeme los nuevos espectadores y los nuevos cineastas deben de entender que se busca ahora y se le da suma importancia al valor agregado de sus propuestas, que generalmente se encuentra en la experiencia que ofrecen las mismas a un público espectador.

Finalmente, busca un público que apoye esto y refuerza tu cordón umbilical con ellos desde el primer encuentro, recuerda que queda mucho de la "experiencia" a la hora de asistir a un evento y más aún, aprovecha las asociaciones, es por ello que yo creo que la experiencia cinematográfica será siempre irremplazable. Tu meta está en que ahora frente a los nuevos consumos que realizan los cineastas, estudiantes de comunicación, aficionados y profesores debatan en un mismo espacio, tiempo y lugar a pesar de estar en la modernidad líquida.

$\mathrm{TN}:$ ¿Cree que este proyecto sería sostenible en una plataforma virtual?

OB: Sí, por dos razones. Yo sé que me hablas de la brecha digital que existe actualmente en Perú y que muchos chicos de las universidades nacionales pagan por acceso a internet y que encima muchos de ellos no cuentan con una computadora y ni que hablar del acceso invisible que padecen en relación a la conectividad inalámbrica al servicio wifi de internet.

Pero fíjate en una cuestión, hace más de 10 años era casi imposible predecir que las personas tuvieran computadoras portátiles y míranos ahora, la brecha digital latinoamericana ha disminuido, no obstante, creo que en tu caso funcionaría porque ya tienes un nicho corpóreo, un 
público seguidor del proyecto, utiliza esta ventaja y haz de este proyecto un proyecto interactivo, emplea todas las ventajas que ofrece esta onda a la que se está irrevocablemente inmersos la transmedia y más aún, en un asunto que busca fomentar el debate no solo con un público de universidades limeñas sino más adelante latinoamericanas, en donde se difundan todos los trabajos posibles de cortos y largos de estudiantes y egresados.

\section{Entrevista a Sofía Velásquez - Cine Tertulia}

La documentalista Sofía Velásquez fue entrevistada y a la vez, invitada del evento piloto Cine Debate. Realizarle una entrevista fue enriquecedor para el proyecto, ya que, Velásquez tiene un proyecto basado en referentes de cineclubs con el nombre de "Cine Tertulia".

\section{TN: ¿En qué consiste "Cine Tertulia”?}

Sofía Velásquez (SV): Este proyecto busca tocar diversos temas y disciplinas proyectados en un filme y comentados por especialistas de dichos temas y disciplinas, y luego interactuar con el público a través del debate, preguntas o comentarios que lleguen a surgir.

Queríamos tener la perspectiva de varios tipos de invitados, hemos tenido desde poetas, críticos de cine, poetas, escritores, filósofos, músicos, guionistas. En otras palabras, se trata de discutir el cine a partir de muchas perspectivas. 


\section{TN: ¿Cómo estaba organizado el proyecto “Cine Tertulia”?}

SV: Bueno, en la cabeza del mismo estábamos mi amiga y yo, nos encargamos de todo, desde buscar a los invitados, la selección de los filmes en función a un tema, disciplina, arte, etc. y de convocar al experto en esa área, hasta buscar lo que íbamos a preparar de comer.

Sabes, precisamente Tertulia se debe a que preparamos aperitivos y creábamos un ambiente de tertulia entre todos.

TN: ¿“Cine Tertulia” es financiado por ustedes dos?

SV: En un principio, pero luego no. Ya que cobramos ocho soles la entrada, de ahí sacamos para pagar el alquiler del espacio y los insumos para poder hacer la comida o cualquier otro requerimiento. Además, con el tiempo incorporamos un pequeño porcentaje de otros ingresos, por ejemplo, de la productora "Mercado Central".

Aunque tengo que confesar que cada vez es más difícil mantenerlo en pie, porque a veces no tenemos tiempo de conseguir a los invitados, cada una está haciendo mil cosas o salen otras, en varias oportunidades nosotras hemos tenido que comentar o presentar la película, pero siempre tenemos o contamos con un público muy participativo.

"Cine Tertulia" se disfruta los últimos domingos de cada mes en el Instituto de Psicoterapia Psicoanalítica José Gálvez, cuentan con una página en Facebook para más información sobre las proyecciones y los invitados. 


\subsection{Respuestas a encuestas con preguntas abiertas (método cuantitativo)}

\section{$\underline{\text { Universidad de Lima }-2014}$}

Entrevistas a estudiantes con la siguiente pregunta: “¿Qué les gustaría ver en un evento de cine peruano como Cine Debate que busca la promoción y exhibición del mismo?”

\section{Alessandra Castagnola (estudiante de Comunicaciones X ciclo)}

"Me gustaría ver películas en donde pueda apreciar la descomposición narrativa y del tiempo en muchos filmes. A la vez, hacer crítica y análisis en la técnica, el sonido en relación a los efectos, la música que es la armonía, hay películas que te cuentan una historia de un pasado cultural común que tenemos y de ahí se puede sacar un análisis muy rico a través del debate.”

\section{Anais Quispe (estudiante de Comunicaciones X ciclo)}

"Para mí la película peruana en relación a la propuesta artística no es buena, ya que siento un vacío en la dirección que se le da a la propuesta artística, a diferencia del cine alemán en donde hay una dirección permanente. Por otro lado, siento que no hay espacios emocionales en muchas de las películas peruanas que si bien es cierto puede ser un quiebre del guión, no lo es todo. Me gustaría ver un nuevo cine peruano que apuesta por otras vanguardias y deja de lado lo comercial." 
Diana Montedoro (estudiante de Comunicaciones IX ciclo)

"Me parece interesante ver cine peruano, ya que no siento que está muy explotado, siento que, en la misma facultad, en el único curso de Cine Peruano y Latinoamericano, más pasan películas de México, Brasil y Argentina que nacional. Considero que es importante conocer más de lo que se hace acá, sumado a otras opiniones que se darán en el debate, eso te da otra perspectiva para aterrizar como realizadores peruanos y ver que se puede cambiar o mejorar."

\section{Franco Guiulfo (estudiante de Comunicaciones IX ciclo)}

"Me gustaría ver más cine peruano independiente, ya que la mayoría de sus propuestas están llenas de creatividad y minimalismo $y$, en consecuencia, nos nutre mucho como comunicadores y poco a poco se va formando una cultura audiovisual más integradora, con la finalidad de debatir en base a sus propuestas y temas, y no tanto ver las películas que se encuentran más a nuestro alcance.”

\section{Frank Sánchez (estudiante de VIII ciclo)}

"Me gustaría ver cine italiano con sus máximos representantes como Fellini, Darío Arguento, pero también cine peruano, sobre todo de los años 80 como los filmes que realizó Tamayo, Chicho Durán. No obstante, también quisiera ver otro tipo de películas peruanas que no se exhiben mucho para poder debatir sobre ellas y aprender más sobre cómo se está apostando por la realización de las mismas." 
Gonzalo Ruiz (estudiante de VIII ciclo)

"Me siento influenciado por el cine de los 90 hollywoodense, ya que he crecido con el mismo, no obstante, no me gustan las readaptaciones de las mismas, prefiero ver las originales, además, me gustaría ver más sobre el género del terror clase B, que no se visualiza fácilmente, también los filmes románticos cincuenteros, en general me gusta el cine y quiero ver filmes nuevos y aprender más sobre la realización a través de la comparación con todo lo previo que he visto."

Nicolás Cavassa (estudiante de VIII ciclo)

"Sí vería películas peruanas con la finalidad de darle un enfoque más profundo al cine peruano, explotar más el trato en el guión, que considero que no es tan creativo y siempre está rodeado de clichés. Otro punto es rescatar la diversidad de temas que se pueden explorar y llevarlos a su máxima expresión.”

Víctor Cerpa (estudiante de X ciclo)

"Pienso que primero se debe buscar generar una cultura de cine y no ver tantas películas caletas o minimalistas, primero hay que empezar viendo películas que no sean comerciales, pero si accesibles para todos los presentes en términos de lenguaje y narrativa audiovisual, y de ahí ya ir poco a poco fraccionando estilos y corrientes, y de ahí armar un programa cada semana de acuerdo a ello.” 
Jorge Ossio (estudiante de X ciclo)

"Propongo ver más cine independiente tanto nacional como internacional con la finalidad de hacer mejores conjeturas, diferencias, apreciaciones, comparaciones y apostar por lo menos comercializado."

Jorge Aguayo (estudiante de VIII ciclo)

"Deseo ver más cine caleta, marginal, independiente, en donde el realizador controle todo a través de su tesis, crítica o epifanía. Es más, yo creo que el cine habla por sí mismo.”

Karin Palomino (estudiante de X ciclo)

"Me gustaría ver más cine peruano, pero no el centralizado, sino el que muestra más de la temática regional y cultural del interior del país.”

José Miguel Vizcarra (estudiante de IX ciclo)

"Me gustaría ver más documentales peruanos contemporáneos como los que hace el loco Pérez u otros jóvenes que apuestan por el documental de tipo performance y siempre aplican un ángulo diferencial a sus propuestas y eso es lo que lo hace único. Considero que no existen espacios de proyección de estos trabajos cuando se supone que se quiere crear una cultura cinematográfica nacional, pero sin embargo no se apoya a los implicados.” 
André Moyo (estudiante de VIII ciclo)

"Quiero ver más películas peruanas porque me interesa mucho el apoyo que se les está dando a jóvenes actores como yo, quiero ver bien el tema de los guiones, que películas me convienen o no, si el cine independiente podrá librarse de la etiqueta negra que tiene el cine nacional comercial."

Yohei Icochea (estudiante de IX ciclo)

"Existe muy poco apoyo a los jóvenes realizadores regionales que hacen cine, me gustaría ver más realizaciones suyas, ya que muchas de sus propuestas suelen ganar premios en festivales internacionales y nosotros ni enterados de estos logros, por otro lado, entre todos seguir creando más plataformas para la difusión de este tipo de cine nacional que se encuentra en la periferia y sin apoyo por parte de un Estado invisible."

\section{$\underline{\text { Universidad Nacional Mayor de San Marcos (UNMSM) - } 2014}$}

Las entrevistas se realizaron en la facultad de Letras y Comunicación, cuyos estudiantes están organizados por grupos, que les llaman bases. Se pudo apreciar y observar a un grupo de chicos ciegos que estudian Comunicación y aman ver cine y es realmente enriquecedor descubrir que existen programas y nuevas tecnologías que permiten la autorrealización de estos jóvenes, cuya 
sensibilidad es abrumadora a la hora de hablar de una pieza del séptimo arte. La pregunta que también se les realizó fue: “Qué quieren ver en este espacio?”. A continuación, un collage de respuestas por parte de estos jóvenes.

\section{Julio Fernández (Base 8)}

"Me gustaría ver películas peruanas de corte regional, para fomentar más nuestra cultura como lo hacen en otros países como Estados Unidos, ya que conocemos más de la cultura americana que de la nuestra, porque el poder mediático que tienen es impresionante. Sugiero que si se creará un cine regional peruano se podría lograr generar una identidad peruana colectiva, se podría conocer más sobre nuestra cultura y a la vez tendríamos miles de historias que contar a través del lenguaje cinematográfico, que se logre difundir nuestra cultura a través del cine, para ello hay que ver y conocer más sobre nuestro cine para poder compararlo, y claro está, aprender del cine internacional.”

\section{Eduardo Salas (Base 8)}

"Me gustaría ver películas nacionales, pero también extranjeras para poder comparar estilos y visiones de los realizadores acerca del trato del tema, la historia y la puesta final. Eso sí, resalto qué es importante situarse bien en el tiempo y en el espacio socio-cultural para poder entender mejor, si se proyecta un filme de los años 80 en Francia, que también se proyecte un filme peruano de los años 80 , en ese sentido aprendemos cómo el cine muestra un punto de 
vista (realizador) para tratar un tema o una historia situada en un determinado tiempo y espacio."

\section{Carmen Arauco (Base 7)}

"Me gustaría ver películas peruanas y latinoamericanas porque considero que todas tienen un pasado histórico común y es rico ver este tipo de historias, relatos, autobiografías, a través de una cinta cinematográfica ya sea un corto o largometraje y debatir sobre su evolución y lo que se puede lograr ahora, sobre todo en la actualidad ya que se goza de la expresión "El Perú está de moda" y la importancia que se le está dando a la marca "Perú", se debe explotar al máximo la realización de documentales o cortos que expongan nuestra cultura y seguir aprendiendo más en círculos vivenciales con personas que queremos hacer cine para aprender más y ver más.”

\section{Daniel Gallegos (Base 9)}

"Me gustaría ver más cine de otros lados, de otras industrias, pero a la vez deseo ver más cine peruano, eso sí que sea una fusión entre lo que hubo antes con lo que vemos ahora. No obstante, me gustaría ver otras propuestas en el trato de temas sociales que se desarrollan en los filmes tanto extranjeros como nacionales." 


\section{Boris Céspedes (Base 7)}

“Desearía ver más cine francés de los últimos 50 años para aprender más sobre el lado de este cine como un medio artístico y cultural, ya que envuelven muchos de sus films resaltando la cultura francesa. Conozco todo Miami y Nueva York por las películas americanas que he visto y me gustaría hacer algo parecido en el caso del cine peruano, que conozcan más del Perú, no solo Cusco o Lima, sino más sobre otros lugares que se desconocen en el extranjero como la Amazonía, el desierto o los pueblos de las quebradas peruanas, escenarios naturales que otros países explotan y nosotros no.”

\section{Raúl Jiménez (Base 8)}

"Apuesto por ver cine de autor como Scorsese, por ejemplo, ya que ellos tienen una visión particular del trato y la composición en todo sentido de una película. Me gustaría participar en proyectos como el de Cine Debate y sugiero que existiendo tanta versatilidad de gustos se fragmente los gustos por semanas, porque al final esos gustos se pueden mezclar.”

\section{Jhoseth Norabuena Fernández (Base 9)}

"Soy invidente, no obstante, hago constantemente crítica de diversos filmes con temáticas sociales sumado a un análisis filosófico, puesto que estudio Filosofía en la escuela de Letras y Comunicación de la UNMSM. Además, soy el asistente del profesor Atilio Bonilla en el Cine Club Letras de la UNMSM."

- ¿Cómo lo hace? 
"A través de un programa que se llama "YAWNS" el cuál se usa mediante un dispositivo tecnológico que se conecta a la PC, LAP TOP, TV, en donde se describe las imágenes según color, forma, contexto, etc. Sumado a la experiencia auditiva que tengo del filme puedo lograr una retención y comprensión igual que la de un espectador no invidente.”

- Relación con el proyecto Cine Debate

"Sí asistiría porque me interesa mucho escuchar y apreciar más sobre cine nacional para poder comparar otras realidades, pareceres, modos y estilos de vida, psique y puntos de vistas de otros realizadores, y saber bajo que temática se basan para escribir y manipular la herramienta audiovisual."

\section{Vladimir (Base 8 - presidente del PRODE)}

"Deseo ver más sobre cine latinoamericano con temáticas sociales de los que no tienen voz ni voto ni nadie quiere filmar o retratar como son las minorías, por citar un ejemplo, sobre grupos de homosexuales marginados y etiquetados en países como Venezuela, Bolivia y regiones de la sierra en los Andes. Sí asistiría a ver ese tipo de películas, cuyo guión esté plagado por estos temas y debatir sobre el por qué no se apuesta por un cine independiente con énfasis en los revolucionarios de los movimientos marginados, en las sociedades latinoamericanas y cómo estas minorías se han mezclado en nuestro espacio social.” 


\section{Juan Bernal (vendedor de películas y alumno de Literatura)}

"Me gustaría ver películas nacionales, pero de corte alternativo, algo del tipo independiente regional, otras propuestas que no son apoyadas y ni siquiera pueden ser exhibidas tan fácilmente. Ni siquiera hay una cultura que apoye la compra de filmes nacionales, en mi caso yo no vendo nada de cine nacional, vendo cine latinoamericano y europeo, pero a la hora de hablar de cine nacional la demanda prácticamente es nula, esto se debe a que los últimos filmes que se han proyectado en las salas son superficiales y los que deberían de estar en las salas solo se pueden apreciar en festivales o en el extranjero."

\section{Entrevistas en la Pontificia Universidad Católica del Perú (PUCP) - 2014}

Cabe resaltar que fue imposible ingresar a la universidad sin la guía o acompañamiento de un estudiante. Así es que, se opta por preguntar a través de las redes sociales. Los jóvenes que estudian Comunicación no son el único público del proyecto, ya que existen estudiantes de otras carreras que les gusta hacer o ver cine. La pregunta que también se llevó a cabo fue: “¿Qué quieren ver en este espacio?". A continuación, un collage de respuestas por parte de estos jóvenes.

Kelly Rupire (8 ciclo - Ingeniería Civil - Le encanta el cine)

"Me encantan los documentales que cuenten y retraten lugares, y que mejor que ver más de este tipo de documentales, en donde no solo se cuenten historias, sino que a la vez se conozca 
más sobre nuestra geografía nacional. Tengamos saciada nuestra epistefilia de ver algo propio, pero a la vez nuevo. Entonces esto es lo que me gustaría ver, hablar y departir en Cine Debate."

Roberto Chupinagua (6 ciclo - Ciencias de la Comunicación)

"Más cine latinoamericano y darle importancia al tema de la fotografía, la cuál es básica a la hora de encrudecer o enaltecer una realidad. Quisiera ver todo lo que no se exhibe o no es tan accesible de ver, ya que solo estamos expuestos a un tipo de oferta que deja muchas realizaciones fantásticas de lado.”

César Terrazas (9 ciclo - Ingeniería Industrial - Le gusta el cine)

"Quisiera ver un corto nacional y uno extranjero, un documental nacional y uno extranjero, un filme nacional y otro extranjero, definitivamente creo que para que se genere el debate sí o sí tiene que hacerse comparaciones, de las cuales surgen las diferencias o quizás las semejanzas y todos podemos aportar en el aprendizaje conjunto sobre cine. Yo creo que aprender más de cine, es aprender a ver cine, a comparar cine y a saber escuchar y hablar de cine.”

\section{Carmen Armas (8 ciclo - Ciencias de la Comunicación)}

"Creo que se debería de proyectar y ver más sobre nuestro propio cine, ya sea regional, independiente, de autor y agrupar todo para poder hablar por fin de una industria y empezar 
apoyándola nosotros. Conocemos las herramientas de difusión a través de las redes sociales y la web, pero carecemos del apoyo institucional del Estado para la reproducción y auspicio de estas realizaciones que solo se quedan en el baúl de festivales o de proyectos como este. Espero que más bien se use este tipo de proyectos para llamar la atención y poder crear espacios y una cultura de apoyo hacia las realizaciones audiovisuales nacionales que no siempre tienen fines comerciales, como muchas que apreciamos en las salas de cine y ponen en riesgo lo que otros directores y realizadores tratan de construir en el cine nacional.”

\section{Ingrid Montalvo (7 ciclo - Ciencias de la Comunicación)}

"Quisiera ver más cine europeo contemporáneo, ya que se le da suma importancia a la foto retrato en ciertos documentales como los performativos de Couvette. A mí me gusta mucho la fotografía y me da mucha pena que acá no se hagan realizaciones que apoyen este tipo de enfoque de lenguaje y narrativa audiovisual, no siento que el cine nacional avance por sí solo, siempre está limitado por las productoras extranjeras o por las casas distribuidoras y lo que es peor por las ventas y la taquilla."

\section{Mijaíl Castro (6 ciclo - Ingeniería Industrial)}

"Quiero ver más cine peruano, pero que no solo sea de egresados, sino también de chicos de pregrado que casi siempre ganan en festivales nacionales y apoyar más este tipo de cine que surge y que lamentablemente, pasa desapercibido para muchas autoridades nacionales, el 
proyecto de Cine Debate debe reforzar y fomentar visionados de este tipo y discutir siempre soluciones de difusión y exhibición de estos filmes.”

\section{Entrevistas en la Universidad Nacional Federico Villareal (UNFV) - 2014}

Las respuestas fueron muy concisas, ya que, todos los encuestados coincidieron en ver documentales sociales y filmes nacionales independientes, dejando de lado, la temática comercial y hollywoodense. De la misma manera, se realizó la pregunta: “¿Qué quieren ver en este espacio?". A continuación, un collage de respuestas por parte de estos jóvenes y administrativos quiénes tuvieron la amabilidad de participar en el presente estudio de campo brindando su cargo e identificación.

\section{Ingrid Osorio (Coordinadora de Sistemas - presidenta de la Asociación de Montañistas 4.0)}

"Opino que se debe aprovechar este proyecto para poder ver más de todas las nuevas formas, estilos y manifestaciones del cine nacional. Se sabe muy poco del cine de montaña que se quiere hacer o del cine pop que busca la ausencia de la palabra y solo deja que el guión se desarrolle por medio de la fotografía, sonido y un sobrecargado lenguaje audiovisual. Por estas razones, sumado al nulo apoyo del Estado, es mejor apostar por fomentar y difundir nuestro propio cine para poder contribuir con él y a la vez recomiendo que sigas invitando a personas que buscamos invertir en jóvenes realizadores.” 
Carmen Flores (estudiante de Periodismo - 7 ciclo)

"Espero ver más filmes latinoamericanos y nacionales con un guion cada vez más protestante hacia los contextos sociales y políticos que se viven, los cineastas ya no se callan y sitúan sus historias, con la influencia positiva o negativa que repercute en ellos de estos conflictos y el cine es un medio ideal para aprender más sobre ello y hablar sobre lo que ocurre en Latinoamérica y en nuestro territorio nacional."

Anderson Bullón (estudiante de Periodismo - 8 ciclo)

"Creo que, si buscamos crear un espacio para debatir sobre cine, me parece que lo más adecuado de proyectar es nuestros propios filmes, empezar por casa y luego comparar estas propuestas alternativas con otros cines con el objetivo de crear hilos de aprendizaje entre nuestro cine y el cine internacional, pero eso sí, no comercial o el típico cine hollywoodense y su happy ending. Existe creatividad, nuevas propuestas, pero no existe apoyo.”

\section{Lucía Chávez (estudiante de Psicología - 7 ciclo)}

"Definitivamente me gusta el cine, no estudio cine ahora porque empecé estudiando otra carrera que también me gusta y lo que hago es apoyar en la producción de cortometrajes de la Escuela de Cine de Lima y me doy cuenta que el apoyo es escaso por parte del Estado, todo corre por cuenta de los alumnos, y si vamos a generar debate a través del cine, creo que lo mejor es ver lo que se está haciendo en casa y apoyar nuestro cine que pasa desapercibido por 
casas productoras en la actualidad, ya que estas buscan historias que vendan y se ajusten a los requerimientos de festivales."

Jimena Santos, Fiorella Flores y Juan Plasencia (elenco de bailarines de danza contemporánea y estudiantes de Periodismo)

"Nos gustaría ver más de cine alternativo contemporáneo, cero o nula presencia de la industria hollywoodense, creemos que todo lo relacionado al arte no tiene apoyo, ya que lo asocian con lo comercial. Si uno hace arte es considerado desde la familia como alguien que se va a morir de hambre, el Estado no apoya y peor aún si se habla de un cine que quiere mezclar corrientes artísticas con el lenguaje del cine, lo sepultan inmediatamente. Entonces, lo que se ha venido formando es una inversión extranjera o privada hacia estas manifestaciones y que están dando resultado, pero en el extranjero lamentablemente, y aquí nadie sabe nada, no hay una cultura y mucho menos un apoyo. Ahora nos gustaría debatir sobre estos problemas que padece nuestro cine nacional, pero viendo filmes nacionales.”

Los demás jóvenes entrevistados de las facultades de Ciencias de la Comunicación y Psicología que pertenecen a la sede de la Avenida Colonial, dejaron en claro que solo verían películas nacionales o latinoamericanas con temáticas artísticas o sociales, a la vez, no verían filmes que pueden adquirir en Polvos Azules o cine comercial, puesto que, solo buscan entretener quedándose en la superficialidad y no generan cuestionamientos artísticos, sociales y políticos. 


\section{Entrevistas en el Instituto Peruano de Administración de Empresas (IPAE) - 2014}

Las entrevistas que se realizaron en el IPAE apoyan las respuestas que se han venido dando en la UNMSM y en la UNFV, estos jóvenes muestran muchas ganas de ver filmes nacionales de corte alternativo y critican fuertemente los filmes nacionales de corte comercial que ocupan un lugar en la cartelera local. Se les preguntó de la misma manera, “¿Qué quieren ver en este espacio?”. A continuación, un collage de respuestas y apreciaciones por parte de estos jóvenes y administrativos quiénes tuvieron la amabilidad de participar en el presente estudio de campo brindando su cargo e identificación.

Josué Salas (estudiante de Marketing, asistente administrativo en una galería de arte)

"Es interesante escuchar que se va a debatir sobre cine y lo que es mejor quienes lo van a hacer somos nosotros los jóvenes y me gusta la idea porque no hay que confundir lo que se ve en cartelera y enfrascarlo como cine nacional y lo que existe en paralelo a este sistema netamente marketero y comercial que emplean las casas distribuidoras. Desearía ver filmes nacionales que son excluidos de este sistema y hablar desde mi punto de vista, el marketing, sobre las estrategias que se pueden utilizar para fomentar y apoyar a todos estos jóvenes realizadores y seguir creciendo como marca Perú. No necesitamos al Estado, podemos apostar por la inversión privada y extranjera, cuando el Estado se dé cuenta, como siempre será demasiado tarde, y pasará lo que pasa siempre que alguien gane un premio internacional, los 
medios y el Estado harán un acoso mediático y regalarán premios, pero no erradicarán el problema de fondo que es crear políticas para la incentivación y realización de proyectos audiovisuales nacionales."

Fernando Medina (Estudiante de Marketing, Diseñador Independiente)

"Sin temor me atrevería a decir que me gustaría ver más cine latinoamericano que peruano, porque han formado un conjunto de películas que cuestionan socialmente, artísticamente y culturalmente, por ejemplo, la última que me gustó mucho fue la película argentina "El estudiante", te sitúa y deja que la historia se empape por todo el contexto político-social que sufren los universitarios argentinos. Lamentablemente, acá en Perú no se fomenta o mejor dicho no se apoya a jóvenes cineastas que quieren hacer este tipo de filmes con fuertes cuestionamientos sociales y ni que hablar del lado artístico, yo como diseñador y procesador, he visto como chicos de audiovisuales hacen sus productos para sí mismos, ya que no tienen espacios de exhibición y distribución, esta situación es crítica. Así que al escuchar de un Cine Debate me gustaría que se apoye a estos jóvenes y se aprecie más de los filmes latinoamericanos."

Renato Segovia (estudiante de Marketing y asistente de compras)

"Me gustaría poder ver, hablar y apreciar un cine suburbano nacional, nada que ver con el cine comercial que a veces es una decepción y muchos piensan que no queremos apoyar al cine nacional, pero pagar dinero por ver a vedettes como actrices, eso me parece un insulto al 
espectador, acepto que no haya una cultura cinematográfica y que exista ignorancia, pero que no nos agarren de tontos tampoco. Sé que hay buen cine nacional independiente, asisto a la noche de los cortos en Barranco y me gusta mucho lo que veo, este tipo de cine es el que me gustaría ver."

\section{María Laura Rojas (estudiante de Negocios Internacionales)}

"Algo que siempre he querido ver es cine regional, vivimos en una sociedad centralista y solo estamos expuestos a ver un cine que puede pagar a las casas distribuidoras o se limita a lo que le impongan las productoras, que como todos sabemos siempre es lucrar, yo ayudé en la producción de "Mañana te cuento" y me acuerdo que uno de los productores quería sí o sí conseguir atención mediática a través de las personas que iban a actuar, así que exigió que las actrices sean personas polémicas o controversiales, tal es así, que contrató a la modelo Angie Jibaja y a una bailarina o vedette Laisy Suárez. Esto no quiero ver, fue una experiencia que marco mi decisión para estudiar comunicaciones. Así que opino que hay más propuestas regionales que deberían de contar con el apoyo de una ventana y a la vez del ausente Estado.”

\section{$\underline{\text { Centro Cultural Peruano Británico - } 2014}$}

Las entrevistas que se realizaron en el Centro Cultural Peruano Británico apoyan las respuestas que se han venido dando en los centros educativos previos, estos jóvenes muestran muchas ganas de ver filmes nacionales de corte alternativo, no critican fuertemente los filmes 
nacionales que ocupan un lugar en la cartelera local, ya que aseguran "que el cine debe ser para todos los gustos”. Se les preguntó de la misma manera: “¿Qué quieren ver en este espacio?”. A continuación, un collage de respuestas y apreciaciones por parte de estos jóvenes que asisten al centro cultural quiénes tuvieron la amabilidad de participar en el presente estudio de campo brindando su identificación.

Jimena Guinea (estudiante del taller de pintura)

"Me interesa muchísimo ver más del cine peruano alternativo, ya que muchas de estas propuestas cinematográficas quedan en el olvido en una laptop, CD o en un canal on-line. Es genial que se cree un espacio con eventos para promocionar y exhibir más de este otro cine, conocerlo y apoyarlo. Yo asistiría y recomendaría sobre el proyecto Cine Debate.”

Manuel Moreno (estudiante de inglés)

"Qué buena propuesta, ya que no conozco nada de este tipo de cine alternativo, regional, independiente o de autor que se hace aquí en nuestro país. No tenemos una cultura tan vasta al referirnos al séptimo arte. Así que yo feliz de ir a ver este otro tipo de cine. Me gustaría recomendar a la vez, que hagan más difusión en todos los centros culturales que puedan para generar más difusión sobre su proyecto.”

Susana Barrantes (asidua visitante del Centro Cultural Peruano Británico) 
"Definitivamente es una gran iniciativa. He visto películas nacionales, pero no de tipo independiente, regional o alternativo. Siempre pensé que ese tipo de cine solo se hacía en Europa. Pero si se está llevando a cabo aquí en Perú. ¿Por qué no se exhibe más de estas películas? Claro que iría y apoyaría a nuestras promesas del cine.”

\section{Thalía Rosales (asistente fiel del Teatro Peruano Británico)}

"Considero que tenemos un gran capital humano en el mundo del arte y más aún en el cine. Creo en nuestros actores son buenos, los jóvenes cada vez se preparan más para destacar dentro de la industria cinematográfica. Aquí en el centro cultural he visto la acogida de talleres o cursos relacionados al cine. Claro que asistiría y también me gustaría contribuir en su difusión."

\section{Luis Carlos Escobar (asiduo visitante del Centro Cultural Peruano Británico)}

"Me parece excelente la iniciativa. Solo puedo ver este tipo de filmes una o dos veces al año en una universidad o un centro cultural. Pero que sea periódicamente y se convierta en un proyecto sostenible y no quede en el tiempo como eventos piloto. Sí iría.”

\section{Goethe Institut - 2014}

Las entrevistas que se realizaron en el Goethe Institut apoyan las respuestas que se han venido dando en las encuestas realizadas. Se percibe ganas de ver filmes nacionales de corte alternativo, 
independiente o de autor, sumado a ello, se puede inferir que al no haber estas propuestas cinematográficas su deseo de ir a verlas es más fuerte. Se les preguntó de la misma manera: “¿Qué quieren ver en este espacio?”. A continuación, un collage de respuestas y apreciaciones por parte de los asistentes al centro cultural, quiénes tuvieron la amabilidad de participar en el presente estudio de campo brindando su identificación.

Laura Meza (asistente frecuente de los eventos culturales del Goethe Institut)

"Me parece una ambiciosa iniciativa optar por la exhibición de películas peruanas de corte alternativo o independiente. Me gustaría recomendar que primero tomen en cuenta que hay que concientizar sobre el otro cine peruano para que la aceptación al proyecto se vuelva periódica o recurrente, ya que tenemos generalmente un público con gustos más comerciales. Por otro lado, si iría a ver este tipo de películas por mi fuerte gusto por el cine y todas sus manifestaciones."

\section{Guillermo Corzo (estudiante del idioma alemán)}

"Qué éxito, ya que los cineclubs o espacios culturales alternativos no apuestan por exhibir este tipo de cine que venimos teniendo hace décadas atrás. Creo que es importante apoyar a los realizadores y cineastas que tenemos e incentivar su arte y que no quede en el olvido, porque estoy seguro que talento hay solo que desconocemos todo lo que se hace por falta de información y exhibición. Yo si iría y apoyaría con la difusión del proyecto.” 
Junior Rivasplata (asistente frecuente a los eventos musicales del Centro Cultural Goethe Institut)

"Definitivamente el proyecto no solo les daría vitrina a los directores sino a la vez a todo su equipo realizador, quiénes también hacen arte como la creación de la música, el arte, el maquillaje, entre otros, y me resultaría muy interesante asistir a un espacio en donde no solo vea el producto final, sino que sus protagonistas cuenten cómo llegaron a tal resultado cinematográfico. Si iría de todas maneras y me gustaría también que presenten una programación para poder compartirla."

Leila Marcelo (estudiante del idioma alemán)

"Es un proyecto nuevo, fresco y estoy segura que generará un proceso de promoción con contenidos sobre la diferencia de este tipo de cine peruano en relación con el que se exhibe en cartelera, ya que muchos estamos desilusionados de estos trabajos cinematográficos. Y si iría a ver las propuestas alternativas que ofrece el proyecto Cine Debate, que no están en cartelera." 


\subsection{Respuestas a encuestas con preguntas abiertas (método cuantitativo)}

\section{Parque Kennedy (Miraflores) - 2014}

Las entrevistas que se realizaron en el parque Kennedy a los transeúntes, quienes expresaron respuestas, comentarios y apreciaciones que se han venido dando en las encuestas realizadas previamente tanto en los centros educativos como culturales. A la vez, se refuerza las ganas de ver filmes nacionales de corte alternativo, independiente o de autor. Se les preguntó: “¿Qué quieren ver en este espacio?’. A continuación, un collage de respuestas y apreciaciones por parte de los entrevistados, quiénes tuvieron la amabilidad de participar en el presente estudio de campo brindando su identificación.

Fernando Dazo (23 años)

"Me parece una súper idea optar por la exhibición de películas peruanas de corte alternativo o independiente. Apoyemos más al cine peruano que al extranjero.”

Stephanie Rosales (24 años)

"Lo máximo. Creo que es importante apoyar a los realizadores y cineastas que tenemos aquí en el Perú e incentivar su arte y que no queden en un baúl de recuerdos no exhibidos, en el país hay talento, lo que falta es apoyo.” 
Jorge Bobadilla (25 años)

"Espero que el proyecto Cine Debate cuente con el apoyo del estado y se empiece a formar una adecuada red de apoyo al otro cine peruano que considero posee mucho talento y queda desplazado por un cine peruano comercial con mala imagen y superficial que se aprecia en las carteleras limeñas”.

Omar Crispín (27 años)

"Si asistiría a Cine Debate, porque me gustaría ver las propuestas cinematográficas que ofrece el otro cine peruano."

\section{Parque El Olivar (San Isidro) - 2014}

Las entrevistas refuerzan las ganas de ver filmes nacionales de corte alternativo, independiente o de autor. Se les preguntó: “¿Qué quieren ver en este espacio?”. A continuación, un collage de respuestas y apreciaciones por parte de los entrevistados, quiénes tuvieron la amabilidad de participar en el presente estudio de campo brindando su identificación. 
Jimena Flores (27 años)

"Es la primera vez que escucho sobre un proyecto que nos muestre sobre otros tipos de cine que se hacen en el Perú. No he visto este otro tipo de cine, pero me gustaría verlo e iría a los visionados de sus proyecciones. Me gustaría recomendar que lleven a cabo campañas de promoción o difusión para que más personas apoyen esta iniciativa.”

\section{Ghiojaira Álvarez (28 años)}

"Conozco círculos de cine, cineclubs y eventos en donde se proyectan este tipo de cine alternativo o independiente, pero de cine nacional son contados con los dedos. Me gustaría asistir y poder apreciar las realizaciones que se hacen con talento nacional y que no cuentan con una vitrina en una cadena comercial.”

\section{Guillermo Hernández (19 años)}

"Es inusual encontrar un proyecto que aborde nuestros productos cinematográficos que se encuentran en segundo plano por parte de las cadenas distribuidoras de películas comerciales como las de Hollywood. Si asistiría porque creo que tenemos talentos ocultos y merecen ser conocidos, así como nuestro apoyo como peruanos. También, ¿por qué no exportar nuestras películas? Quizá lleguemos a tener una industria cinematográfica. 


\section{Bruno Cardozo (20 años)}

"Me encanta el cine alternativo como el cine argentino y el español. Me gusta el cineasta Francisco Lombardi muchísimo y creo que como él hay muchos más en el Perú, ojalá se sigan realizando este tipo de proyectos para poder apreciar más cine hecho en casa. Sí iría y quisiera acotar que el debate permitirá que también los espectadores aporten y se formen grandes ideas o síntesis de todo lo que se está produciendo."

\section{Parque San Pablo II (San Miguel) - 2014}

Las entrevistas refuerzan las ganas de todos los encuestados por ver y conocer sobre el cine peruano autogestionado. Se les preguntó: “¿Qué quieren ver en este espacio?”. A continuación, un collage de respuestas y apreciaciones por parte de los entrevistados, quiénes tuvieron la amabilidad de participar en el presente estudio de campo brindando su identificación.

\section{Romina Ocrospoma (19 años)}

"Estaría súper ver nuevas propuestas de cine que se hace, pero no tenemos acceso a ello, ya que no hay mucha promoción o publicidad, yo quería estudiar la carrera de cine, pero aún no la hay con una malla curricular, y son muy pocas las facultades de comunicación que apoyan o cuentan con círculos de exhibición de dichos filmes nacionales. Yo si iría a ver y me encantaría apoyar por mi fuerte gusto por hacer películas.” 
Trilce Díaz (23 años)

"Iría y a la vez, apoyaría, ya que necesitamos del voluntariado cultural para poder llegar al objetivo de sostenibilidad del proyecto, que imagino debe tener. Yo hago voluntariado con fines culturales para un centro cultural y una organización y me encanta la idea de apoyar y visionar a nuestro cine de corte alternativo que carece de apoyo institucional, de auspiciadores o inversionistas."

Marco Valle (29 años)

“Generalmente, tenemos una idea sobre el cine nacional que no es nada favorable, ya que los temas que aborda son muy machistas, sexuales y plagado de groserías, a mi parecer. Por lo tanto, saber que existe otro tipo de cine con otras propuestas me resulta muy favorable para limpiar muchas percepciones que tenemos sobre el cine nacional. Sí iría.”

\section{Valeria Cubillas (20 años)}

"Claro que asistiría, ya que debemos seguir haciendo del Perú una marca a través de todas sus manifestaciones culturales y en el caso de nuestro cine más aún, porque considero que debe tomarse como escenario todos nuestros espacios geográficos que están llenos de belleza natural. Más del otro cine peruano para todos. Les deseo muchos éxitos.” 


\subsection{Encuestas con preguntas abiertas (método cuantitativo)}

Al momento de llevar a cabo el evento piloto en el año 2013 existían muchas dudas sobre la proyección de realizaciones peruanas, tanto de estudiantes como de cineastas con trayectoria. Así es que, se apostó por realizar encuestas para tomar una decisión sobre la elección de trabajos audiovisuales que se irían a proyectar.

Finalidad de las encuestas:

- Determinar si a los asistentes les gustaría ver trabajos audiovisuales (cortometrajes o largometrajes) a cargo de jóvenes realizadores peruanos.

- Establecer si les agradaría que uno de los realizadores sea un estudiante y el otro un realizador profesional con más experiencia.

\section{Facultad de Comunicación y Letras de la UNMSM}

Muestra:

Quince estudiantes de la facultad de Comunicación y Letras de la UNMSM.

\section{Preguntas:}

1. ¿Les gustaría ver cortometrajes o largometrajes en el Cine Debate de jóvenes realizadores peruanos? 


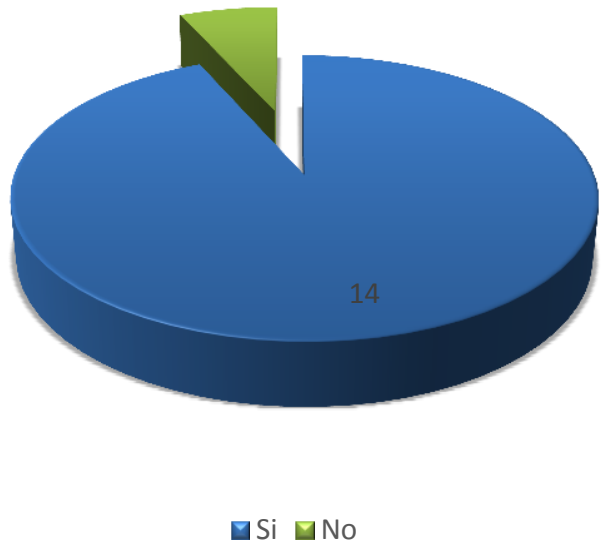

Razones principales:

- La novedad de ver otro tipo de productos nacionales.

- Hacer comparaciones con otros productos nacionales, inferir las diferencias o semejanzas, ver los estilos y tratos de la trama (historia).

2. ¿Te gustaría que uno de los filmes proyectados esté a cargo un estudiante de Comunicación Audiovisual con especialización en Dirección y el otro a cargo de un egresado con más experiencia? 


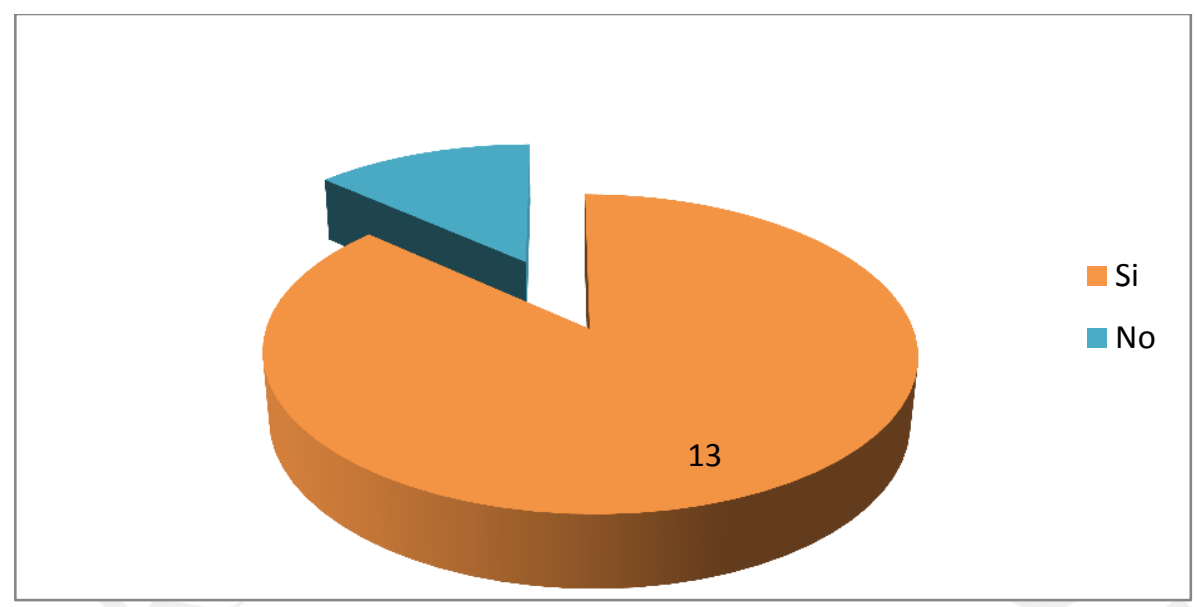

Razones principales:

- Darle la oportunidad al estudiante de poder proyectar su trabajo audiovisual y a la vez, éste podrá recibir críticas en relación a su cortometraje no solo por parte de estudiantes al igual que él, sino también por parte del otro realizador que ya tiene más experiencia en el campo.

Poder comparar ambas propuestas y el estilo a la hora de contar una historia.

\section{Facultad de Comunicación de la Universidad de Lima}

\section{Muestra:}

Treinta estudiantes de las facultades de Comunicación, Derecho y Psicología.

\section{Preguntas:}

1. ¿Les gustaría ver cortometrajes o largometrajes en el Cine Debate de jóvenes realizadores peruanos? 


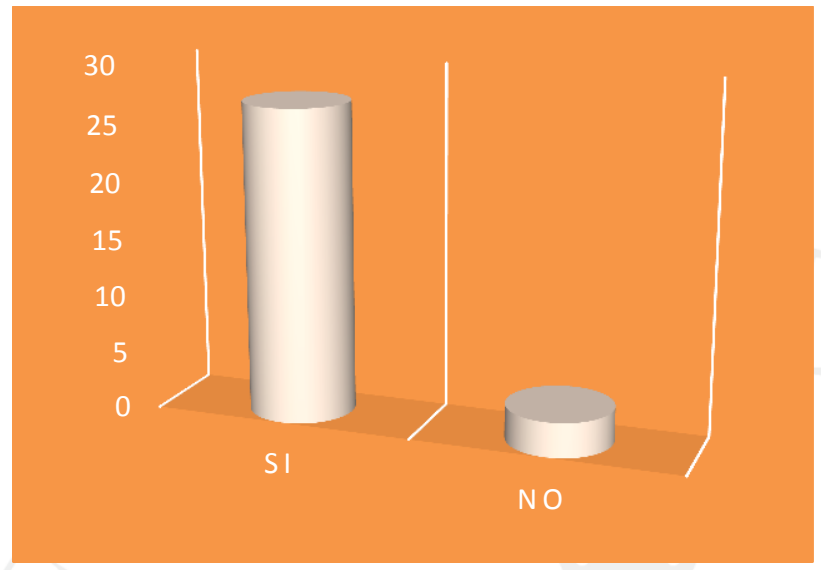

Razones principales:

A los encuestados sí les gustaría ver este tipo de proyectos, ya que apoyan a los jóvenes realizadores que no cuentan con lugares como la Ventana Indiscreta con las instalaciones adecuadas para exhibir sus proyectos audiovisuales.

- Además, les interesaría ver el tratamiento audiovisual tanto del lenguaje como de la narrativa (fotografía, iluminación, cámara, sonido, dirección de arte, guion, entre otros) que presentan los cortometrajes o largometrajes de corte independiente y compararlos con otros.

2. ¿Te gustaría que uno de los cortos proyectados esté a cargo un estudiante de Comunicación Audiovisual con especialización en Dirección y el otro a cargo de un egresado con más experiencia? 


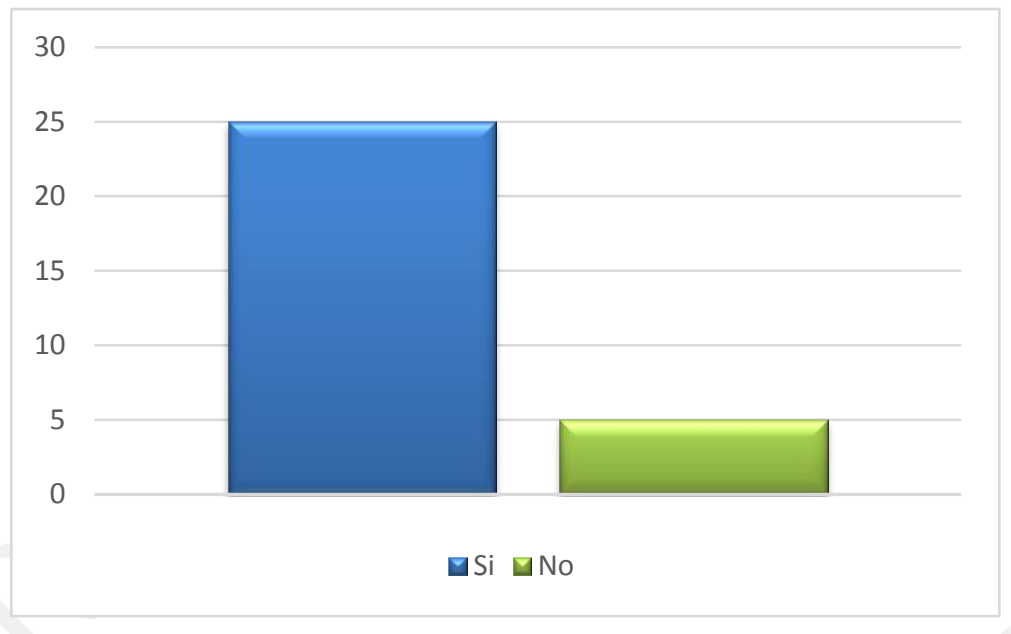

Razones principales:

- Los encuestados manifestaron su gusto por ver el planteamiento de un estudiante y compararlo con el de un egresado que ya se pueden llegar a formar muchos aportes y un conocimiento enriquecedor.

- Les agrada la idea de ver nuevos enfoques, nuevos tratamientos, autenticidad y el estilo que manejan los jóvenes realizadores en la actualidad.

- $\quad$ Por otro lado, les interesa que este espacio funcione como un medio para difundir nuevos productos audiovisuales de estudiantes como de egresados, pero que no tienen tanta exhibición. 


\subsection{Observación natural (método cualitativo)}

\section{$\underline{\text { Semejanzas y diferencias con Cine Club Chiclayo - } 2014}$}

- La principal semejanza radica en el concepto que se tiene por cineclub: Ver y conocer más sobre un tipo de cine no comercial, por citarlo de algún modo. Luego, se busca que todos sean parte de la experiencia cinematográfica que otorgan ambos espacios.

- Otra semejanza que se encuentra es el deseo que surge en ambos proyectos por conocer otro tipo de cine, en el caso del Cine Club de Chiclayo actualmente se encuentran en plena recopilación de cine anime y están discutiendo mucho sobre la narrativa que este presenta; en el caso específico del proyecto de Cine Debate, también existe un deseo de conocimiento al momento de hablar de otras propuestas del cine de autor, independiente y alternativo por parte de jóvenes realizadores peruanos. Y en ambos proyectos la vocación del público asistente no influye a la hora de proyectar un filme, ya que, todos buscan ver otro tipo de cine que se aleje del comercial.

- En el caso de diferencias, tenemos que mientras en el Cine Club Chiclayo los que escogen los filmes son un grupo de profesores y dicho grupo conforman el equipo que está a cargo del cineclub, quienes aceptan sugerencias por parte de su público asistente a través de las redes sociales, destacando Facebook. En el proyecto Cine Debate no es así, la directora es la encargada de buscar a jóvenes realizadores peruanos, que quieran proyectar, difundir y hablar de sus realizaciones con el público asistente. También se reciben sugerencias, pero al final quien decide si proyecta o no lo que le recomiendan es 
la directora; esto se debe a la experiencia que ha adquirido con el tiempo en la selección. Tenemos la siguiente anécdota: "En el trabajo previo de campo la directora conoció a chicos de la Universidad Nacional Mayor de San Marcos que se dedican a realizar documentales como el "Corazón del Conga", estos trabajos audiovisuales tienen en primer plano el punto de vista político en defensa de grupos terroristas como Movimiento Revolucionario Túpac Amaru (MRTA) y Sendero Luminoso (SL), debido a ello, se optó por no proyectarlas en la programación de Cine Debate, principalmente porque el cine en este caso es utilizado con fines propagandísticos y con objetivos claros en el guion de "humanizar" a genocidas.

- Otra diferencia resaltante es que el proyecto Cine Debate no realiza aún actividades que promuevan otros proyectos en relación al cine todavía, como sí lo hace el Cine Club Chiclayo que promueve mediante la autogestión una exitosa revista dedicada al cine. No obstante, el proyecto se basa en la autogestión y es muy posible que no solo lleve a cabo la realización de una revista sino también otras iniciativas para seguir fomentando, difundiendo, exhibiendo y apoyando a los jóvenes realizadores que desean dejar huella en la esfera del cine nacional y llamar la atención del sector privado que desee apoyar sus proyectos, ya que el Estado hace caso omiso a que la base de una industria y de un mercado cinematográfico es la capacitación y fomentación de realizadores. Son inexistentes las becas para estudiar cine en el extranjero y no se entiende que sería algo muy rico y aprovechable, puesto que los jóvenes traerían todo lo aprendido para hacer cine en casa. 
- Finalmente, ambos proyectos se diferencian en que mientras el Cine Club de Chiclayo, luego de la proyección del filme conversa con los profesores encargados, en el proyecto de Cine Debate se puede conversar directamente con los realizadores del filme y se enriquece mucho más el conocimiento sobre lo que implica la preproducción, grabación y posproducción de los filmes a través de las experiencias que nos cuentan sus directores, productores y demás realizadores. No se está manifestando que en el Cine Club Chiclayo no exista un aprendizaje con los profesores y el debate que se da, simplemente que en cuestión de cine nacional alternativo, independiente y de autor; la promoción es más aprovechable en el espacio de intercambio que ofrece Cine Debate, de la mano con la comunicación horizontal que se genera entre los participantes y asistentes a cada evento; lo cual permite que se cree una atmosfera de confianza para debatir, compartir, conversar, intercambiar y apoyar; los asistentes quieren seguir viendo más de estos realizadores manteniendo el contacto con el proyecto y sus protagonistas.

\section{$\underline{\text { Semejanzas y diferencias con Cine Club Galpón - } 2014}$}

- La principal diferencia se encuentra en los conceptos de ambos proyectos. Galpón es un proyecto que busca impulsar la creación de espacios alternativos en relación a todo tipo de proyectos artísticos de corte independiente, no necesariamente cinematográficos, como lo deja en claro una de sus organizadoras Lorena Peña: “Mi proyecto busca exhibir trabajos audiovisuales de realizadores peruanos, tanto de egresados como de estudiantes, en un espacio rodeado de un público variado y con ganas de ver nuevos formatos y manifestaciones en el arte contemporáneo que atraviesa el Perú”. 
- Se considera que si existe semejanza a la hora de hacer prevalecer la experiencia cinematográfica por parte de ambos proyectos y agrupar a todos en un mismo espacio físico.

- Por otro lado, Galpón al ser un proyecto autogestionado, acepta dinero por parte del público asistente sin un límite específico de contribución, en el caso de Cine Debate no se busca cobrar a los asistentes. Las universidades o espacios en donde se presenta el proyecto generan un monto de viáticos, y en algunos casos un contrato, sin duda alguna, ello permite crear la sostenibilidad del proyecto.

- Ambos proyectos están enfocados en tratar de fomentar y exhibir trabajos independientes o de experimentación que no cuentan con apoyo de difusión y lo cual hace que muchas personas no sepan que existe este tipo de trabajos, no todos tienen acceso a Vimeo o sitios web "caletas", en donde estos jóvenes tienen que dejar colgados sus trabajos. Es por eso, que el filtro que ambos proyectos utilizan en la selección de sus filmes, es buscar lo que se encuentra al otro lado de la línea que dividen las salas comerciales de cine, regidas bajo patrones de mercado, se entiende que son un negocio y están en todo su derecho de buscar siempre equilibrio entre las curvas de la oferta y la demanda existente.

- Al igual que Galpón el proyecto de Cine Debate cuenta con un público objetivo general, no necesariamente estudiantes de comunicaciones, ya que no todos los que estudian comunicaciones hacen cine o se quieren dedicar al mismo o les gusta ver filmes. Tanto Galpón como Cine Debate apoyan a artistas que pueden no tener nociones de difusión y exhibición para sus realizaciones audiovisuales. 


\section{$\underline{\text { Semejanzas y diferencias con el Cine Club UNMSM - } 2014}$}

- La primera diferencia que salta a la vista son las instalaciones en donde se lleva a cabo el Cine Club de Letras UNMSM y en donde se llevaría el proyecto de Cine Debate. En el caso del primero solo cuentan con un salón de clases con carpetas y un televisor medianamente grande (entre 45 y 49 pulgadas aproximadamente), a diferencia de las instalaciones que ofrecen las salas cinematográficas o auditorios de universidades, en donde, se realizan los eventos del proyecto Cine Debate, procurando una experiencia audiovisual más gratificante, con los requerimientos técnicos necesarios. No obstante, hay que dejar en claro que sí se aprecian las características de un cineclub, un grupo de personas, en este caso estudiantes reunidos para ver "otro" tipo de cine en un espacio que cuenta con un moderador y gente que tiene criterio para debatir sobre todos los aspectos que consideran relevantes dentro del filme.

- Los objetivos en cuanto a los proyectos en sí mismos también marcan una diferencia, mientras el Cine Club de Letras UNMSM, según su gestor y director Atilio Bonilla, quien lleva en este cargo 50 años, buscan objetivos meramente académicos, sobre todo en cuanto a complementación de clases, ya sea para reforzar un tema social o para explicar un tema del curso de apreciación cinematográfica, Cine Debate, por otro lado, busca exhibir, promocionar, difundir y debatir productos audiovisuales nacionales de corte independiente, alternativo y de autor, los cuales no cuentan con mucho apoyo en estos temas. A la vez, la plataforma virtual aún no es lo suficientemente accesible para la UNMSM y en algunos casos no conocen la comunicación que ofrece la web 2.0. 
- Como semejanza encontramos en ambos proyectos el cineclubismo como medio cultural, educativo y artístico, en donde el filtro bajo estos parámetros juega un rol importante en la selección de las realizaciones audiovisuales.

- En el caso de los asistentes al Cine Club de letras UNMSM son todos estudiantes de esta casa universitaria en la actualidad; en el caso del proyecto Cine Debate en un principio se pensó que todo el público objetivo serían jóvenes universitarios, pero si bien es cierto que el mayor porcentaje corresponde a universitarios de diversas carreras, se aprecia un público muy variado al que los une la afición y gusto por al cine, de donde, podemos destacar otra diferencia entre ambos proyectos.

- Atilio Bonilla siente que las nuevas formas de ver cine han debilitado el cineclubismo, no obstante, considera que la experiencia cinematográfica nunca perderá su esencia y que este tipo de proyectos rigen hasta la actualidad porque existe un auditorio y eso lo demuestra la experiencia del evento piloto. En el caso específico del Cine Club UNMSM, a pesar de no contar con las instalaciones adecuadas los alumnos van a ver y a conversar sobre los filmes proyectados, y podemos decir que se aprecia la semejanza más relevante de lo que implica un cineclub, su esencia expresada en un espacio físico junto a los actores que abordarán dicho espacio.

\section{$\underline{\text { Semejanzas y diferencias con Cine Tertulia }}$}

- Una diferencia resaltante es el desarrollo de ambos proyectos a la hora de ejecutarlos. Cine Tertulia propone tocar diversos temas y disciplinas proyectados en un filme y comentados por especialistas de dichos temas y disciplinas, y luego interactuar 
con el público a través del debate. En el caso del proyecto Cine Debate si bien es cierto que se quiere discutir sobre un mismo filme desde distintos puntos de vista, el centro siempre es el cine ya sea entendido como expresión o producto y todo lo que pueda acarrear, pero no centrarnos en otras áreas. Por ejemplo, si se proyecta un documental performance de un literato y no se abordará solo temas relacionados a la literatura. Cine Debate no pierde la brújula que es hablar en relación al cine y si surgen otros temas se tocarán, pero siempre se regresará al centro temático que es el cine mismo.

- Otra diferencia es que las organizadoras de Cine Tertulia buscan invitar a un experto en relación al tema que toca el filme, por ejemplo, si la película proyectada habla de músicos ciegos, invitan a un músico ciego, mientras que en el proyecto Cine Debate solo se centra en invitar a cineastas peruanos.

- Finalmente, Cine Tertulia al igual que Cine Club Chiclayo, Galpón y Cine Debate en principio vienen a ser proyectos autogestionados, de donde, todo lo que se recibe a manera de ingreso se reinvierte en el mismo proyecto. 


\section{Cine Debate e Indecopi}

Es de suma importancia entender el derecho de autor, el cual protege exclusivamente la forma original y creativa a las obras artísticas, sociales, culturales, audiovisuales, entre otras. Con la finalidad de no copiar o plagiar, incluso usurpar un proyecto como Cine Debate que presenta un contenido creativo y único, el Instituto Nacional de Defensa de la Competencia y de la Protección Intelectual (Indecopi) es el organismo del Estado peruano que nos permite proteger nuestros derechos como creadores y autores, tomando las respectivas medidas correctivas en caso de plagio.

Se realiza un proceso de registro formal con la finalidad de elaborar una estrategia basada en la gestión cultural al registrar el contenido y el nombre del proyecto Cine Debate, con el fin de que no quede de manera inédita, sino que se realice o se ponga en práctica de manera sostenible y rentable. La característica legal e institucional que otorgan organismos del Estado como Indecopi, son muy valoradas e indispensables cuando se desea llevar a cabo proyectos de gestión cultural como Cine Debate, con resultados exitosos, puesto que se ha presentado en distintas universidades de Lima, centros culturales, incluso en festivales internacionales.

Bajo el número de expediente 001937-2014 y partida registral 013000-2014 se otorga a la directora del proyecto, Tatiana Novoa Osorio, nacida en Rusia el 13/06/1991, con el número de documento de identidad: 47531086, los derechos de autor, titular y editor de Cine Debate: Proyecto multiplataforma que busca la promoción, difusión, exhibición y discusión del cine peruano autogestionado. El día 27 de octubre del 2014, con las firmas del Director de Derechos 
de Autor de Indecopi, Fausto Vienrich Enríquez, y la Dirección de Derechos de Autor de Indecopi, representada por Cristina Madrid Villacorta. 


\section{Cine Debate y la gestión cultural}

"El gestor es siempre un mediador, un caminante entre dos mundos: la cultura y la sociedad, un hacedor de puentes, un soñador realista y un pragmático un poco enloquecido, si se me permite la expresión."5 (Banús, 2015).

Bajo esta reflexión y pensamiento, Cine Debate opta por emprender el camino de la gestión cultural, uniendo la cultura del cine peruano autogestionado con la sociedad en la que vivimos, con la cual mantiene una relación directa, pero que no es conocida. Como consecuencia, el proyecto busca exhibir y difundir los trabajos audiovisuales de directores peruanos que no se llegan a proyectar y son reflejo de una cultura cinematográfica vigente, pero excluida.

Sumado a ello, el proyecto también desea transmitir que la cultura debe entenderse como factor de desarrollo social y humano, lo cual hace más inmediata la necesidad de hacer diligencias conducentes para seguir realizando el proyecto Cine Debate.

El Estado debe apostar por mejorar e implementar más políticas culturales para seguir fomentando la creación de proyectos culturales como Cine Debate. Es importante resaltar que un proyecto cultural como Cine Debate plantea como objetivo la participación de la comunidad

\footnotetext{
${ }^{5}$ Conferencia de Gestión Cultural, Centro Cultural de la UDEP, Enrique Banús, 2015.
} 
(público asistente), mediante la cultura (cine peruano autogestionado), para crear una sociedad abierta y creativa. En esencia: cambio y transformación.

El éxito de la gestión cultural en Cine Debate, se debe a tres factores valiosos que la experiencia de tres años le enseñó al proyecto: un grupo humano competente, comprometido, motivado que forma Cine Debate, la parte legal, que genera formalidad e interés de inversión hacia el proyecto y finalmente, la planeación en base a estrategias en comunicación y marketing.

Cabe resaltar que las estrategias que se emplearon para la planeación fueron dirigidas a entidades privadas, afines al proyecto, que, a su vez, buscaban reducir impuestos apoyando, financiando o patrocinando un proyecto de este tipo.

Aquí los mapas conceptuales sobre la organización en base a la gestión cultural que se lleva a cabo en la constitución del proyecto Cine Debate: 
Figura 3: Año 2014-2015

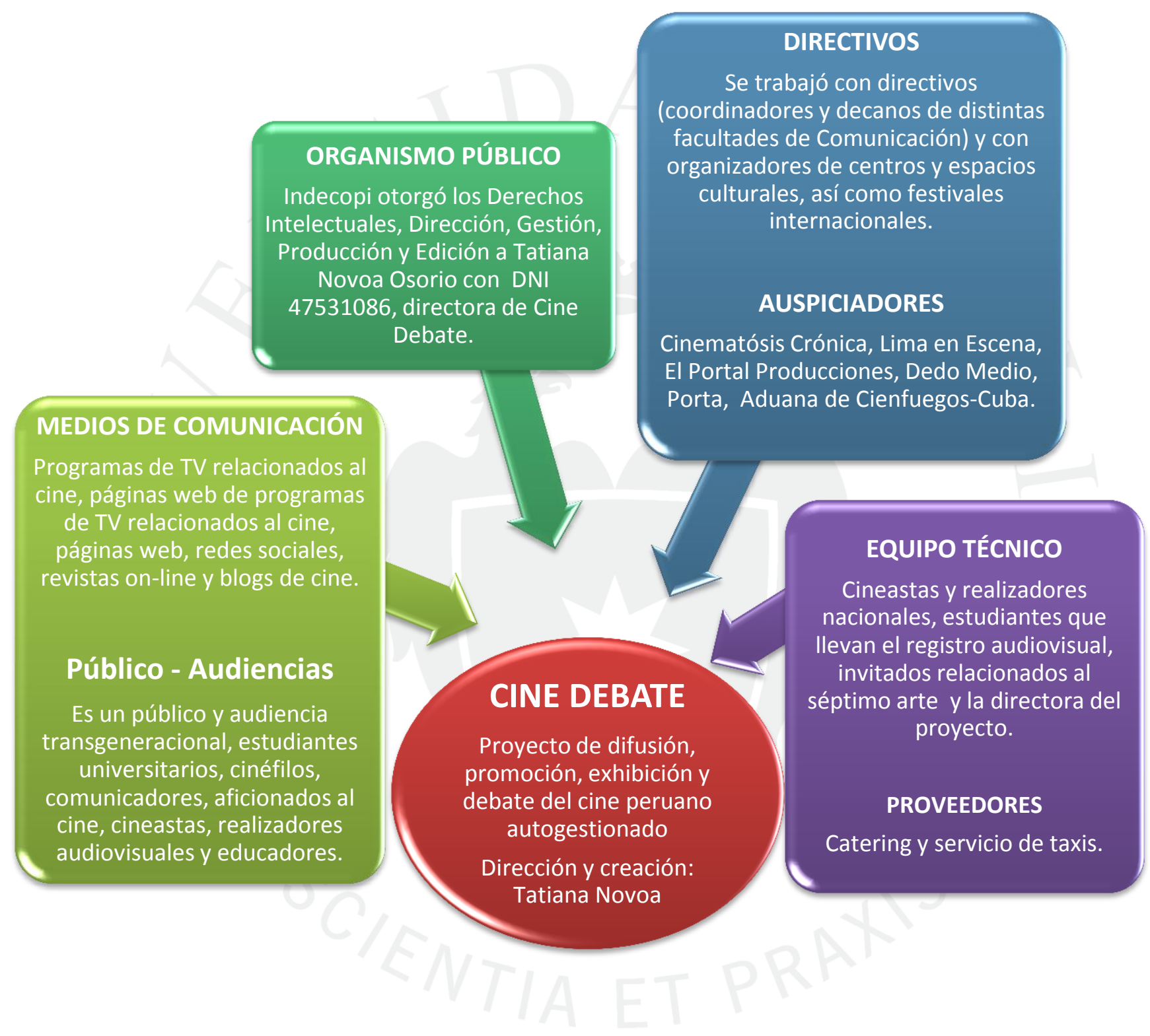


Figura 4: Año 2016

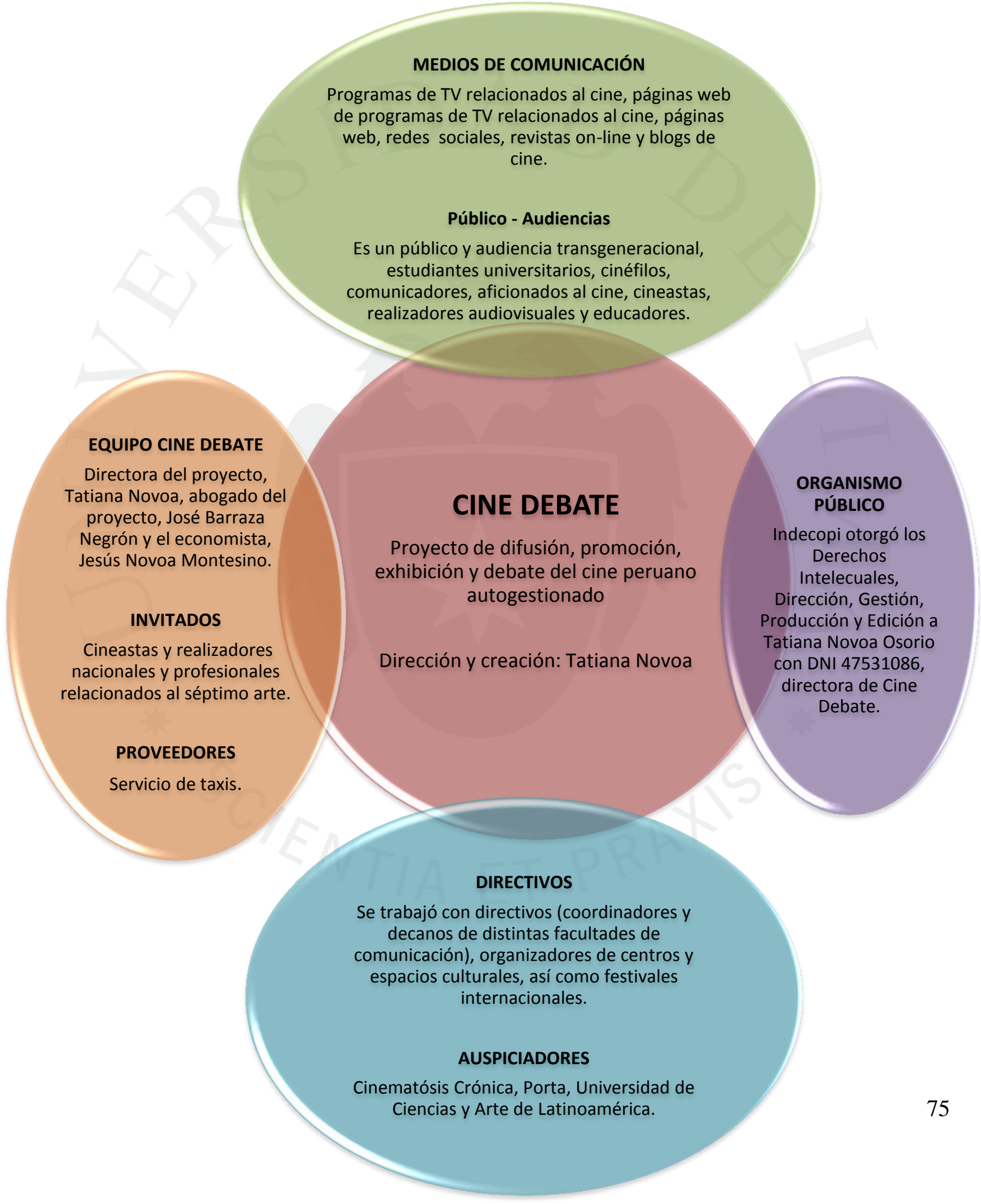


Figura 5: Año 2017-2018

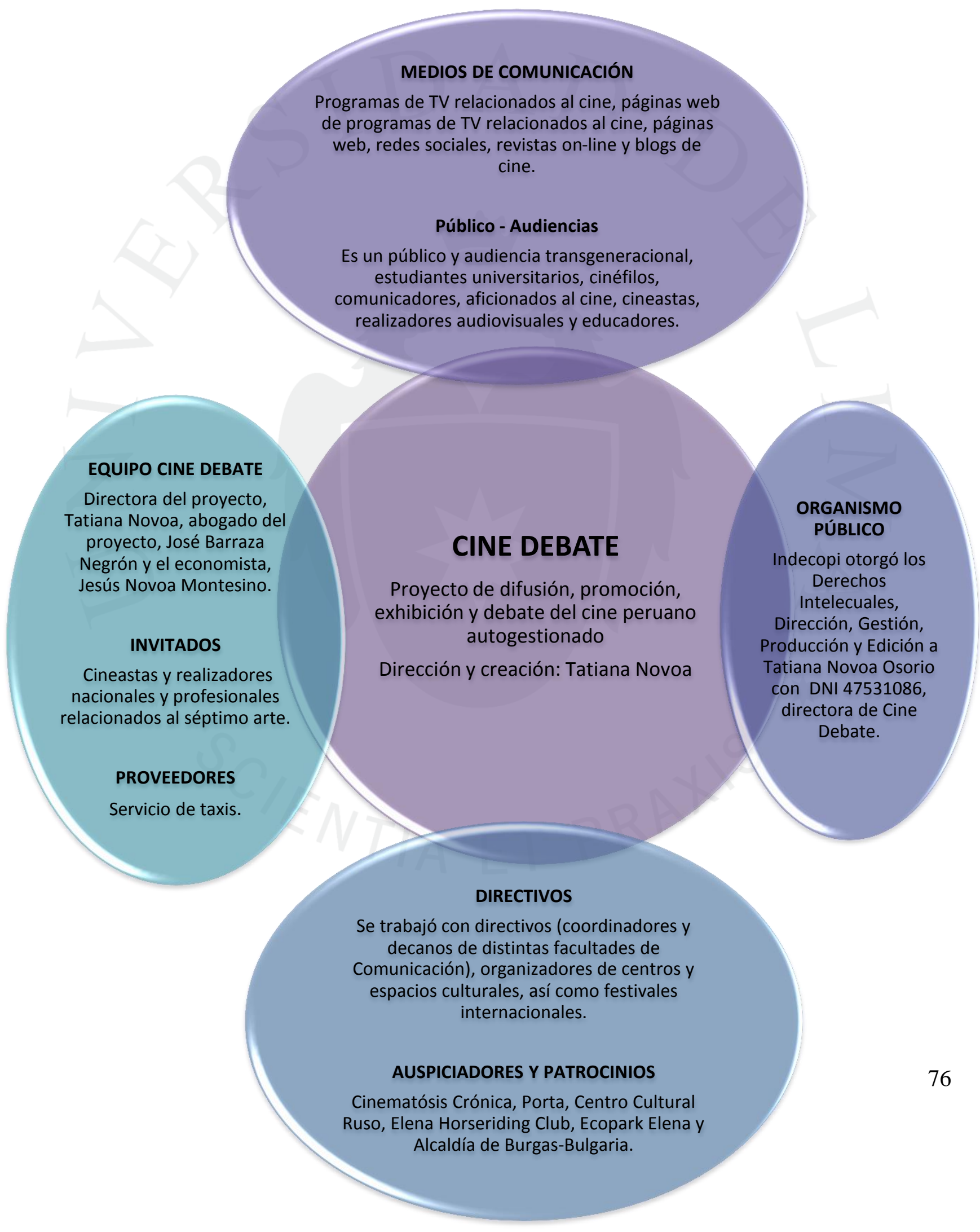




\section{Cine Debate y los Festivales Internacionales}

Cine Debate en su búsqueda de formar alianzas y llevar el formato que presenta, a otros países, llega en diciembre del 2015 al "Festival Internacional del Nuevo Cine Latinoamericano", el cual se lleva a cabo en la Habana, Cuba desde el 3 de diciembre de 1979, fecha de fundación a cargo de su presidente y gestor, Alfredo Guevara.

En un principio el "Festival Internacional del Nuevo Cine Latinoamericano", tenía como objetivo difundir las obras cinematográficas que contribuían, desde su significación y de sus valores artísticos, al enriquecimiento y reafirmación de la identidad cultural latinoamericana y caribeña."

Actualmente, realizan concursos de ficción, documental y animación, óperas primas, guiones inéditos y carteles. Además, se organizan encuentros y seminarios sobre diversos temas de interés cultural y, en especial, cinematográfico. Finalmente, el programa del festival acoge una amplia y representativa muestra de cine contemporáneo proveniente del resto del mundo.

Bajo la modalidad "Encuentros Cinematográficos de Interés Cultural” se descentraliza el Festival de la Habana, dando la oportunidad a que los cineastas difundan sus trabajos audiovisuales en distintas ciudades de Cuba. Es ahí que Cine Debate se hace presente con su formato y lleva a cabo el evento "Dreadlocks Story", el 27 de diciembre del 2015 a las 21 horas. 
La cineasta, directora y productora del documental "Dreadlocks Story", Linda Aïnouche, franco-canadiense apostó por el formato de Cine Debate para presentarse en el boulevard de la ciudad de Cienfuegos, provincia de Cienfuegos, Cuba. En donde, el evento obtuvo una buena aceptación por parte del público asistente. Se logró la retroalimentación entre los participantes y asistentes al evento; sumado a ello, se crearon contactos entre Linda Aïnouche y el público, dado que querían que se exhiba su documental en otras provincias o espacios culturales y ofrecían encargarse de la producción que se requería. Por su parte, la cineasta, amante de los documentales, prometió empezar un documental sobre la influencia de la cultura cubana en el mundo.

En esta oportunidad Cine Debate se hizo al aire libre, resaltando ante todo su formato y estructura que gustó mucho como experiencia en conocimiento y cinematografía.

Cabe resaltar, que el evento no pudo haber sido posible sin el apoyo del segundo jefe de Aduana de la provincia de Cienfuegos en 2015, Jesús Novoa Montesino, quién facilitó las medidas de seguridad y el apoyo del evento. Más adelante, se explicará la sostenibilidad y financiamiento del proyecto en el festival.

Por último, el proyecto no podría haberse presentado y ser seleccionado en el festival sino fuera por tener una estrategia de gestión cultural que respalda su formalidad a través del área legal, el área de comunicación que promueve los objetivos culturales, artísticos y sociales que son la esencia del proyecto, y el área de planeación que genera respaldo hacia el proyecto. 


\section{Sostenibilidad del proyecto}

La sostenibilidad de Cine Debate se da gracias al financiamiento que se ha venido realizando desde el 2014. Para ello, se ha tomado en cuenta el presupuesto, el cual incluye todos los rubros que necesita el proyecto para su ejecución, teniendo en cuenta los costos reales.

Por otro lado, se diversificaron las fuentes de financiamiento y siempre se maneja una estrategia de obtención de recursos. Aquí compartimos el esquema de fuentes de financiamiento del proyecto desde el 2014 hasta la actualidad:

Año 2014: La sostenibilidad a través del financiamiento se basa en el modelo de la autogestión.

Del año 2015 al 2017: La sostenibilidad y financiamiento se basa en el modelo de la gestión cultural.

\section{Figura 6: Año 2014: I Edición (abril-junio)}

\section{Costos:}

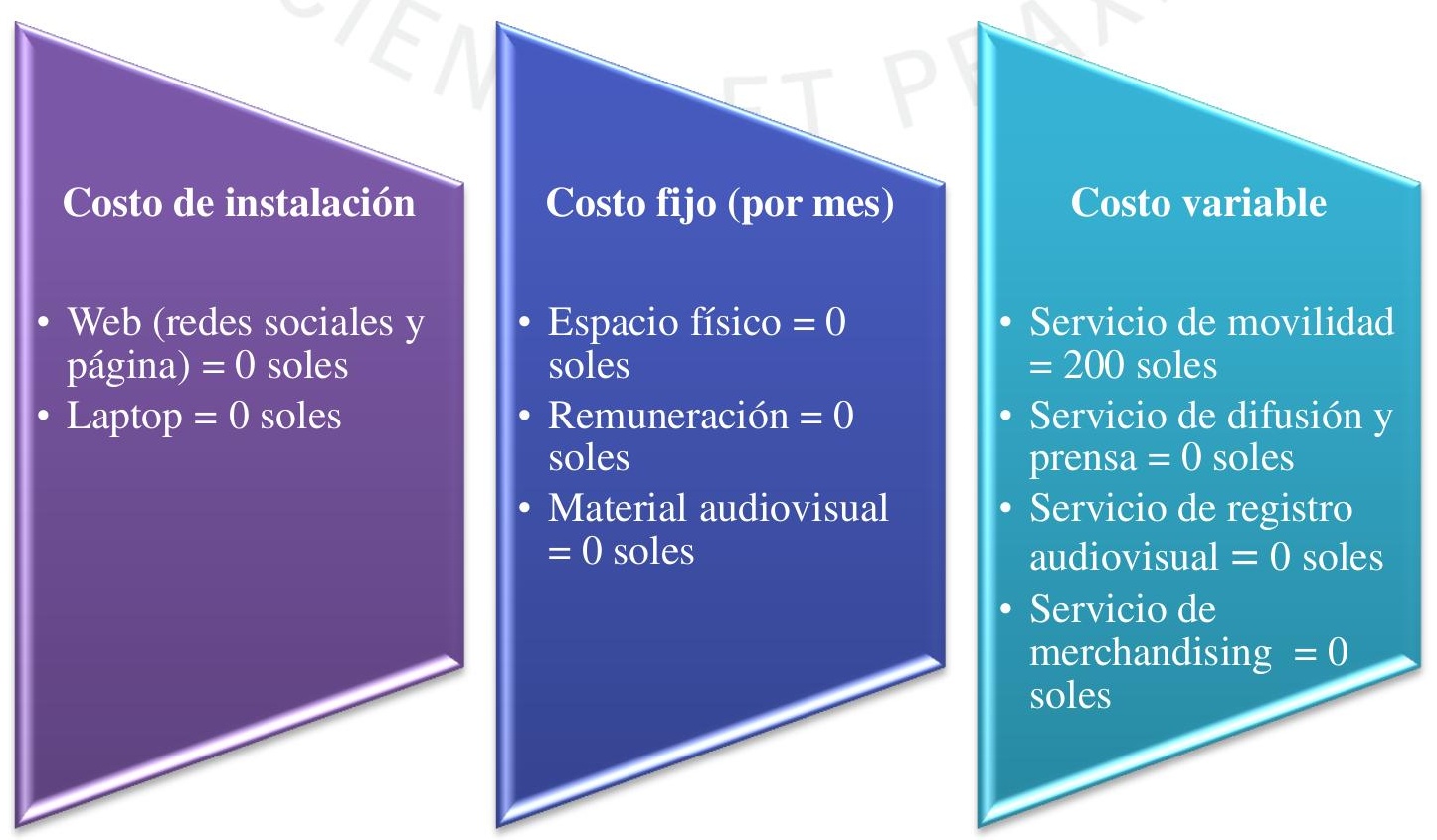




\section{Fuentes de financiamiento:}

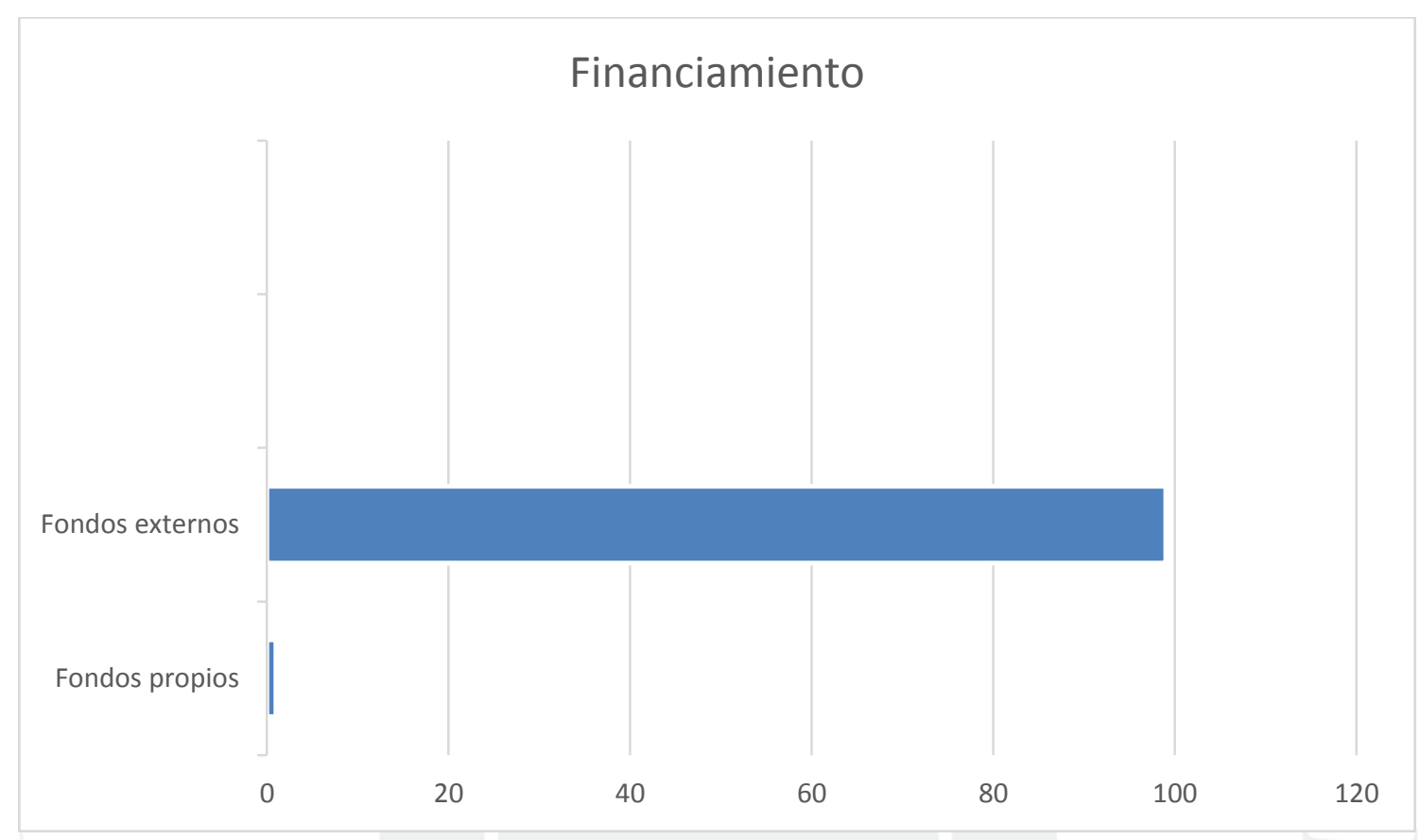

En relación a los fondos propios corresponden a la inversión por parte de la dirección del proyecto:

- Costo de instalación - 0 soles

- Costo variable/servicio de movilidad - 200 soles

En el caso de los fondos externos corresponden a los auspicios y patrocinios en la primera temporada de Cine Debate, los cuales fueron:

- El Portal Producciones - auspicio que cubrió el costo fijo de material audiovisual y el costo variable de registro audiovisual.

- Cinematosis (empresa de difusión de cine) - auspicio que cubrió el costo variable de la difusión y prensa.

- Revista Dedo Medio - auspicio que cubrió el costo variable de la difusión y prensa. 
- Empresa de mochilas y maletas Porta - auspicio que cubrió el costo variable de merchandising.

- Ventana Indiscreta de la Universidad de Lima - patrocinio en recurso material y servicio que cubrió el costo fijo del espacio físico.

Figura 7: Año 2014: II Edición (noviembre-diciembre)

\section{Costos:}
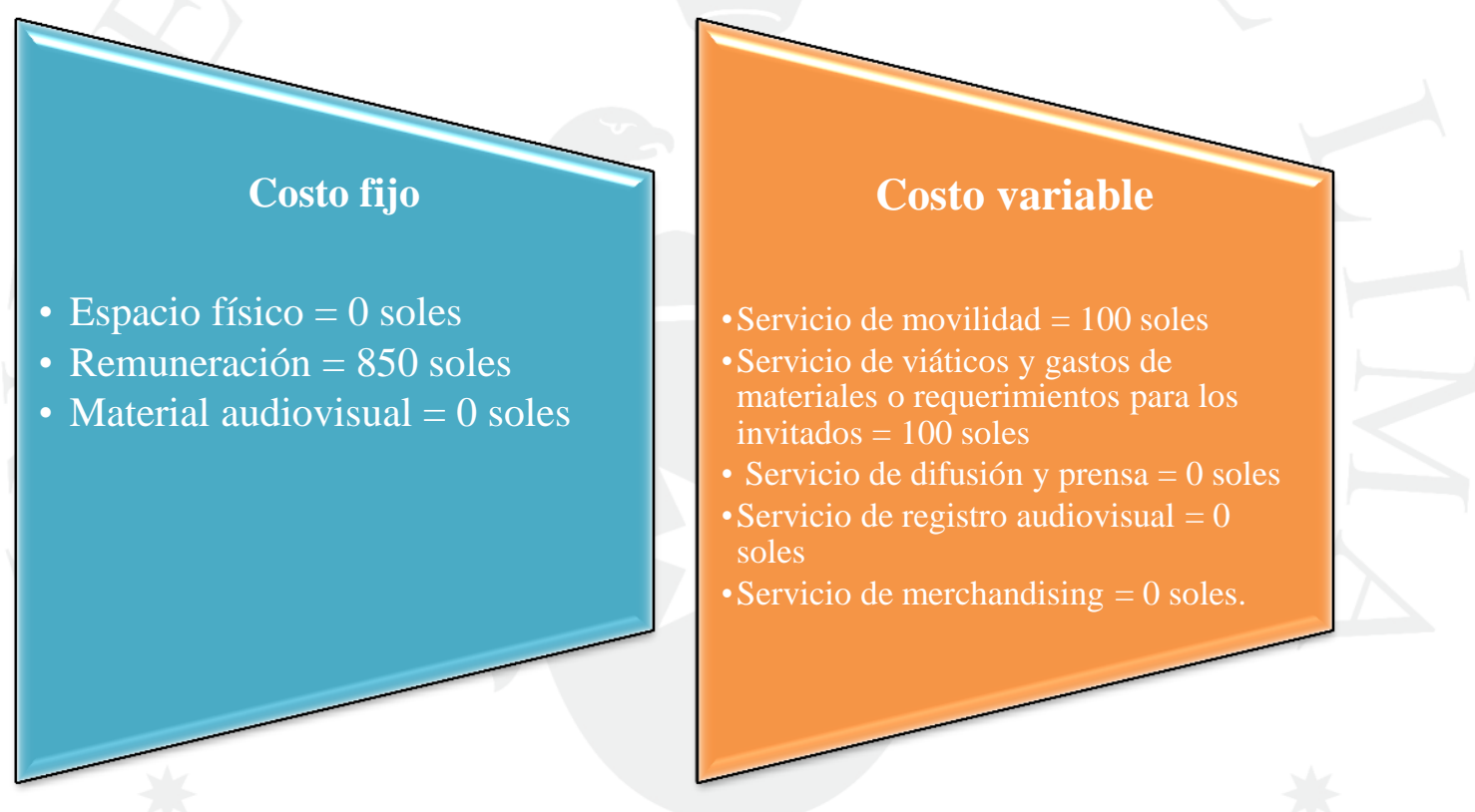


\section{Fuentes de Financiamiento:}

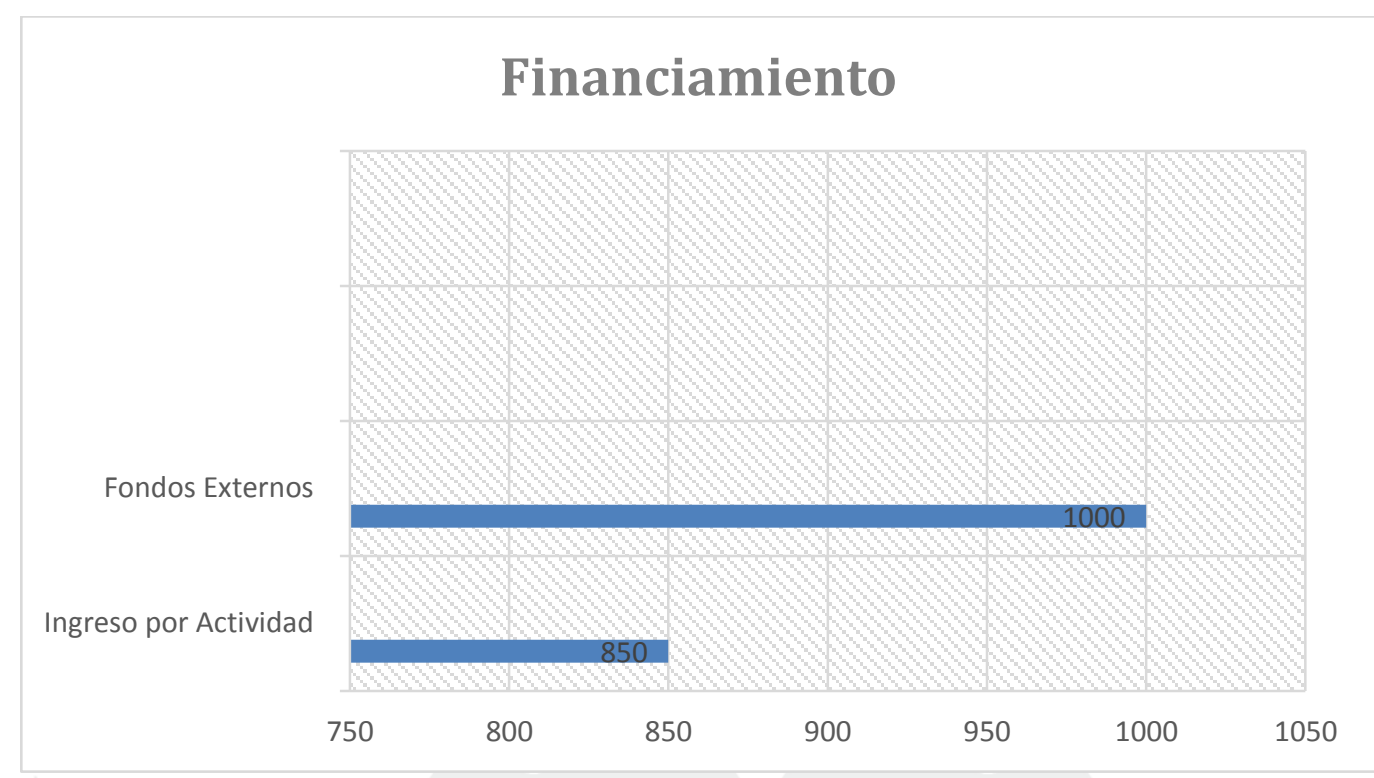

Surge el ingreso por actividad, que corresponde a la remuneración por el servicio profesional que se le otorga a la dirección del proyecto por parte de la empresa o entidad privada.

- Costo fijo - 850 soles.

En el caso de los fondos externos se contó con auspicios y patrocinios:

- El Portal Producciones - auspicio que cubrió el costo fijo de material audiovisual y el costo variable de registro audiovisual.

- Cinematosis (empresa de difusión de Cine) - auspicio que cubrió el costo variable de la difusión y prensa.

- Revista Dedo Medio - auspicio que cubrió el costo variable de la difusión y prensa.

- Empresa de mochilas y maletas Porta - auspicio que cubrió el costo variable de merchandising.

- Universidad del Pacífico - patrocinio en recurso material y servicio que cubrió el costo fijo del espacio físico. 
Figura 8: Año 2015: III Edición (septiembre-diciembre)

\section{Costos:}
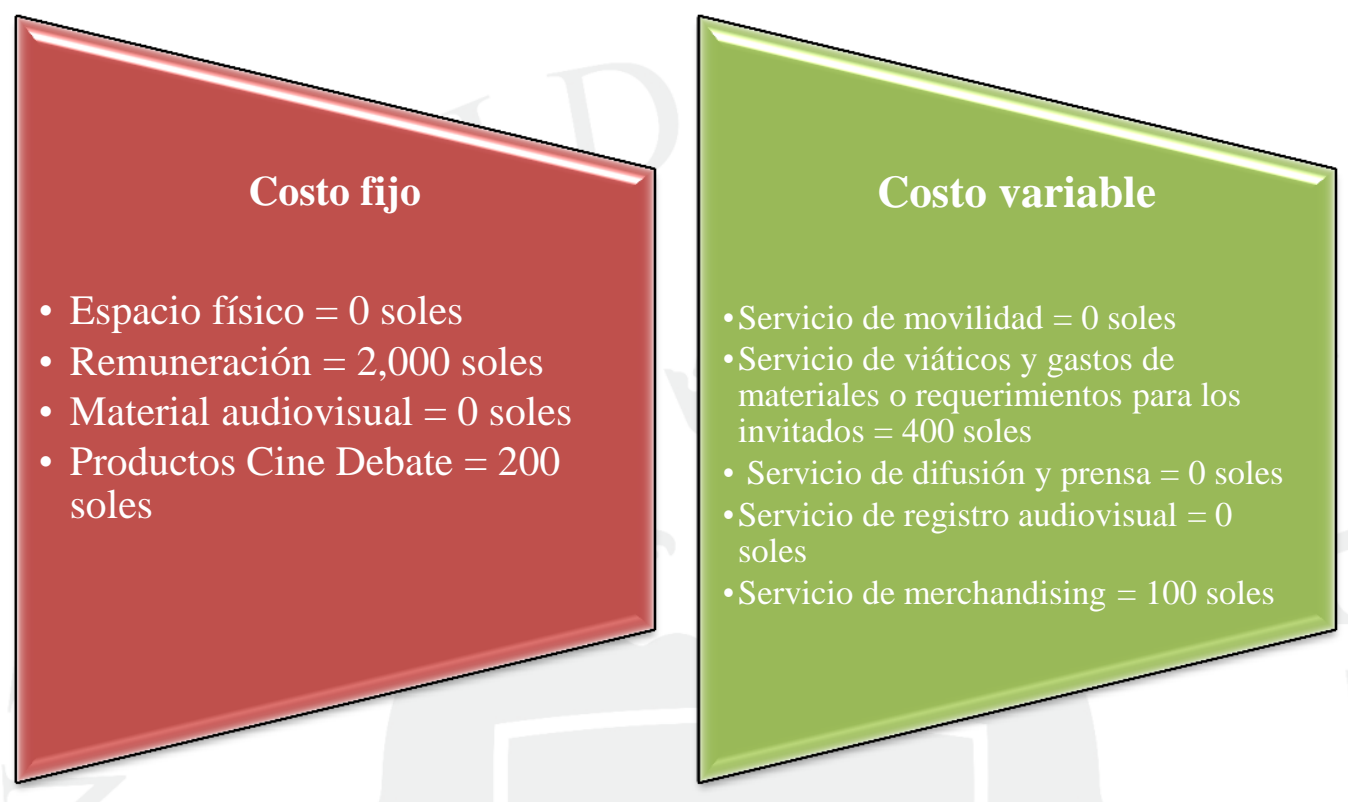

\section{Fuentes de financiamiento:}

\section{Financiamiento}

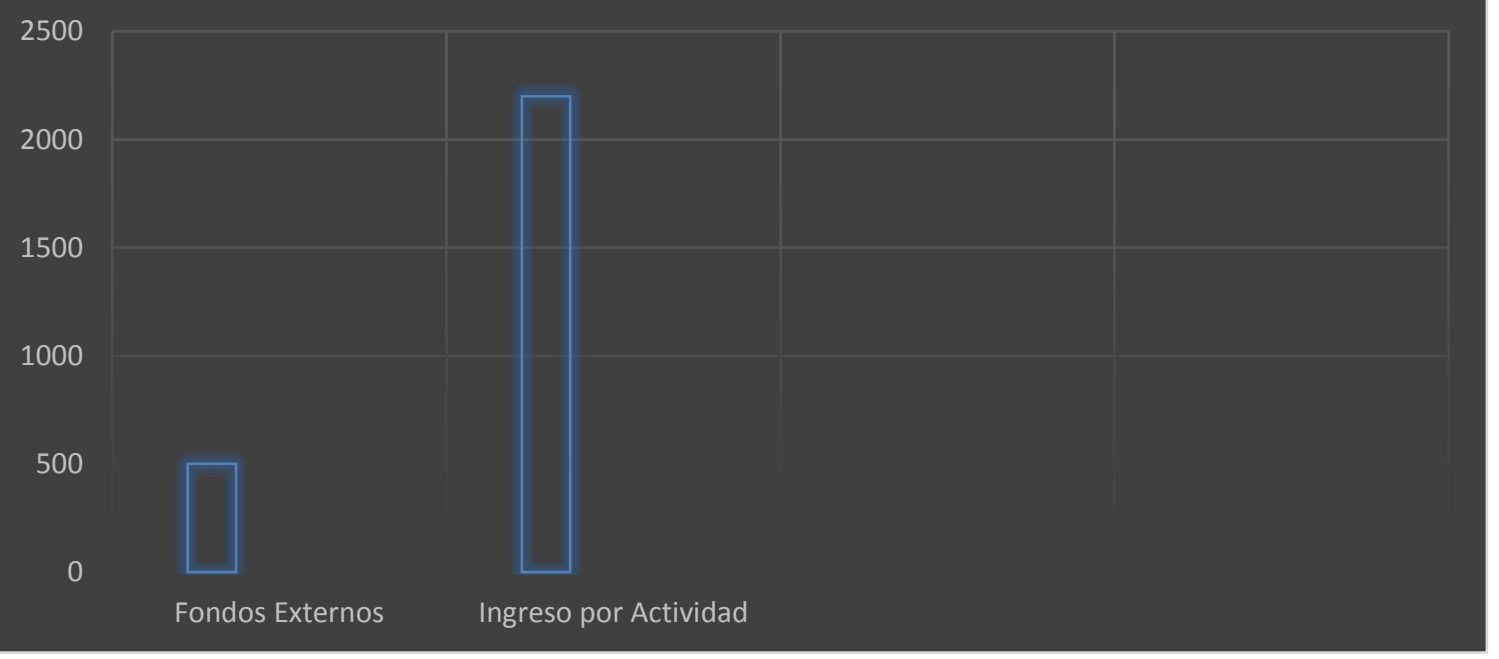


En el rubro de ingreso por actividad, se añade a la remuneración por el servicio profesional que se le otorga a la dirección del proyecto por parte de la empresa o entidad privada, la venta de productos Cine Debate en el espacio físico y on-line. En consecuencia, se cubren dos costos fijos.

- Remuneración: 2,000 soles

- Productos Cine Debate: 200 soles

En el caso de los fondos externos se contó con auspicios y patrocinios:

- Cinematosis (empresa de difusión de cine) - auspicio que cubrió el costo variable de la difusión y prensa.

- Empresa de mochilas y maletas Porta - auspicio que cubrió el costo variable de merchandising.

- Universidad de Ciencias y Artes de Latinoamérica UCAL - patrocinio en recurso material y servicio que cubrió el costo fijo del espacio físico y el costo variable del servicio de movilidad. 
Figura 9: Año 2015: Cine Debate y el Festival Internacional del Nuevo Cine Latinoamericano de la Habana
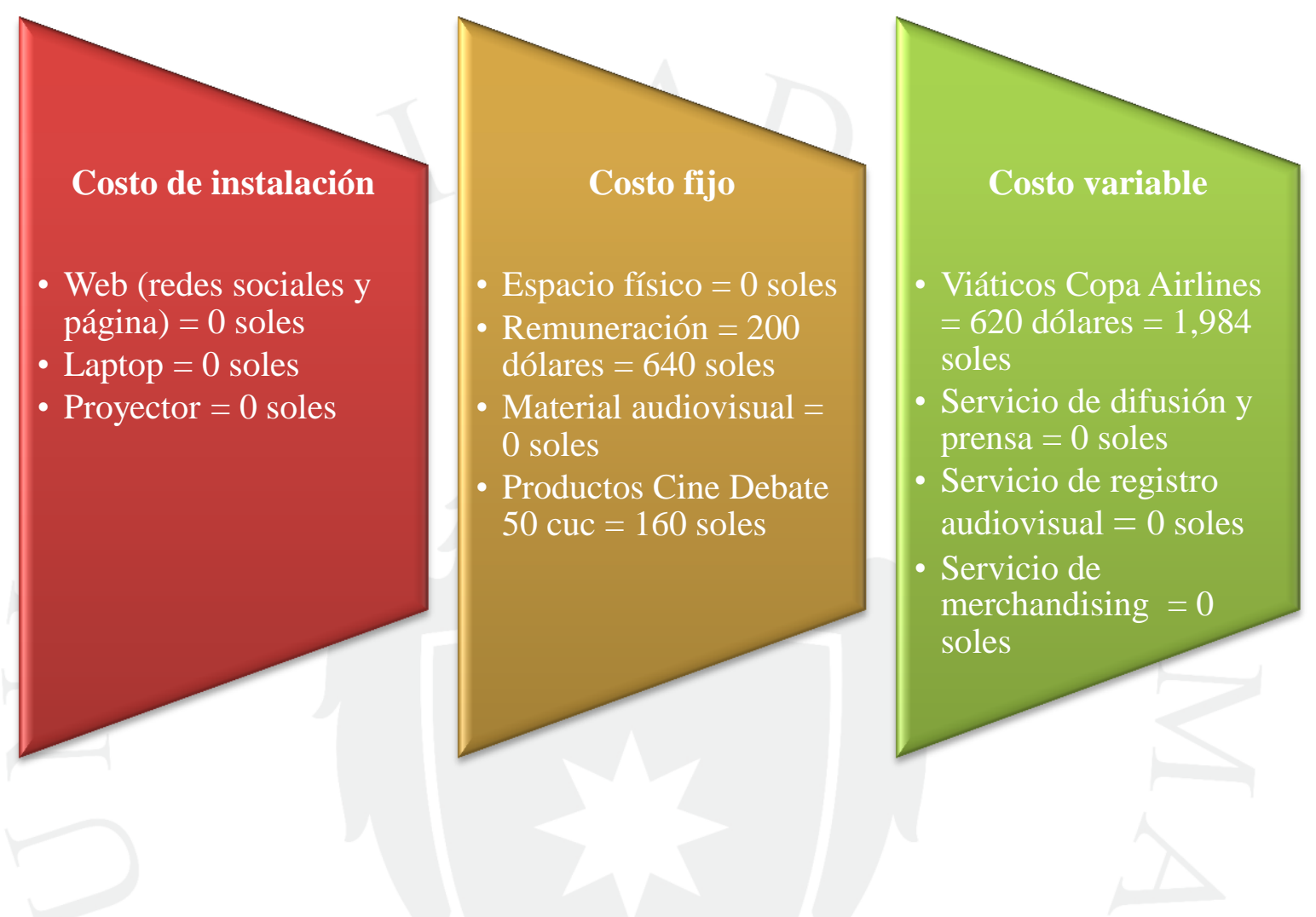

Fuentes de financiamiento:

\section{Financiamiento}

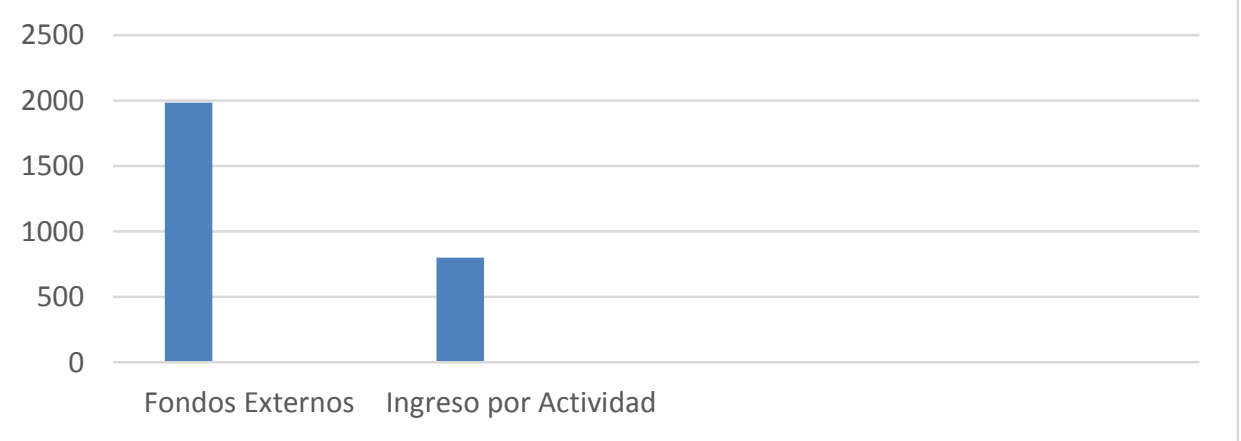


En el rubro de ingreso por actividad, se cuenta con la remuneración por el servicio profesional que se le otorga a la dirección del proyecto por parte de la junta organizadora del Festival, la venta de productos Cine Debate en el espacio físico y on-line. De donde, se cubre dos costos fijos.

- Remuneración: 640 soles

- Productos Cine Debate: 160 soles

En el caso de los fondos externos se contó con auspicios y patrocinios:

- Jefatura de la Aduana de Cienfuegos, Cuba - auspicio que cubrió el costo variable de la difusión y prensa.

- Empresa de mochilas y maletas Porta - auspicio que cubrió el costo variable de merchandising.

- Junta Organizadora del Festival Internacional del Nuevo Cine Latinoamericano de la Habana - patrocinio en recurso material y servicio que cubrió el costo fijo del espacio físico y el costo variable del servicio de viáticos. 
Figura 10: Año 2016: IV Edición (enero-septiembre)

\section{Costos:}
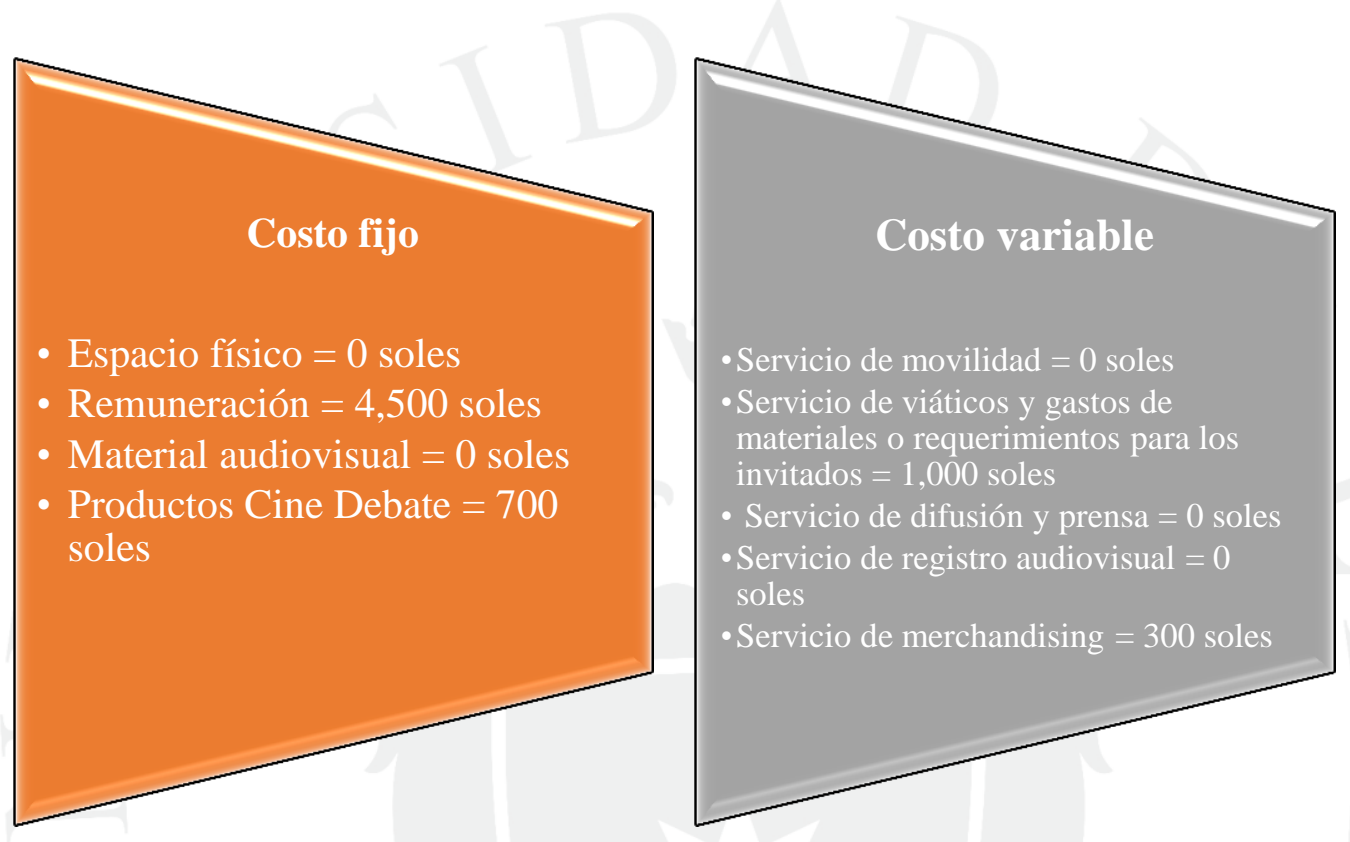

\section{Fuente de financiamiento:}

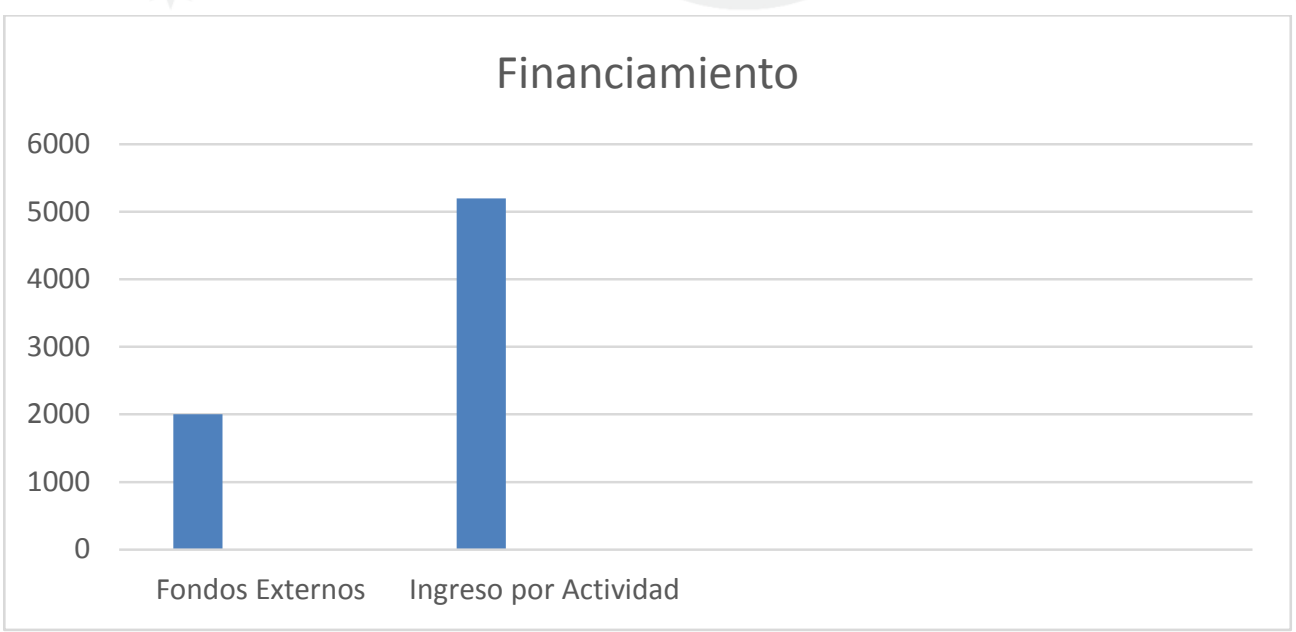


En el rubro de ingreso por actividad, se cuenta con la remuneración por el servicio profesional que se le otorga a la dirección del proyecto por parte de la entidad privada, la venta de productos Cine Debate en el espacio físico y on-line. De donde, se cubre dos costos fijos.

- Remuneración: 4,500 soles

- Productos Cine Debate: 700 soles

En el caso de los fondos externos se contó con auspicios y patrocinios:

- Cinematosis Crónica - auspicio que cubrió el costo variable de la difusión y prensa.

- Empresa de mochilas y maletas Porta - auspicio que cubrió el costo variable de merchandising.

- Universidad de Ciencias y Arte de Latinoamérica UCAL - patrocinio en recurso material y servicio que cubrió el costo fijo del espacio físico y el costo variable del servicio de movilidad. 
Figura 11: Año 2017: V Edición (noviembre)

\section{Costos:}
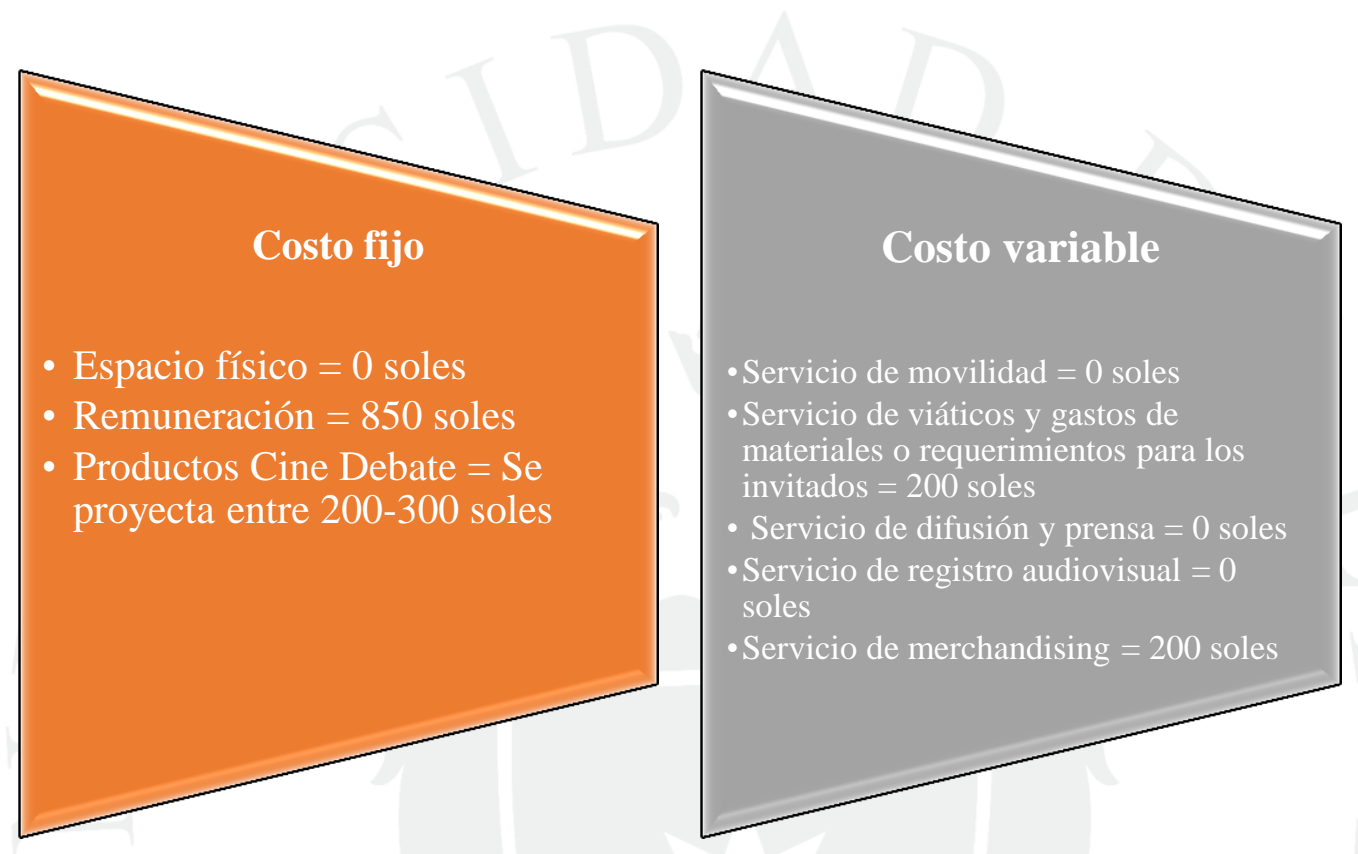

Fuentes de financiamiento:

Con respecto al ingreso por actividad, se cuenta con la remuneración por el servicio profesional que se le otorga a la dirección del proyecto por parte de la entidad privada, la venta de productos Cine Debate en el espacio físico y on-line. De donde, se cubrirán dos costos fijos.

- Remuneración: 850 soles

- Productos Cine Debate: 200-300 soles

En el caso de los fondos externos se contará con auspicios y patrocinios: 
- Academia de Artes Marciales Black Dragons - auspicio que cubrirá el costo variable de la difusión y prensa.

- Empresa de mochilas y maletas Porta - auspicio que cubrirá el costo variable de merchandising.

- Centro Cultural Ruso - patrocinio en recurso material y servicio que cubrirá el costo fijo del espacio físico y el costo variable del servicio de movilidad.

Figura 12: Año 2018: VI Edición (Bulgaria, mayo-julio)

\section{Costos:}
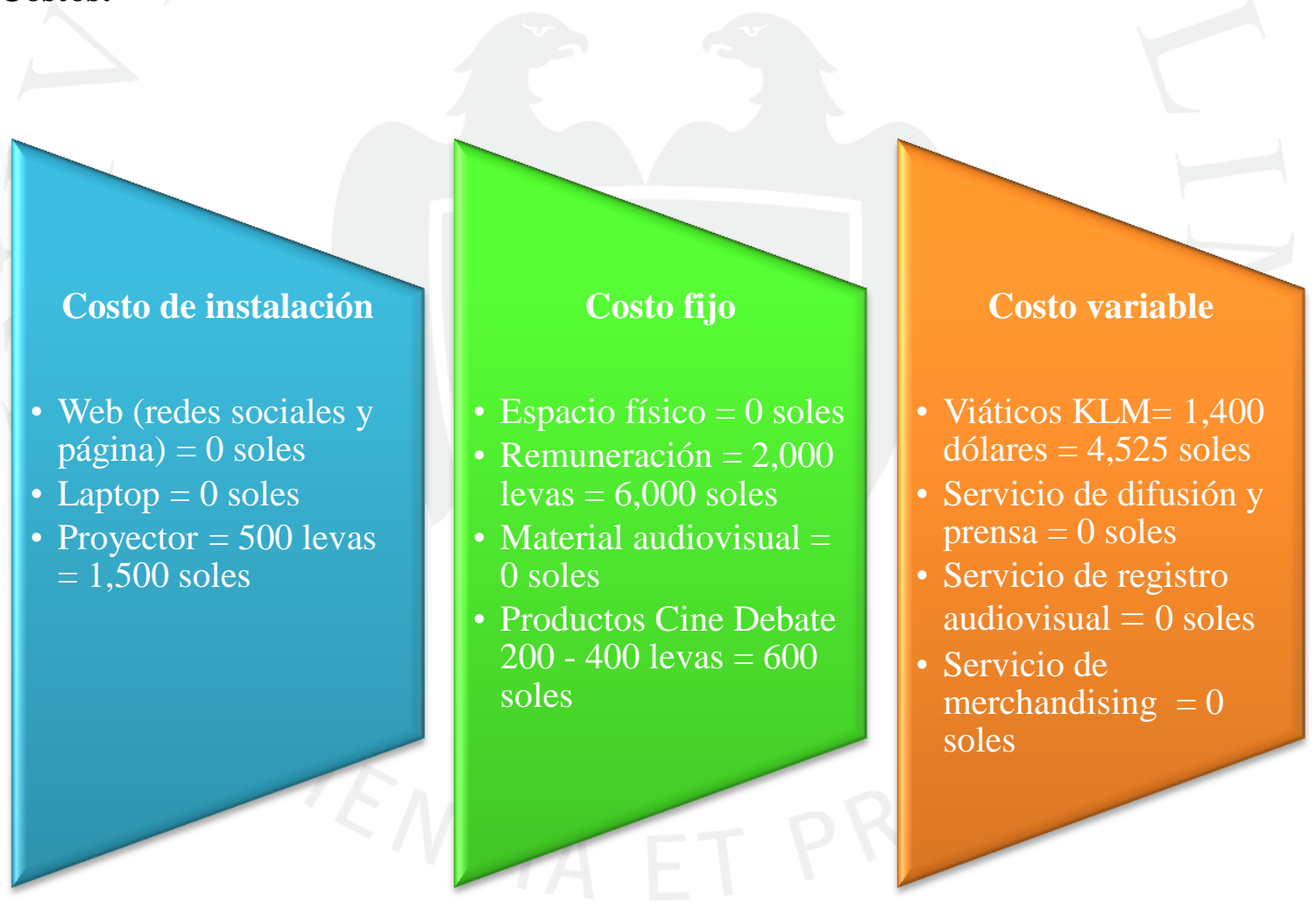


\section{Fuentes de financiamiento:}

Con respecto al ingreso por actividad, se cuenta con la remuneración por el servicio profesional que se le otorga a la dirección del proyecto por parte de la entidad privada, la venta de productos Cine Debate en el espacio físico y on-line. De donde, se cubrirán dos costos fijos.

- Remuneración: 6,000 soles

- Productos Cine Debate: 600 - 1,200 soles.

En el caso de los fondos externos se contará con auspicios y patrocinios:

- Elena Horseriding Club y Ecopark Elena - auspicio que cubrirá el costo variable de la difusión y prensa.

- Empresa de mochilas y maletas Porta - auspicio que cubrirá el costo variable de merchandising.

- Tatiana Novoa Cultural Home - patrocinio en recurso material y servicio que cubrirá el costo fijo del espacio físico y el costo variable del servicio de movilidad. 


\section{Lecciones aprendidas}

Cine Debate es un proyecto que está vigente desde el 2014 hasta la actualidad gracias a la aceptación, respaldo y apoyo del público asistente, el “público Cine Debate”. Sin ellos no habría proyecto, ya que está dirigido a ellos. Es importante mencionar, que siempre se ha realizado estrategias de comunicación orientadas hacia nuestro público objetivo.

La esencia de un formato como el de Cine Debate goza de preferencia, cabe mencionar, que su referente es el cineclub y la experiencia cinematográfica que ofrece. Para reforzar el argumento, se citará las palabras del profesor Atilio Bonilla, encargado del Cine Club de Letras de la UNMSM, "mientras siga existiendo un auditorio que quiera ver cine, cultura, arte y educación, la esencia del cineclubismo no se perderá”.

El proyecto Cine Debate permite seleccionar los filmes y dar a conocer su rol dentro de la sociedad, así como analizar sus objetivos artísticos, culturales, sociales, educativos; es el cine visto como expresión independiente, de autor, alternativo y que no cuenta con ningún apoyo por parte del Estado. El proyecto genera un espacio con un auditorio que quiere y puede ver esta nueva propuesta, la cual ha ganado un sitio en el imaginario cinematográfico actual.

Cabe resaltar, que, desde su incubación, el proyecto planteó la siguiente reflexión por parte de la directora, Tatiana Novoa:

"Invité a mi evento piloto a un cineasta independiente que conocí actuando para un cortometraje en la Escuela de Cine, llamado André Ponce, se fue del Perú porque nadie apoyaba sus ideas "locas" para hacer cine y logra migrar a España hace más de siete años, ahí sus ideas "locas" son aceptadas por su casa de estudio, la Escuela de Cinematografía de 
Cataluña, la cual luego de otorgarle una beca a la excelencia académica, lo pone en contacto con casas productoras, con la única condición de que grabe dos proyectos de cortos, uno de ellos con actores españoles y en escenarios de la región, el siguiente se lo financian por completo con este tipo de incentivos y motivaciones. Él me dijo, el Estado no hace nada, tienes que apostar por ser tú, ser independiente, conseguir tus contactos, auspiciadores, productores, hacer intercambio de auspicios, hacer cine implica hacer el amor todos los días con tu proyecto hasta que quede embarazado y pueda dar a luz, y, es más, de ti depende que alumbre en un hospital o en una clínica."

A través de esta reflexión, el cineasta André Ponce quiere retratar que todos pueden gestionar por su cuenta, buscar apoyo y estar constantemente creando maneras de explotar todos los recursos posibles para ejecutar el proyecto o producto audiovisual que se quiera llevar a cabo. Cine Debate ha demostrado que, si se puede hacer visible el valor del cine peruano autogestionado en el campo social, cultural, artístico y educativo, puesto que revalora el arte y rol cinematográfico peruano. ¿Qué medio concientizó a una nación sobre un régimen político? ¿Qué medio creó formas de ver otras culturas? ¿Qué medio creó la imagen en movimiento y la saturación de colores y el efecto sepia o blanco y negro para recordar el pasado, que nos permite conocer el presente y proyectarnos al futuro? ¿Qué medio logró erradicar tasas de analfabetismo y a la vez impulsó un aprendizaje bilingüe a través de la imagen? Las respuestas recaen en una sola palabra: cine. Hablamos, debatimos, proyectamos, difundimos, exhibimos, promovemos y promocionamos el cine peruano autogestionado, esto es, ha sido, y será siempre Cine Debate.

Cine Debate, en sus tres años de existencia, ha organizado eventos en donde se ha exhibido, difundido, debatido, discutido y promovido más de cuarenta realizaciones audiovisuales, veinte 
cortometrajes, veinte largometrajes y nuevas propuestas cinematográficas como el fotocorto, logrando sus objetivos establecidos.

A través de las redes sociales de Cine Debate se ha difundido, en estos tres años, noticias, eventos y artículos relacionados al cine peruano autogestionado como parte de su apoyo a este tipo de cine y, además, cumpliendo sus objetivos como proyecto educativo, social, artístico y cultural.

Son tres años de aprendizaje sobre la importancia de apostar por la gestión cultural como herramienta de sostenibilidad, financiamiento y networking para seguir creciendo como proyecto y lograr un óptimo rol dentro de la sociedad.

Cine Debate logra la difusión, exhibición, discusión y promoción del cine peruano autogestionado en el extranjero. Teniendo como experiencia su participación en el Festival Internacional del Nuevo Cine Latinoamericano de la Habana, bajo la modalidad de Encuentros Cinematográficos de Interés Cultural (2015). En la actualidad, se planea llevar a cabo una temporada del proyecto Cine Debate en la ciudad de Varna, Bulgaria (2018), el cual contará con el apoyo de la alcaldía de la ciudad y dos empresas privadas, Elena Ecopark y Elena Horseriding.

Desde que empezó el proyecto hasta la actualidad se ha promovido el conocimiento del cine peruano autogestionado a través del aprendizaje significativo que pone en práctica en cada uno de sus eventos.

En los eventos Cine Debate se revalora la experiencia cinematográfica y se logra que el público asistente, a través de dinámicas integrativas, participativas y generativas, se involucre con el proyecto ya sea, dando un "me gusta" en las redes sociales o compartiendo contenido, 
apoyando en la producción del evento, haciendo una compra de los productos que se ofrecen de merchandising, en los eventos como de manera on-line, con una crítica constructiva, con la presencia, siendo parte de una red de contactos que busca hacer más por el cine peruano autogestionado.

Cine Debate logra el reconocimiento de Indecopi como aliado en la formalidad del proyecto, característica indispensable para la gestión que viene desarrollando el proyecto a nivel nacional e internacional, dado que, al tener derechos intelectuales respaldados con bases legales y estatales, permiten que el proyecto pueda realizarse en todo el territorio nacional y en el extranjero.

El proyecto se convierte en un referente para otros espacios culturales y académicos, que han comenzado a interesarse por difundir, promover y dar a conocer más del cine peruano autogestionado. 


\section{Lista de referencias}

Amount, Jacques. (2006). Diccionario Teórico y Crítico de Cine. Buenos Aires: La Marca.

Arzola, Sonia. (1995). Historia del Cineclubismo en Venezuela. En: Comunicación: Estudios Venezolanos de Comunicación. N: 89.

Bedoya, Ricardo. (2002). Una Historia Intermitente. En: Libros \& Artes. Revista de Cultura de la Biblioteca Nacional del Perú. N: 2.

Bedoya, Ricardo. (2009). El Cine Sonoro en el Perú. Lima: Universidad de Lima, Fondo Editorial.

Bedoya, Ricardo. (2009). El Cine Silente en el Perú. Lima: Universidad de Lima, Fondo Editorial.

Bedoya, Ricardo. (2009). El Cine Club de Lima. En: Contratexto. Revista de la Facultad de Comunicación de la Universidad de Lima. N: 17.

Bayardó, Rubens. (2009). Los Gestores Culturales: Nuevos Profesionales del Sector Cultural. En: Summa Humanitatis Revista Interdisciplinaria del Departamento de Humanidades PUCP. Vol. 3, Número 1.

Bernández, Jorge. (2003). La Profesión de la Gestión Cultural: Definiciones y Retos. En: Boletín de Gestión Cultural. Número 4.

Contreras, Óscar. (2009). ¿Qué es el Cine Peruano? En: Ventana Indiscreta. Revista de cine de la Facultad de Comunicación de la Universidad de Lima, N: 1.

Fernández, Diana. (1998). El cineclubismo y los contornos socioculturales del cine de autor. En: Voces y Cultura. Revista de Comunicación. N: 13.

Gubern, Román. (1998). Historia del Cine. Barcelona: Lumen, Quinta Edición.

Gómez Pérez, Rafael. (1996). La Cultura a través del Cine. Madrid: Eds. Del Drac.

Godoy, Mauricio. (2012). Lo Autobiográfico dentro del Documental Contemporáneo en el Perú. Tesis (Licenciatura), Facultad de Ciencias y Artes de la Comunicación, Pontificia Universidad Católica del Perú. 
García Canclini, Néstor. (1987). Políticas Culturales y Crisis de Desarrollo: Un Balance Latinoamericano. En: Políticas Culturales en América Latina. México D.F.: Grijalbo.

Hennebelle, Guy. (1977). Los Cinemas Nacionales contra el Imperialismo de Hollywood: Nuevas Tendencias del Cine Mundial, 1960-1975. Valencia: Fernando Torres.

Hendrickx, Nathalia. (2010). Perspectivas y Posibilidades de Crecimiento del Cine Peruano en el Contexto Mundial. Tesis (Magíster), Facultad de Ciencias y Artes de la Comunicación, Pontificia Universidad Católica del Perú.

León, Isaac. (2014). Tierras Bravas. Lima: Universidad de Lima.

León, Isaac. (1996). Diccionario Temático del Cine Peruano. En: La Gran Ilusión. Revista de Cine. N: 6.

Manrique, Mónica. (2001). El Cine Club Cuzco. Tesis (Licenciatura), Facultad de Comunicación, Universidad de Lima.

Martinell, Alfons. (1999) Los Agentes ante los Nuevos Retos de la Gestión Cultural. En: Revista Iberoamericana de Educación. Número 20.

Mena, José Luis. (2004). Diccionario de Cine. Madrid: Edimat Libros.

Piault, Marc Henri. (2002). Antropología y Cine. Madrid: Cátedra.

Schuman, Peter B. (1987). Historia del Cine Latinoamericano. Buenos Aires: Legasa.

Shohat, Elle. (2002). Multiculturalismo, Cine y Medios de Comunicación: Crítica del Pensamiento Eurocéntrico. Barcelona: Paidós Ibérica.

Tamayo, Augusto. (2008). Financiamiento, Distribución y Marketing del Cine Peruano. Lima: Universidad de Lima, Fondo Editorial.

Uroz, José. (1999). Historia y Cine. Alicante: Universidad de Alicante.

Varios autores. (2010). Cine Peruano Contemporáneo. En: Ventana Indiscreta. Revista de cine de la Facultad de Comunicación de la Universidad de Lima, N: 3.

Varios autores. (2011). Cineclubes en Lima: Presente y Futuro. En: Ventana Indiscreta. Revista de cine de la Facultad de Comunicación de la Universidad de Lima, N: 5.

Varios autores. (2012). Cine independiente. En: Ventana Indiscreta. Revista de cine de la Facultad de Comunicación de la Universidad de Lima, N: 7. 


\section{Anexos}

\section{Anexo I: Documento INDECOPI}

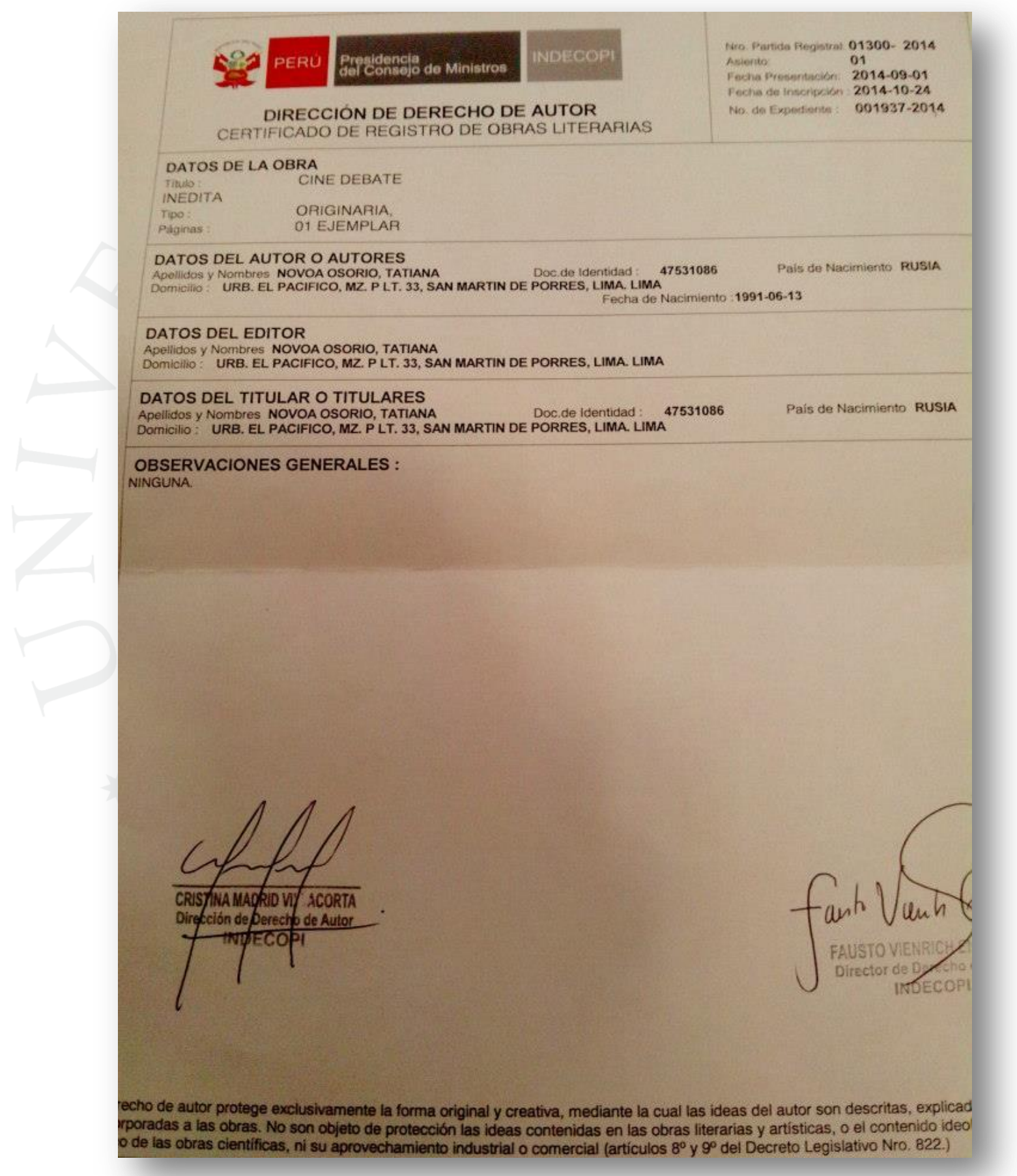




\section{Anexo II: Fotografías de los eventos Cine Debate}

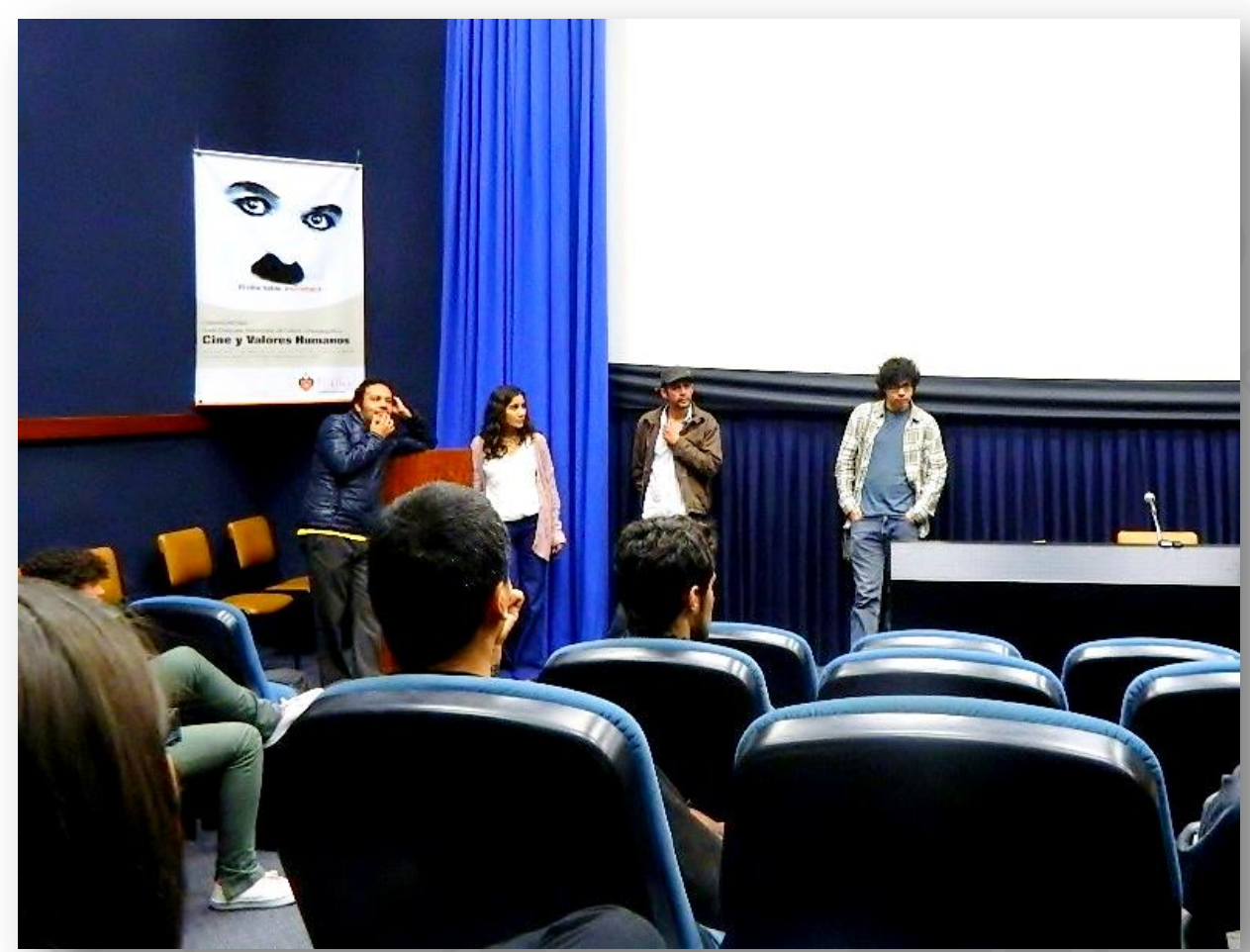

Evento piloto de Cine Debate”. Los realizadores invitados: Carlos Sánchez, Sofía Velásquez, André Ponce y Alejandro Small. 


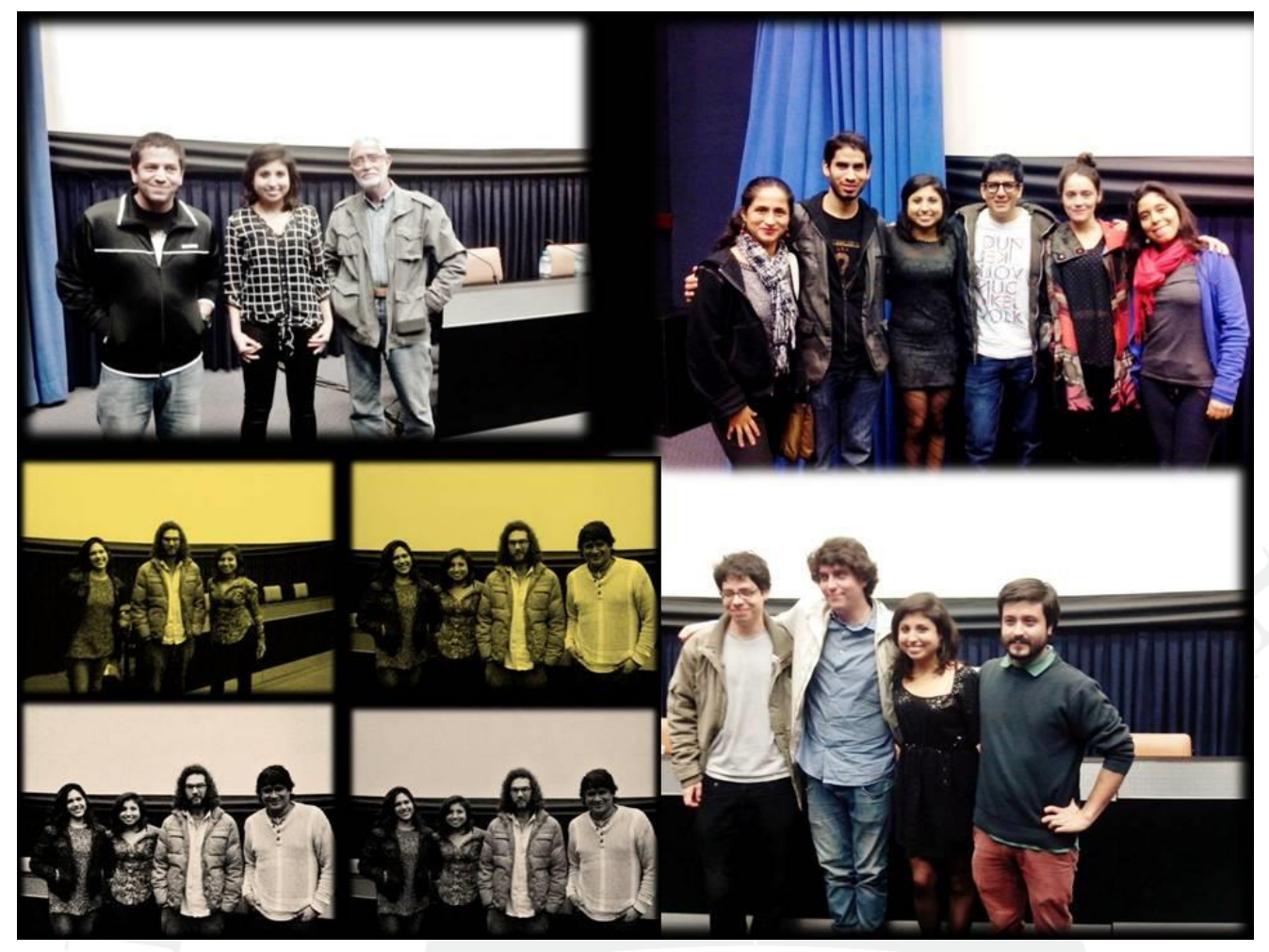

Collage de fotografías. Invitados de Cine Debate. 


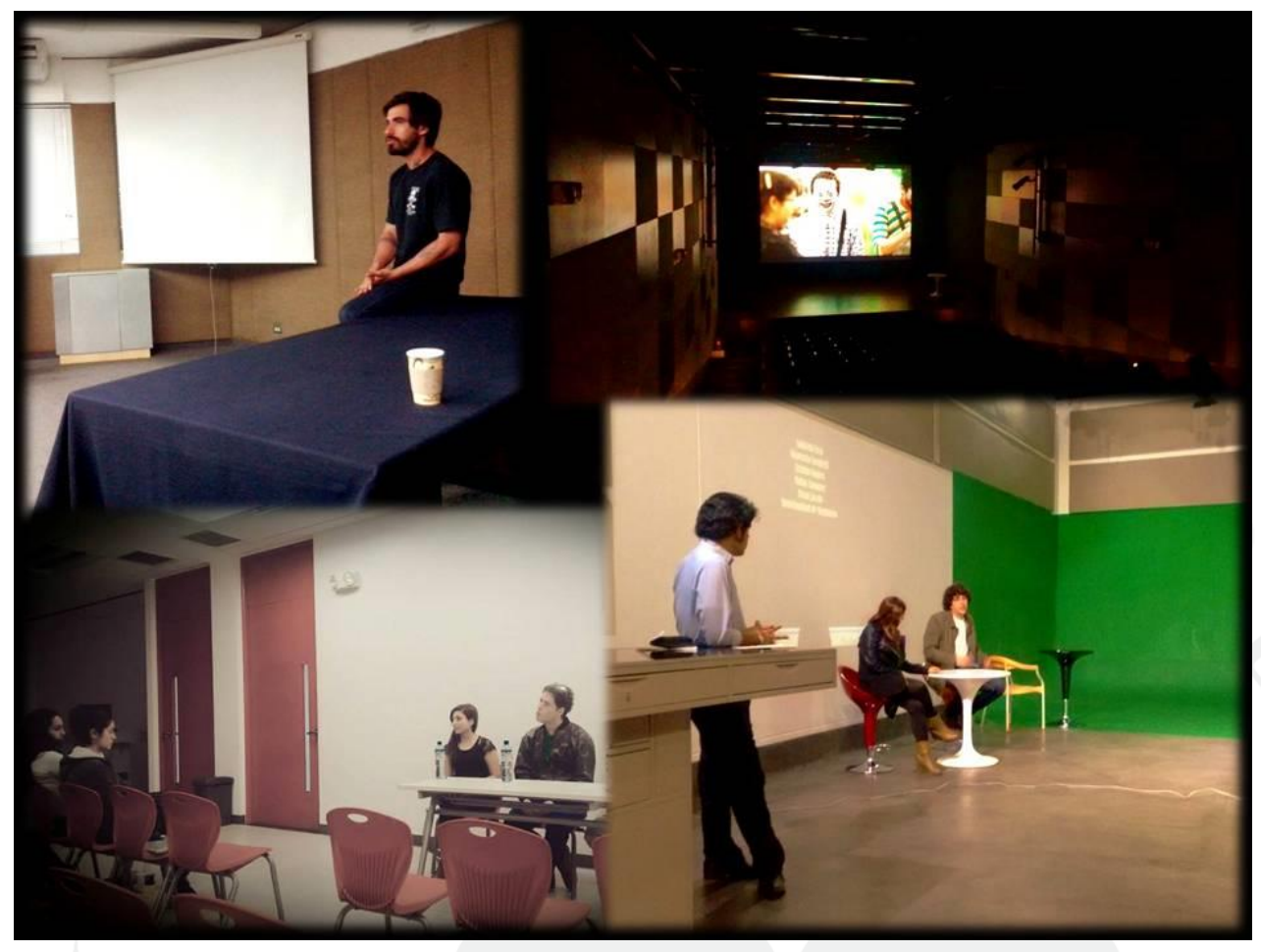

Collage de fotografías. Invitados de Cine Debate. 


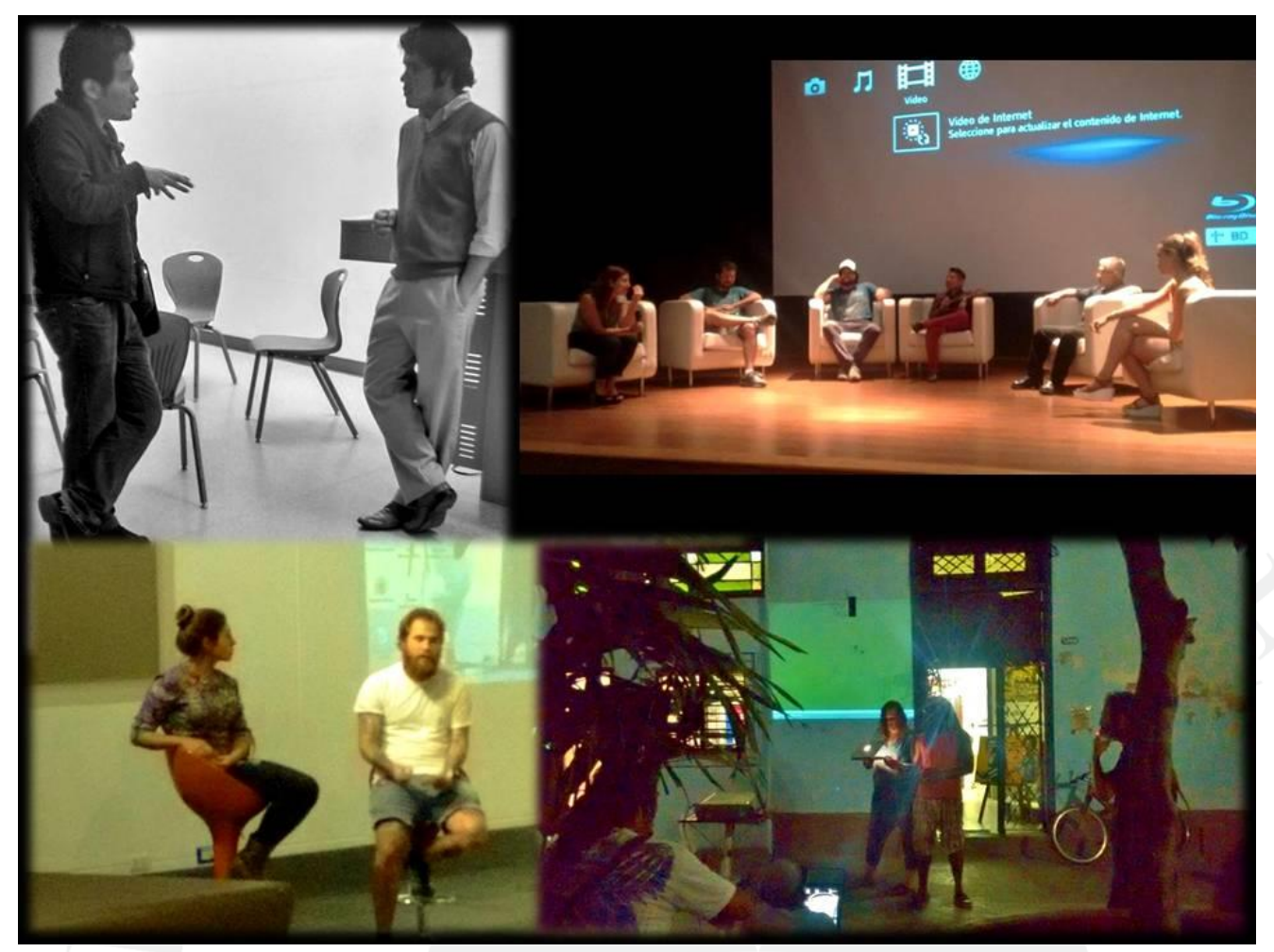

Collage de fotografías. Invitados de Cine Debate. 


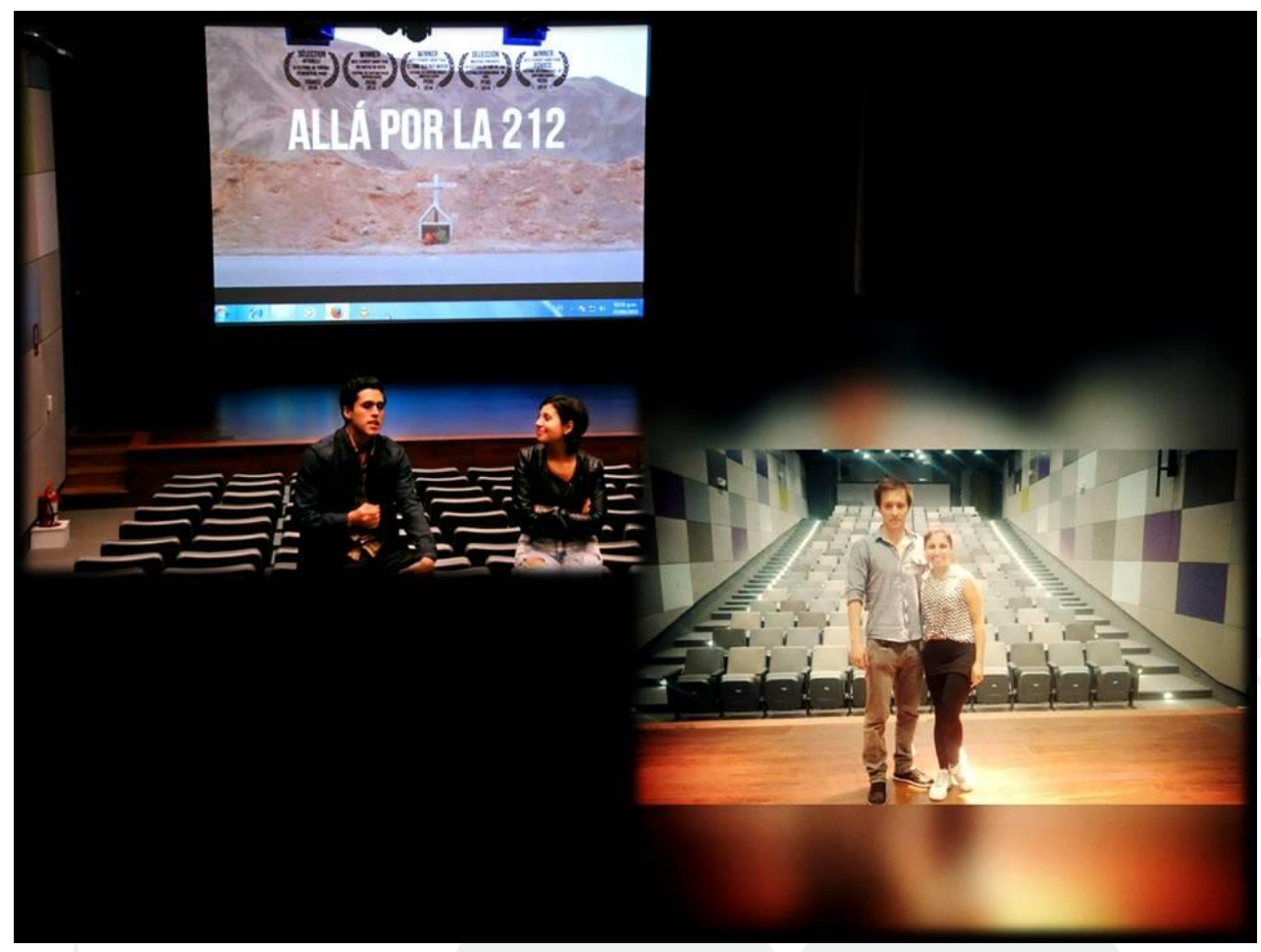

Collage de fotografías. Invitados de Cine Debate. 


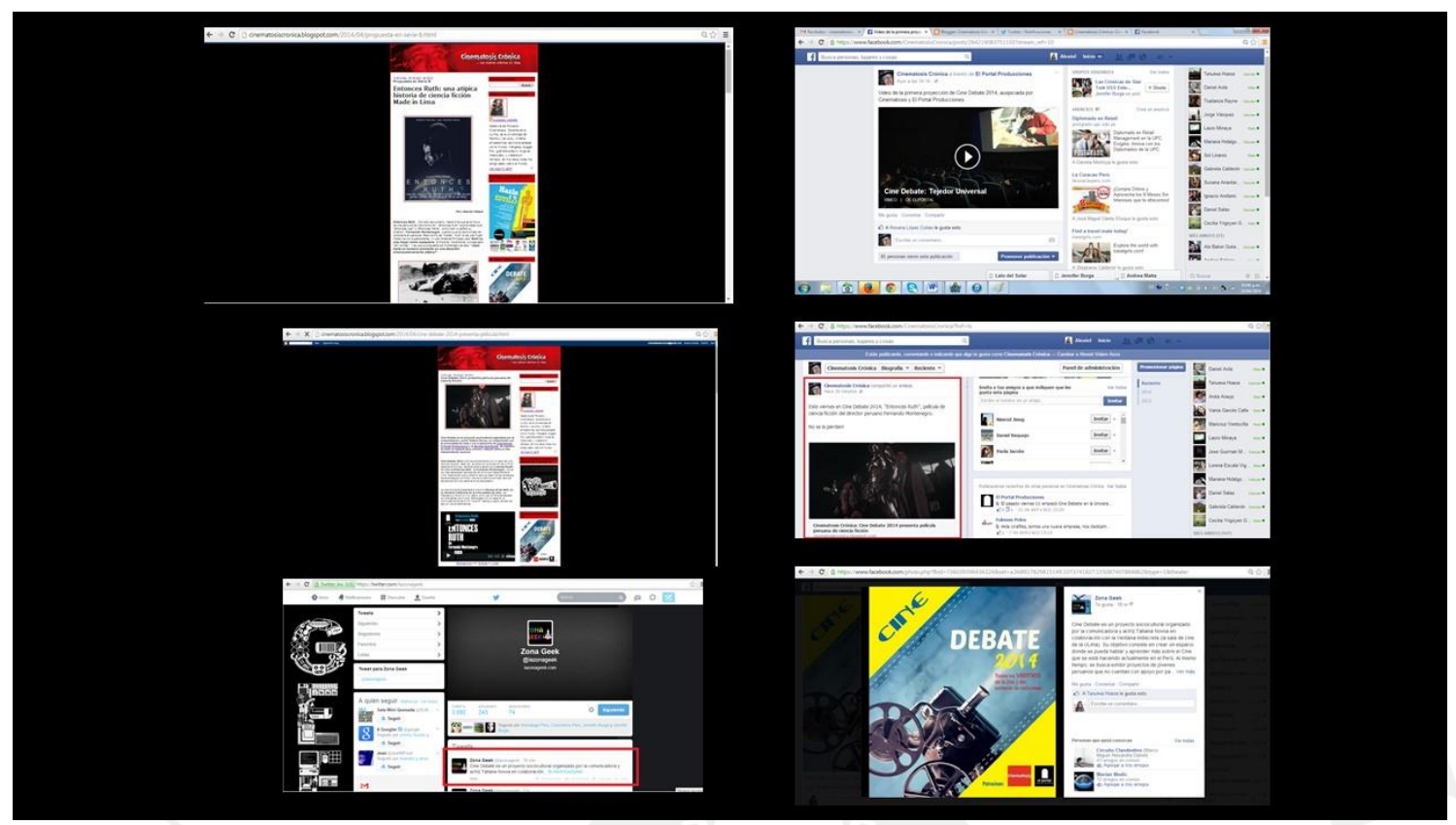

Collage de fotografías. Difusión de Cine Debate.

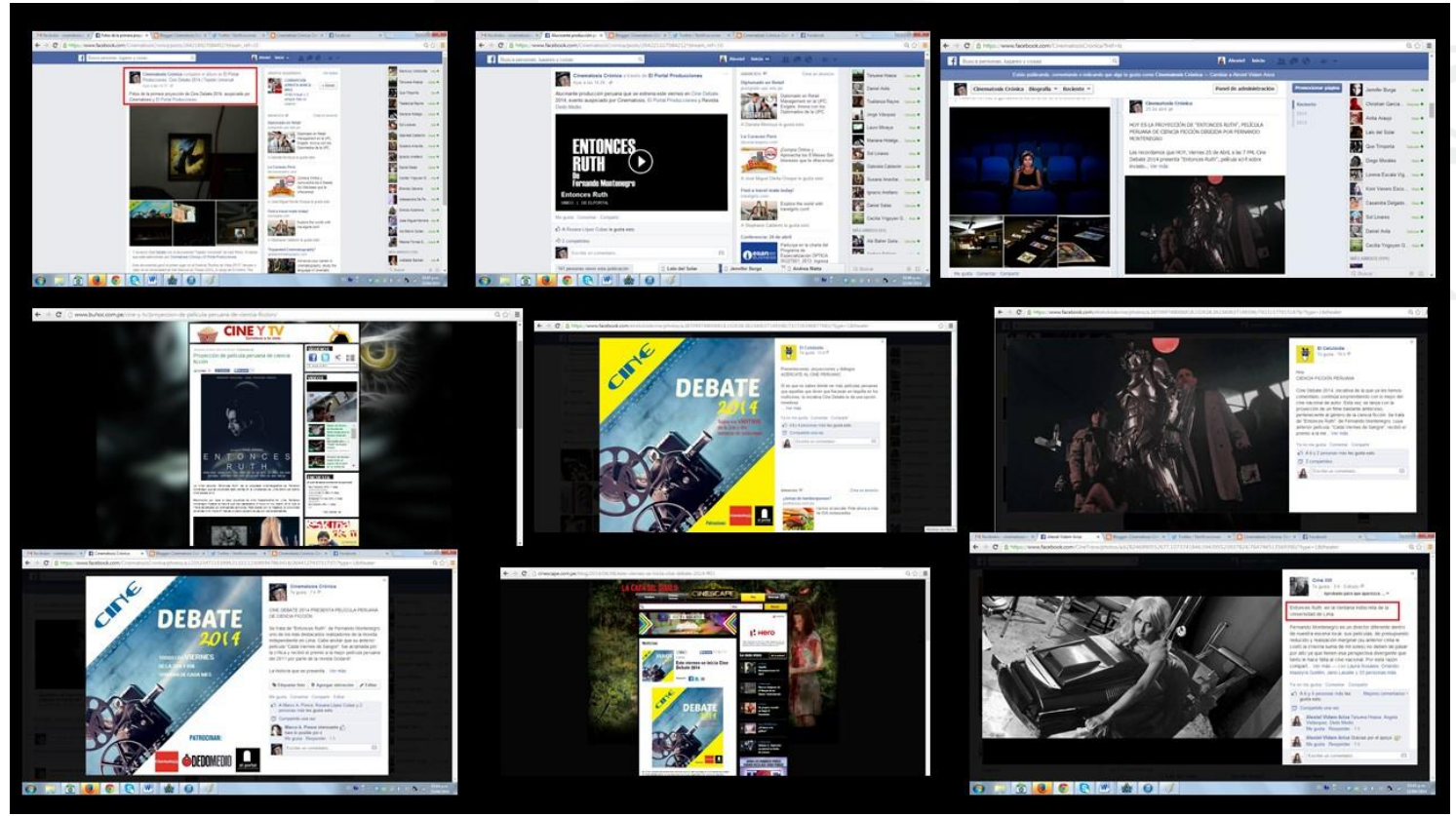




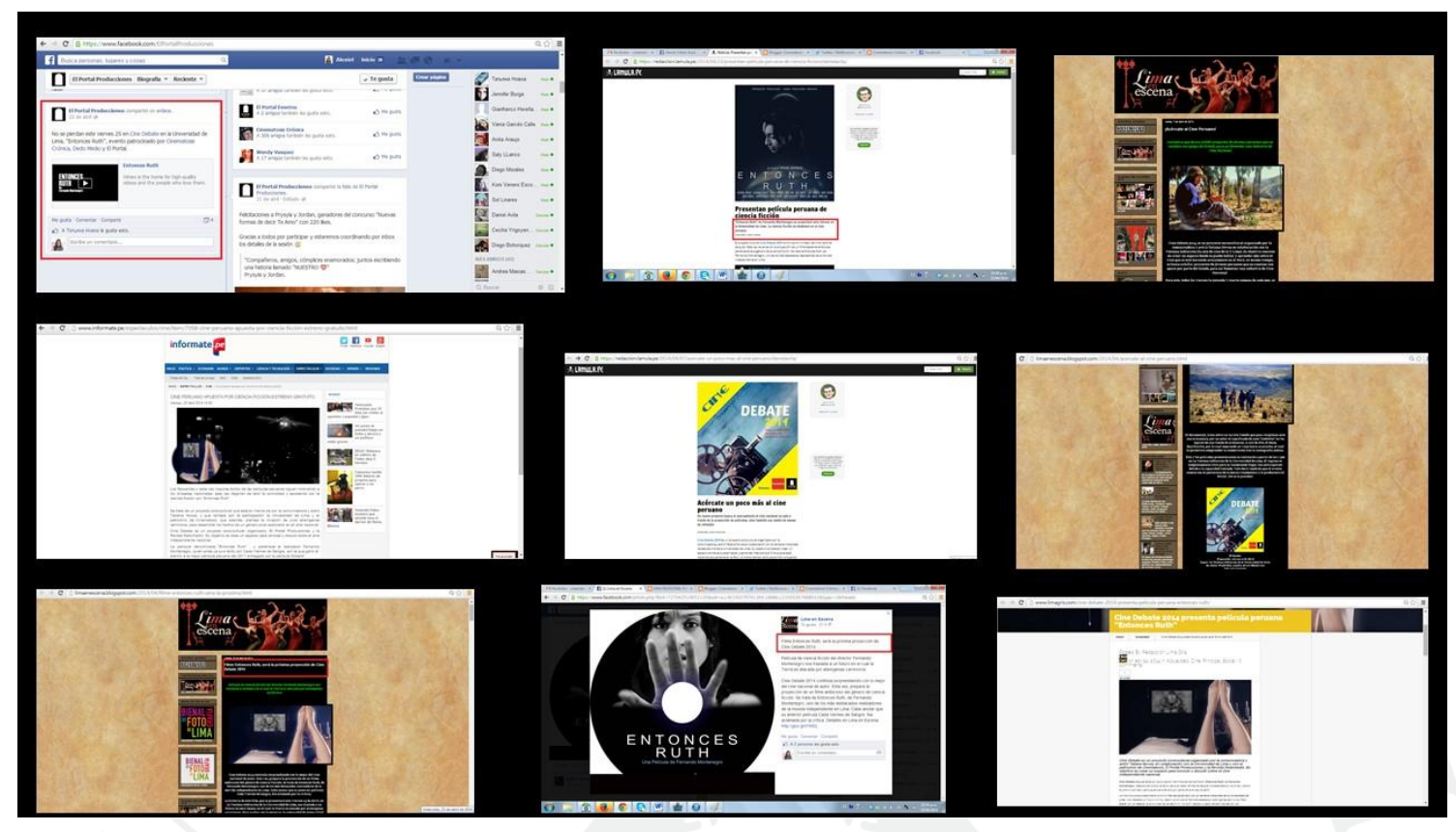

Collage de fotografías. Difusión de Cine Debate.

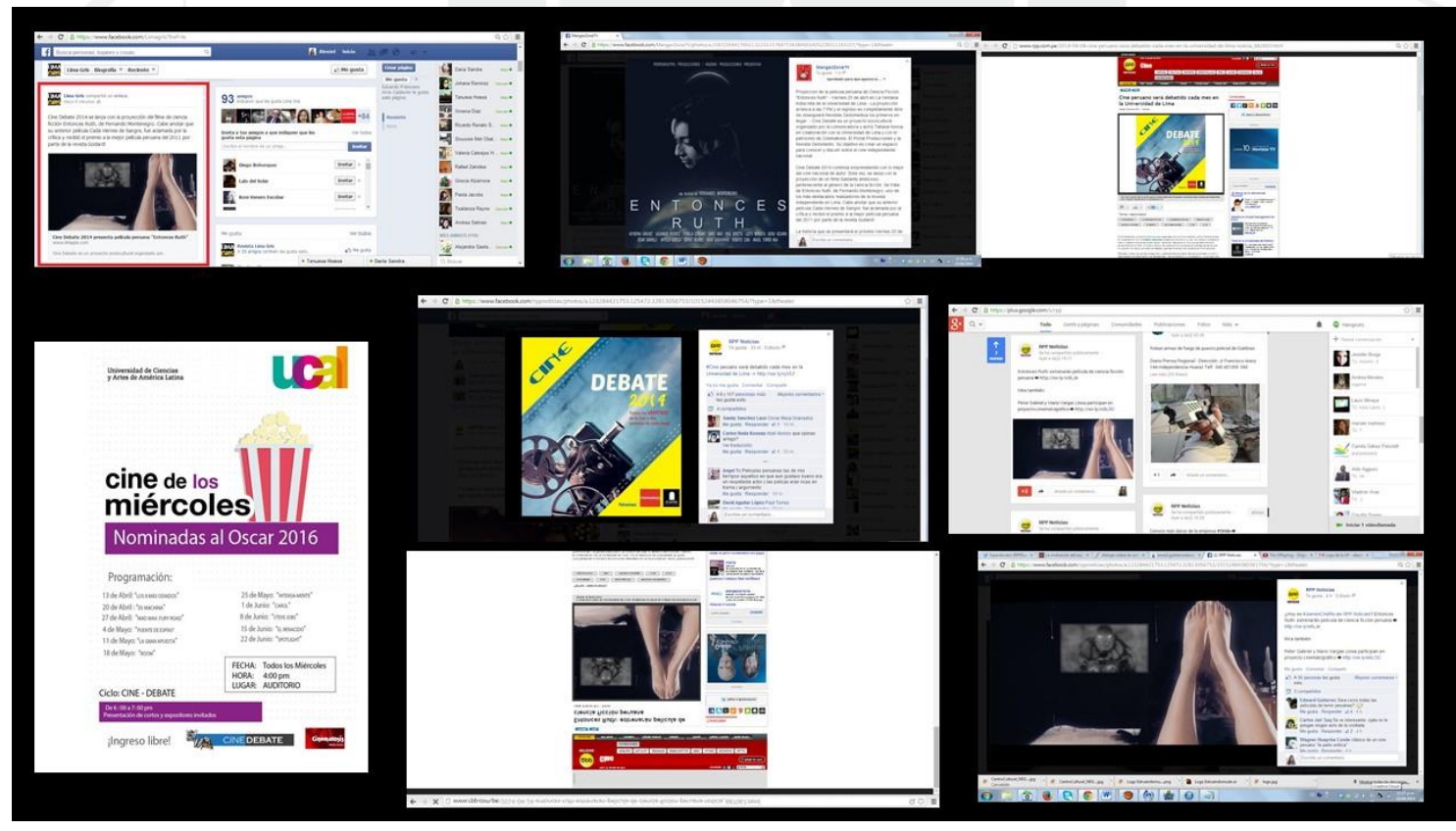




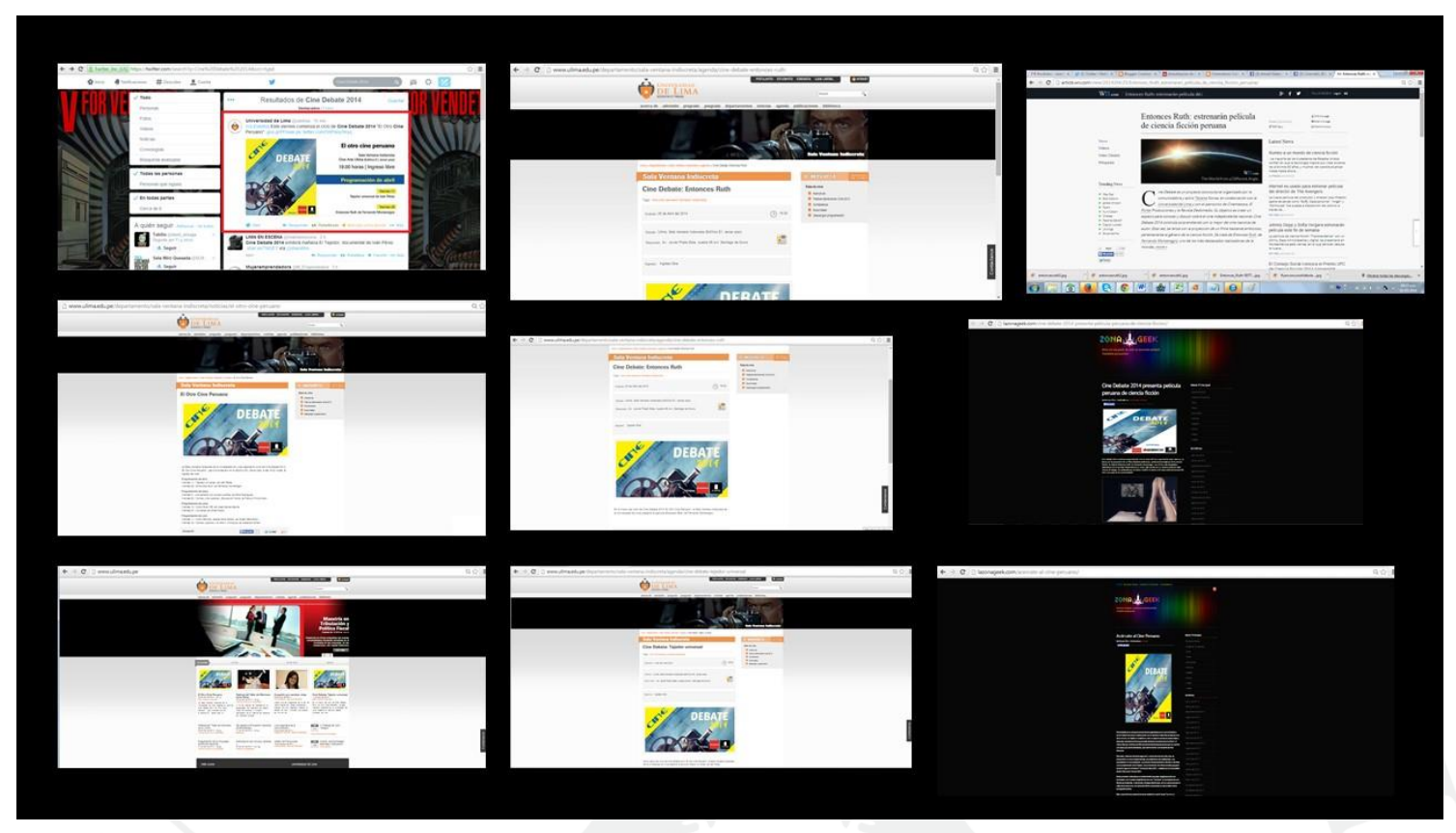

Collage de fotografías. Difusión de Cine Debate.

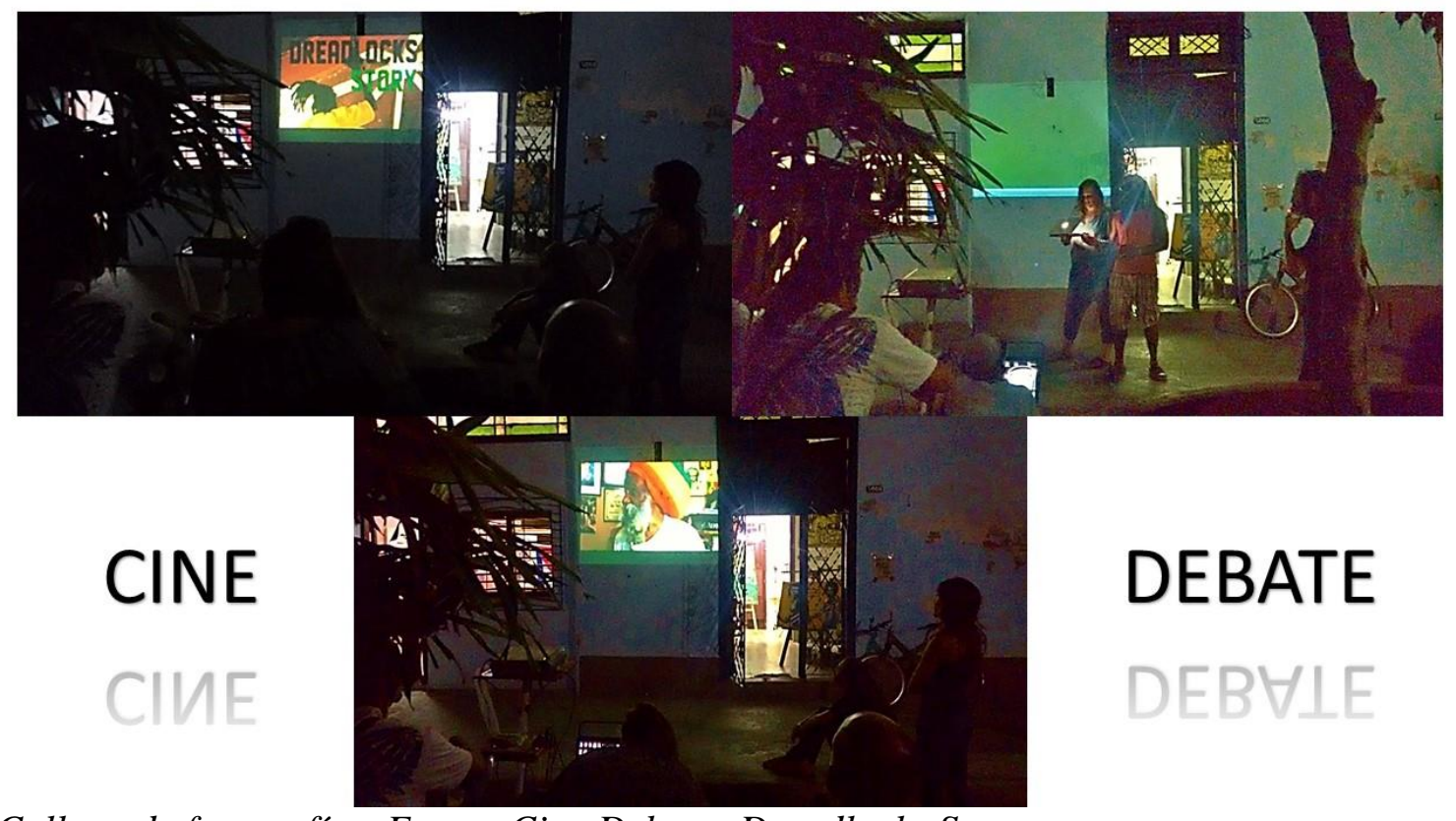

Collage de fotografías. Evento Cine Debate: Dreadlocks Story. 


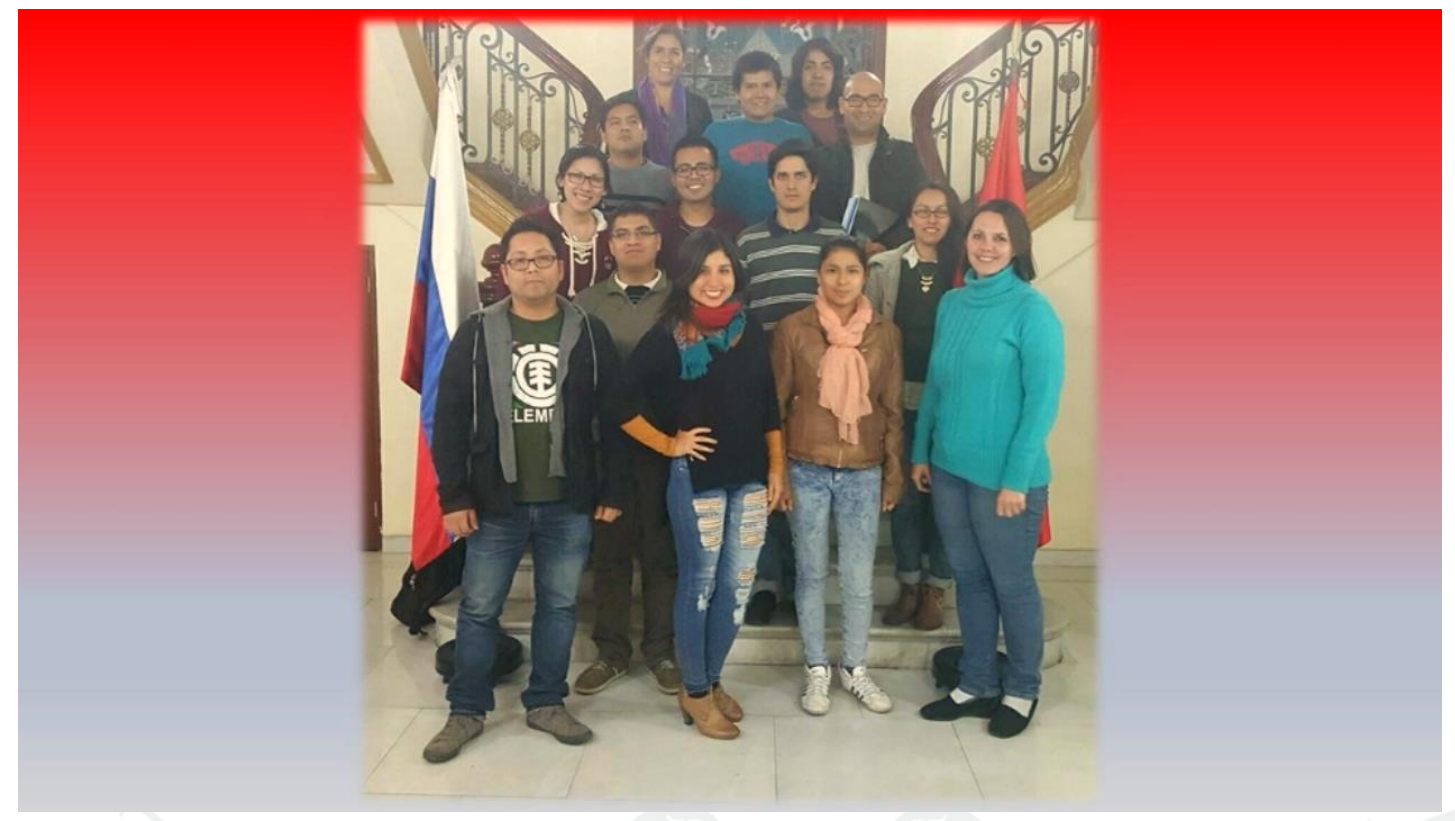

Equipo Cine Debate para la temporada noviembre 2017 en el Centro Cultural Ruso.

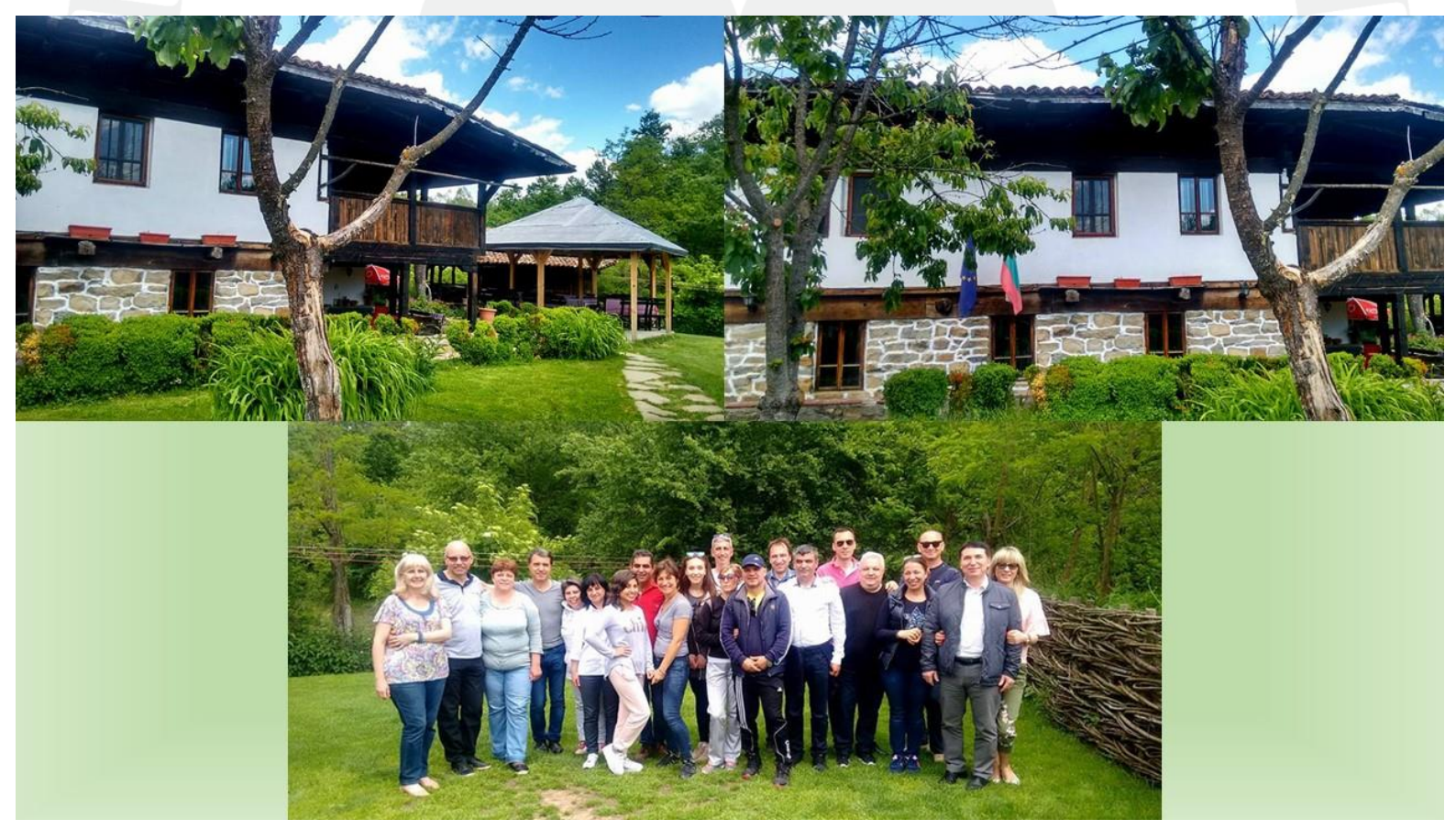

Collage de fotografías. Equipo Cine Debate para la temporada 2018 en la ciudad de Varna, Bulgaria. 
Anexo III: Vínculos en la plataforma web del proyecto Cine Debate

\section{FANPAGE}

https://www.facebook.com/pages/Cine-Debate/228782093978793

\section{PÁGINA WEB}

http://cinedebate12.wix.com/blog

\section{TWITTER}

https://twitter.com/cinedebate12

\section{VIMEO}

https://vimeo.com/user37279816

\section{YOUTUBE}

https://www.youtube.com/watch?v=2YEvdJSPaEA\&feature=youtu.be

\section{CORREO ELECTRÓNICO}

Cinedebate12@gmail.com 